Florida International University FIU Digital Commons

6-22-2018

\title{
Engineering Colonialism: Race, Class, and the Social History of Flood Control in Guyana
}

Joshua Mullenite

Florida International University, jmull031@fiu.edu

DOI: $10.25148 /$ etd.FIDC006833

Follow this and additional works at: https:// digitalcommons.fiu.edu/etd

Part of the Human Geography Commons, Nature and Society Relations Commons, Other International and Area Studies Commons, and the Social History Commons

\section{Recommended Citation}

Mullenite, Joshua, "Engineering Colonialism: Race, Class, and the Social History of Flood Control in Guyana" (2018). FIU Electronic Theses and Dissertations. 3800.

https://digitalcommons.fiu.edu/etd/3800 


\title{
FLORIDA INTERNATIONAL UNIVERSITY
}

\author{
Miami, Florida
}

\section{ENGINEERING COLONIALISM: RACE, CLASS, AND THE SOCIAL HISTORY OF FLOOD CONTROL IN GUYANA}

\author{
A dissertation submitted in partial fulfillment of the \\ requirements for the degree of \\ DOCTOR OF PHILOSOPHY \\ in \\ GLOBAL AND SOCIOCULTURAL STUDIES \\ by
}

Joshua M. Mullenite 
To: Dean John F. Stack, Jr.

Green School of International and Public Affairs

This dissertation, written by Joshua M. Mullenite, and entitled Engineering Colonialism: Race, Class, and the Social History of Flood Control in Guyana, having been approved in respect to style and intellectual content, is referred to you for judgment.

We have read this dissertation and recommend that it be approved.

Roderick Neumann

Percy Hintzen

Kevin Grove

Todd Crowl

Gail Hollander, Major Professor

Date of Defense: June 22, 2018

The dissertation of Joshua M. Mullenite is approved.

Dean John F. Stack, Jr. Green School of International and Public Affairs

Andrés G. Gil

Vice President for Research and Economic Development and Dean of the University Graduate School

Florida International University, 2018 


\section{ACKNOWLEDGMENTS}

Many thanks are due to my doctoral committee, Gail Hollander, Rod Neumann, Percy Hintzen, Kevin Grove, and Todd Crowl, all of whom provided important insights into the project at various points along the path to completion and I feel extremely privileged to have had such a wonderful dissertation committee. Though no longer at FIU, April Merleaux, Laura Ogden, and Caroline Faria each provided me with their own encouragement throughout my academic career that was vital to my growth as a researcher. April deserves special thanks as serving as a committee member for most my time in graduate school and shaping many of the historical aspects of this project.

Paul Losch of the Latin American Collection of the Smathers Library at the University of Florida and Carl van Ness of the University of Florida Archives also provided valuable assistance at various points during the writing and research phases of this dissertation, respectively. Paul's in-depth knowledge of the collection helped me find materials that I otherwise would not have seen. Though not featured in the dissertation, the materials curated by Carl in the preliminary stages of my dissertation research directly shaped the direction and outcome of my dissertation project.

I owe a great deal of gratitude to an uncountable number of colleagues in Guyana. There are too many friends to name individually, but I owe a tremendous debt to them all. I am particularly grateful to Moray House Trust who provided me with a venue and an audience with whom I could share portions of this research, make important connections to Guyana's civil engineering community, and receive invaluable feedback. Collis Augustine and Nikhil Ramkarran also provided me with great crash courses on life in Guyana that made my fieldwork relatively smooth and extremely productive. 
Various parts of this dissertation have been presented over the past several years at conferences around the world. I have a great deal of appreciation for my co-presenters and attendees who have offered me challenging questions and valuable insights that have made this work significantly stronger. Several of the ideas presented here also have their roots in publications submitted to and published in Geography Compass, Annals of the American Association of Geographers, Geoforum, Latin American and Caribbean Ethnic Studies, Human Geography, and Consilience: The Journal of Sustainable Development. The feedback of reviewers and editors for these publications has been invaluable and has had a direct impact on this dissertation.

This dissertation has been made possible in part by financial support from the Stephen J. Green School of International and Public Affairs at Florida International University through a Morris and Anita Broad Research Fellowship as well as a Doctoral Evidence Acquisition Fellowship and a Dissertation Year Fellowship from the University Graduate School at FIU. Additionally, the Department of Global and Sociocultural Studies, the College of Arts and Sciences (Now the College of Arts, Sciences, and Education), and the Graduate and Professional Student Committee at FIU have each provided me with travel funding associated with the conduct and presentation of this research at various times. The FIU Alumni Association supported me through a Panther Pride Scholarship in the fall of 2014 and the Phi Kappa Phi National Honor Society provided a Love of Learning Grant in the summer of 2016 that were essential to conducting preliminary research. 


\title{
ABSTRACT OF THE DISSERTATION \\ ENGINEERING COLONIALISM: RACE, CLASS, AND THE SOCIAL HISTORY OF FLOOD CONTROL IN GUYANA
}

by

\author{
Joshua M. Mullenite \\ Florida International University, 2018 \\ Miami, Florida \\ Professor Gail Hollander, Major Professor
}

Overabundance and scarcity of water are global concerns. Across the world's low-lying coastal plains, flooding brought on by sea level rise acts as an existential threat for a multitude of people and cultures while in desert (and increasingly non-desert) regions intensifying drought cycles do the same. In the decades to come, how people manage these threats will have important implications not only for individual and cultural survival, but also for questions of justice. Recent research on flooding and flood management probes the histories of survival, and adaptation in flood threatened regions for insights into emergent flood-related crises. However, scholars have thus far overemphasized the technical aspects of how engineered flood control systems functioned, overlooking both the specific social, political, and economic contexts within which past practices emerged and the social worlds that they helped create. This dissertation examines the social, economic, and political histories of flood control projects in the South American country of Guyana in order to understand the long lasting social, political, and environmental impacts of colonial-era projects. 
To do this, I utilized archival data collected from the National Archives in London, UK, historical newspaper articles collected through online newspaper databases, press release statements from Guyana's major political parties, and unstructured and semi-structured interviews with residents from coastal Guyana. These data were imported and analyzed using qualitative data analysis software in order to make connections across spatial and temporal scales.

The key finding of the dissertation is that, in Guyana, flood control engineering has historically played multiple social, political, and economic roles beyond the functional explanations assumed in many present environmental management discourses. Colonial engineering projects served as a way to protect colonizers from economic crises and social upheaval and were not just a means for protecting the coast from flooding. Additionally, the dissertation found that these projects were key to creating the racial geographies that helped to protect colonialism in its final years and which continue to shape coastal life today. Finally, the dissertation found that, after the end of colonialism, flood engineering projects were incorporated into larger projects of racialized regime survival. 


\section{TABLE OF CONTENTS}

CHAPTER

PAGE

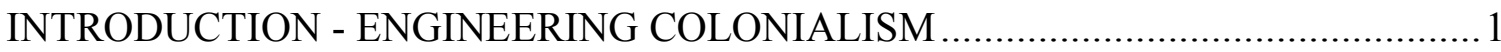

An Introduction to Coastal Guyana ................................................................ 3

Water and Water Management in Coastal Guyana and Beyond ......................... 8

The Political Ecology and Critical Physical Geography of Flooding................ 14

Historical Analysis and Socioecological Resilience.......................................... 16

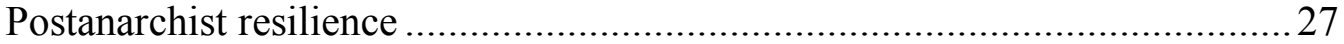

Flood Control Infrastructure as Imperial Ruins............................................... 33

Genealogies of Race and Infrastructure in Guyana ........................................34

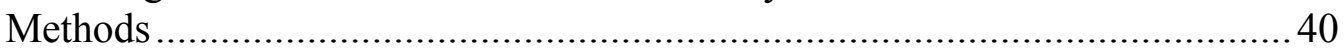

Organization of the Dissertation....................................................................... 43

CHAPTER 1 - THE PRECOLONIAL AND EARLY COLONIAL HISTORY OF

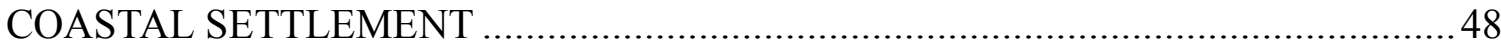

The Geophysical History of the Guiana Coast ..............................................52

Indigenous Land Settlement and Use ………............................................56

Amerindian Trade and the Beginnings of Guyanese Colonialism .....................6 61

Power, Politics, and the Taming of the Wild Coast ...........................................67 67

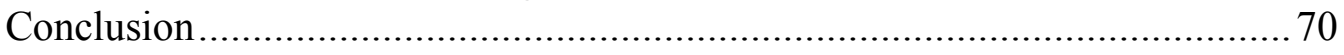

CHAPTER 2 - A MILD DESPOTISM OF SUGAR: RACE, LABOR, AND WATER

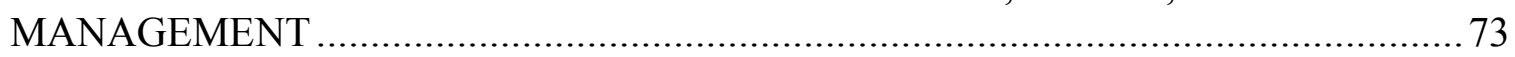

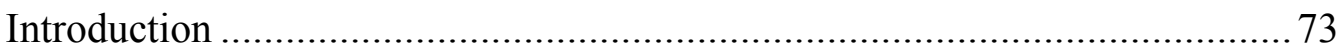

Infrastructure, Governance, and the Politics of Things ..................................78

Flooding, Labor, and the Sugar Industry in East Coast Demerara .................... 81

The Sugar Industry, Infrastructure, and Relief Works.....................................99

Conclusion: Sugar, Floods, and Reserve Armies of Labor ..............................99

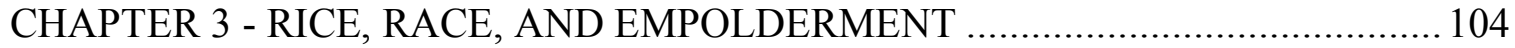

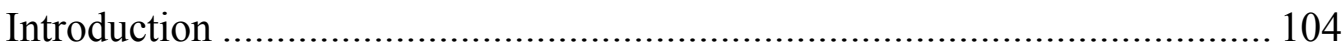

The Critical Physical Geographies of Empolderment ………….................... 113

Polders, Politics, and Agriculture ………………..................................... 118

Boeraserie and Black Bush Polder: Rice, Drainage, and Sea Defense ............ 126

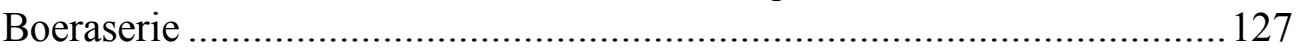

Black Bush Polder............................................................................. 130

Tapakuma: Race, Rice, and Foreign Aid in the Postcolonial Period............... 135

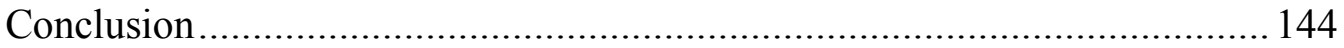

CHAPTER 4 - COLONIAL PERSISTENCE: RACE, CLASS, AND FLOOD CONTROL SINCE 1966 147

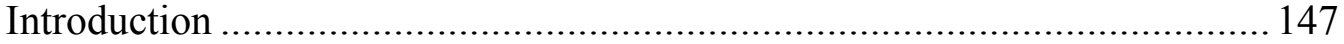

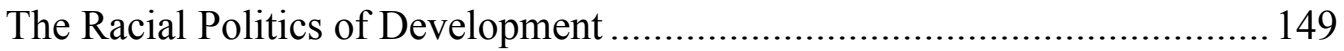


Understanding Modern Drainage and Irrigation Problems

CONCLUSION - COLONIAL RUINS AND THE CONSTRUCTION OF FLOOD VULNERABILITY: LESSONS FROM AND FOR GUYANA …………………….... 181

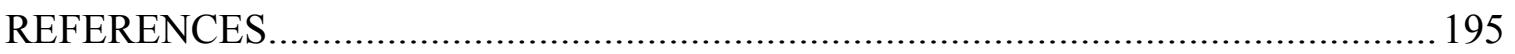

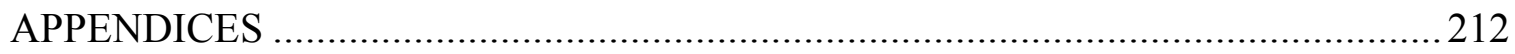

VITA 


\section{TABLE OF FIGURES}

FIGURE

PAGE

Figure 1 - 3D model showing the coastal plain from the Corentyne River (left) to the Essequibo River (right). Rendered by author.

Figure 2 - A typical plantation layout.

Figure 3 - Map showing the location of major drainage and irrigation projects in BG.. 112

Figure 4 -Rice Production by Acreage 1898-1968.

Figure 5 - The Real Meaning of Imperialist Aid. 151

Figure 6 - Extract from the January 24th, 1935 The Daily Argosy 183

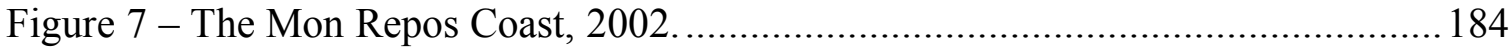

Figure 8 - The Mon Repos Coast, 2017. New housing highlighted.......................... 185 


\section{TABLE OF PLATES}

Plate 1 - The Sea Wall, ca. 1885 6

Plate 2 - Trash thrown between the seawall and mangroves at Beterverwagting............. 10

Plate 3 - Mangroves and Seawall in Beterverwagting, East Coast Demerara .................54

Plate 4 - Former cane fields now used for grazing in Den Amstel, Guyana .................. 109

Plate 5 - Former cane fields flattened and converted for rice production .................... 110

Plate 6 - "March past of settlers," Black Bush Polder Opening Ceremony.................... 132

Plate 7 - "Platform Party. Dr. Jagan Speaking." Black Bush Polder............................. 132

Plate 8 - "Mr. Benn, Minister, opening the Joppa sea sluice,” Black Bush Polder........ 133

Plate 9 - Ocean swells overtopping the sea wall, West Coast Demerara ...................... 173

Plate 10 - Billboard advocating for mangrove protection...................................... 178

Plate 11 - Flooding on Quamina Street, Georgetown............................................. 191 


\section{INTRODUCTION - ENGINEERING COLONIALISM}

\section{"Possibly the little already known may enable us to see farther into the darkness of the}

future, and to assist at events which are not yet. Possibly we may succeed in

contemplating in thought the spectacle of human history beyond the evil days of strife and ignorance, and there again behold the picture of grandeur and beauty already unfolded

by the earth." - Elisée Reclus, The Universal Geography, Vol. XIX (1876, vi)

Overabundance and scarcity of water are global concerns. Across the world's low-lying coastal plains, flooding brought on by sea level rise acts as an existential threat for a multitude of people and cultures while in desert (and increasingly non-desert) regions intensifying drought cycles do the same. In the decades to come, how people manage these threats will have important implications not only for individual and cultural survival, but also for questions of justice. Social, political, and economic conditions will play a vital role in the creation and continued engineering of water management schemes. As these schemes modify landscapes seeking to perfect them for particularly human ends, they will themselves become both reflective of and embedded in the social worlds that surround them (Geertz 1972). This is certainly the case in Guyana ${ }^{1}$, where long histories

${ }^{1}$ Throughout this dissertation, I use several names to refer to the same geographical region: the present-day country of Guyana. It was first established as four separate colonies by the Dutch. Essequibo and Pomeroon on the west, Demerara (or Demerary) in the center, and Berbice in the east. Pomeroon was never successfully colonized on its own and would later become a part of the colony of Essequibo. When the British took official control over the Dutch holdings in 1814, they combined Essequibo and Demerara 
of environmental engineering in the name of water management have thoroughly shaped and have been shaped by social relations in the country. This dissertation seeks to understand this relationship between infrastructure and the shaping of social conditions, looking in particular at the ways in which flood control infrastructure has been used as a form of governance in the South American country's low-lying coastal zone and the long-lasting impacts this has had on coastal socioecological resilience. In understanding governance, I draw on the late work of Michel Foucault. For Foucault $(1982,790)$, "[t]o govern $[\ldots]$ is to structure the possible actions of others." Beyond the function of government, which includes the official and institutionalized systems which define and enforce laws, taxes, etc. governance serves as a somewhat unofficial extension of this power into the practice of everyday life. Governance structures, rather than officially being officially codified or easily visible may serve as unseen extensions of broader systems of power. Generally speaking, this dissertation seeks to answer the question of how flood control infrastructure development, construction, and maintenance interact with the social formations of a given place, and in particular with the socio-geographical formations. How does this infrastructure work to shape the actions of free individuals through the delimitation of new social, political, and economic boundaries?

into a single colony which were united with Berbice in 1831 to become British Guiana. Throughout the text, I use each of these names when I am speaking specifically about the historical place. In 1966, British Guiana became the Commonwealth Realm of Guyana and in 1970 the Co-operative Republic of Guyana. I simply use Guyana to refer both the postcolonial configuration of the state (with no differentiation between Commonwealth Realm and Co-operative Republic) and to refer to the geographical area in a trans- or ahistorical manner. In cases where I am referring to the geographical area during the broad British colonial period, I use British Guiana. 


\section{An Introduction to Coastal Guyana}

Walking across the airport tarmac when I first arrived in Guyana I was greeted by the distinctive feeling of being in an amphibious landscape, one in which "across distinct geographical, social, political, and economic contexts, water and land enter in relational processes that have implications for the production of place" (Gagné and Rasmussen 2016, 135). Having grown up near the swamps, canals, and oceans that shape life in South Florida, it was a familiar sensation. The Cheddi Jagan International Airport, some 40 kilometers (around 25 miles) from Georgetown on the eastern bank of the Demerara River, is far removed both geographically and socially from the busy streets of Guyana's coastal capital, but the sense of the water from the unseen Demerara River nearby was still present. As we drove north along the river, down the poorly lit highway to our coastal destination of Ogle, in what are now the eastern suburbs of the capital city but which was at one time a thriving sugar plantation, my companion pointed out the sugar fields that lined the road to the east, and the kokers ${ }^{2}$ that helped drain and irrigate them to the west, both important parts of life in the country's coastal plain and highly visible indicators of the country's long colonial history. Regardless of the day of week, the

${ }^{2}$ Koker is an old Dutch term that has survived in Guyana from the Dutch colonial period but has little use anywhere else in the world. It refers to a type of flood gate which can be opened to flood a canal for irrigation purposes or to drain the canal when water levels are dangerously high. Sluice, a term for similar gates that came from the British and has wider international use is also sometimes used in Guyana. I generally use the term koker throughout this dissertation as this is the term most commonly used in my conversations in the country. 
sounds of music fill the air from the small rum shops and bars lining the East Bank Public Road as the taxis and minibuses dodge people and animals walking along the street.

When we approached Georgetown and the public road veered inland from the river, the fields gave way to factories, shops, and housing and the kokers became more frequent as we entered the highly-engineered landscape of the coast. Driving from the airport to the East Coast Demerara region - our final destination on that trip - requires traveling through Georgetown and, in particular, through the narrow streets sitting on either side of small canals that quickly fill with even the lightest rains. Knowing it was my first time in the country and owing to road work in preparation for the upcoming postcolonial jubilee celebrations, the taxi driver took us down South Road, where one of the few Dutch colonial-era drainage canals splits the east- and westbound corridors and down Camp Street in the Cummingsburg neighborhood, where a similar French-built canal had been filled in and replaced by a tree-lined avenue after the area's conversion from a sugar plantation to a colonial residential district.

As my taxi exited central Georgetown along the sea wall road that divides the city from the Atlantic Ocean, the unmistakable sensation of the ocean air and the sharp sound of crashing waves struck me. The road is nearly adjacent to the sea, but at high tide sits a few feet below it. In some places, people had parked their cars along the road to celebrate the weekend in the public spaces provided by the sea wall. In this Caribbean cultural tradition, called liming, the rum and beer flow freely as the sounds of Soca - a variation of calypso originating in Trinidad and Tobago that draws on musical styles from the many ethnic groups that occupy the Anglophone Caribbean - compete with the explosive sounds of ocean swells as they crashed against the rip-rap breakers a few feet away. Even 
prior to the end of colonialism, the sea wall served as a place of relaxation, where live music could be heard and the ocean breeze enjoyed (see Plate 1).

To the east, the roads cleared and the only thing visible along the sea wall was the spray of the ocean as waves collided with the modern concrete barrier built to prevent overtopping. The original sea wall, built between 1855 and 1874 after the devastating Great Kingston Flood of 1855 (see Chapter 2 - “A Mild Despotism of Sugar”: Race, Labor, and Water Management), is a sloping concrete structure built atop an earthen dam. The stepped façade on the oceanside combines with riprap to act as breakers, meant to keep the waves and their erosive actions at bay. Though once a dynamic site of coastal formation and erosion (see Chapter 1 - The Precolonial and Early Colonial History of Coastal Settlement), the sea wall ensures some measure of human control. As silting and accretion occurred, the waves began to break higher, forcing the postcolonial governments to erect an adjunct sea wall consisting primarily of precast concrete barricades atop the colonial structure (affectionately called "the toenails" by some of my Guyanese colleagues.) Despite these attempts to adapt infrastructure to new coastal realities, breaches and overtopping are still common, though now repaired much more quickly. During my time in the country, a sea wall breech that was inundating the East Coast Public Road was repaired within hours, a feat that would have been unheard of even a decade ago. 


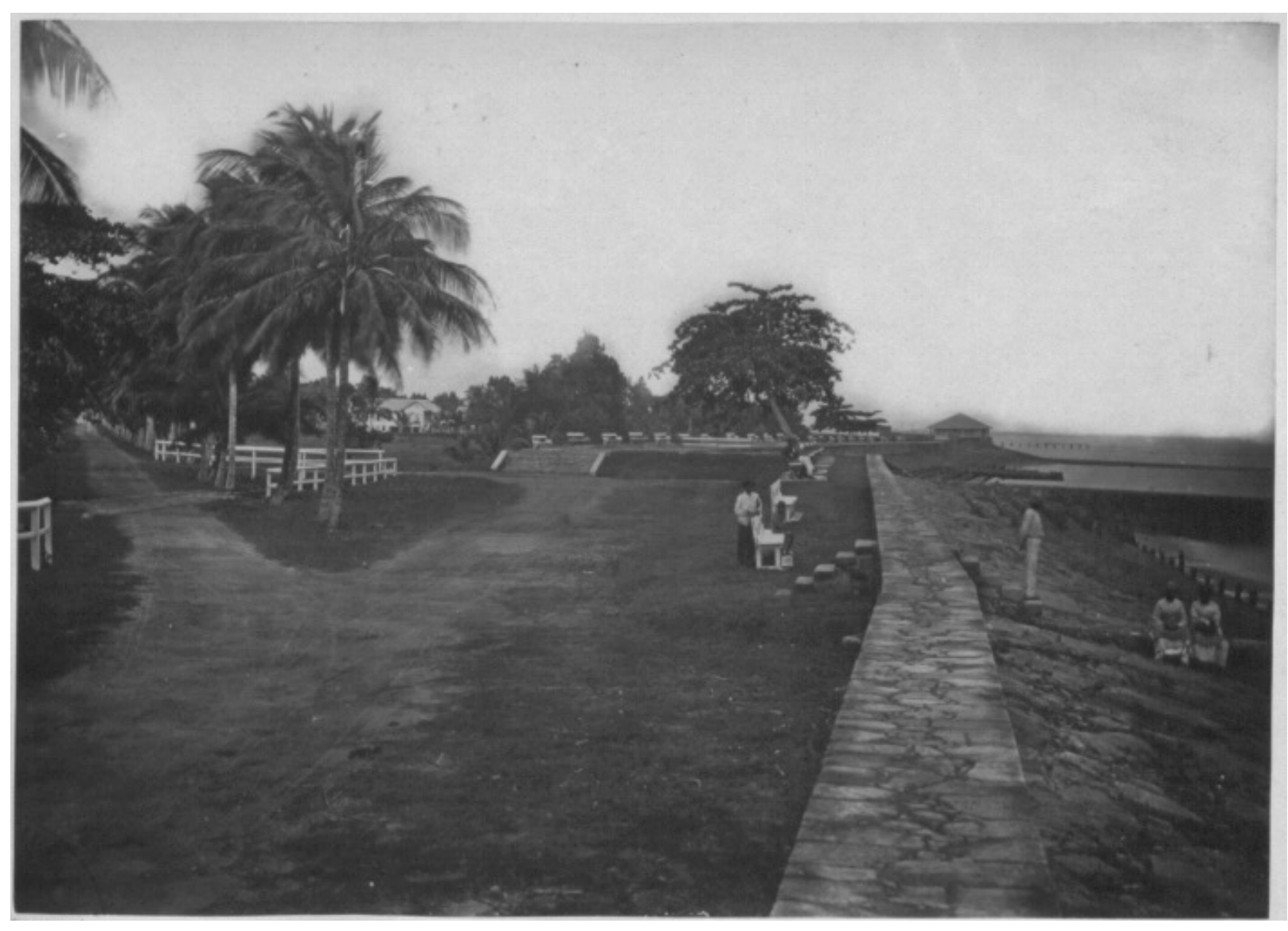

Plate 1 - The Sea Wall, ca. 1885. The portion in the photograph, about 150 yards from the "round house" remains a popular space for social activity. (The National Archives, UK CO 1069/355/6)

Beyond the apparently idyllic nature of this coastal scenery, Guyana's politics are deeply embedded within the fabric of these human-environment interactions. While I will provide details of the country's history and the development of at least some aspects of the political life of the coast in the chapters that follow, it is worth highlighting the modern racial-cultural geography as a means of situating and providing broader context for the region. Even during the short trip from the airport to Ogle, never leaving the greater Georgetown area, we passed through communities that were primarily Indo- 
Guyanese or Afro-Guyanese in both majority populations and culture. Within central Georgetown, the spatial segregation is less immediately obvious but can fall along class lines, with Indo-Guyanese, Portuguese-Guyanese, and Chinese-Guyanese populations owning a comparatively larger number of local businesses and Afro-Guyanese holding a larger number of laboring positions ${ }^{3}$. In the country more broadly, the segregation is even more pronounced with different ethnic groups populating different Neighborhood Democratic Councils (NDCs, the basic political body of local government.) With few exceptions, NDCs are run by representatives from one of the major political parties which, in the country's racially-bifurcated political landscape (see discussion in Chapter 4) align with the major racial-ethnic group represented in that NDC. In other words, most African-majority NDCs have local political representation from the African-majority political party while Indian-majority NDCs are represented by the Indian-majority party. Through the history outlined in this dissertation, the borders of the NDCs tend to fall along the boundaries of old plantations and thus along the lines created by water control infrastructure. Canals designed to prevent flooding or irrigate fields serve as effective racial-ethnic boundaries. While the boundaries are soft (i.e. people of all ethnic backgrounds can and do move freely between them) they provide discrete lines upon which locals understand the coast and to whom the government is expected to serve.

${ }^{3}$ In addition to the politically dominant Afro- and Indo-Guyanese populations, Georgetown also has a small Portuguese population and a growing Chinese population. These groups have historically served as population buffers between the majority populations of Afro and Indo-Guyanese and the white settler population, but more recently have come to dominate certain sectors of the economy, particularly grocery stores. 
Colonial-era stereotypes of African villages as being violent, fecund, or otherwise "wild" persist in the postcolonial imagination and I was often warned not the enter them alone, although I never felt less safe than anywhere else in the country and at times, especially in the East Coast Demerara region the borders between African and Indian-majority areas are fuzzy at best. One goal of this dissertation is to better understand the origins of this geography as well as the ways in which flood control infrastructure projects have been used to create and reinforce it.

\section{Water and Water Management in Coastal Guyana and Beyond}

In concert with this racial cultural geography, water is an everyday part of the experience of coastal Guyana. As much as 90 percent of the country's population lives along the coast, the majority of which sits below sea level. In the environs of the capital city and its surrounding suburbs, a network of canals, ditches, and open pits work in conjunction with earthen dams, concrete sea walls, engineered groins, riprap, modern mechanical pumps, $18^{\text {th }}$ and $19^{\text {th }}$ century floodgates, and more recently dense mangrove forests in an attempt to delineate the boundaries between the wet and the dry. In the villages that extend outward along the sea or down the banks and across the deltas of one of the country's many rivers, the struggle with water is no less quotidian. As agricultural spaces, they have unique water needs in addition to protection from the encroaching tide or the river flood. In these spaces, the needs for drainage and irrigation infrastructure to support the agrarian coastal economy interact and conflict with the massive inequalities of postcolonial life through processes that Sara Pritchard (2012) refers to as "hydroimperialism" and "hydrocapitalism." These describe "the ways that water, 
hydraulic knowledge, and water management practices both revealed and reproduced unequal power relations predicated upon an expansionist mentalité, whether political or economic in orientation" as well as "how particular hydraulic knowledge systems and management regimes reflected and realized capitalist relations," deepening the already uneven political economies in place as a result of colonialism and extending them into the present (Pritchard 2012, 592).

This political economy of water management has played out in a variety of highly visible ways in the postcolonial history of Guyana. A widespread lack of affordable housing and a coastal economy tied to a dying agricultural industry have given rise to a large population of homeless and squatters, often living on marginal and flood prone lands (see Pelling 1999, Chapter 4 - Colonial Persistence: Race, Class, and Flood Control Since 1966). Recent cases of squatting in the southern edges of Georgetown have directly interacted with flood management practices as squatters in South Ruimveldt build their houses along the banks of drainage canals, making it difficult (if not impossible) for dredges to pass through them and clear them of debris. This exacerbates already severe local flooding with squatters feeling to worst impacts of it both in terms of their proximity to flood waters and the disruptions they experience in their everyday lives. Besides squatting, throughout the country, the inflated costs of garbage disposal in certain areas and the impassibility of certain village roads after heavy rains in others means that drainage and irrigation canals, water conservancies, and mangrove forests become dumping grounds for everyday refuse, clogging drainage outflows and increasing the impacts of floods (see Thom 2011; Plate 2; Chapter 4 - Colonial Persistence: Race, Class, and Flood Control Since 1966). If there is an inequality of experiences of flooding along 
political economic lines, what about racial or ethnic lines? How do race and class unite and collide with the engineered coastal landscape? Besides generalized notions of neocolonialism or late capitalism, what are the political economies at work in such a complex socioecological system? What social desires and imaginaries clash within it? Perhaps most importantly, how did this system come to exist as it does?

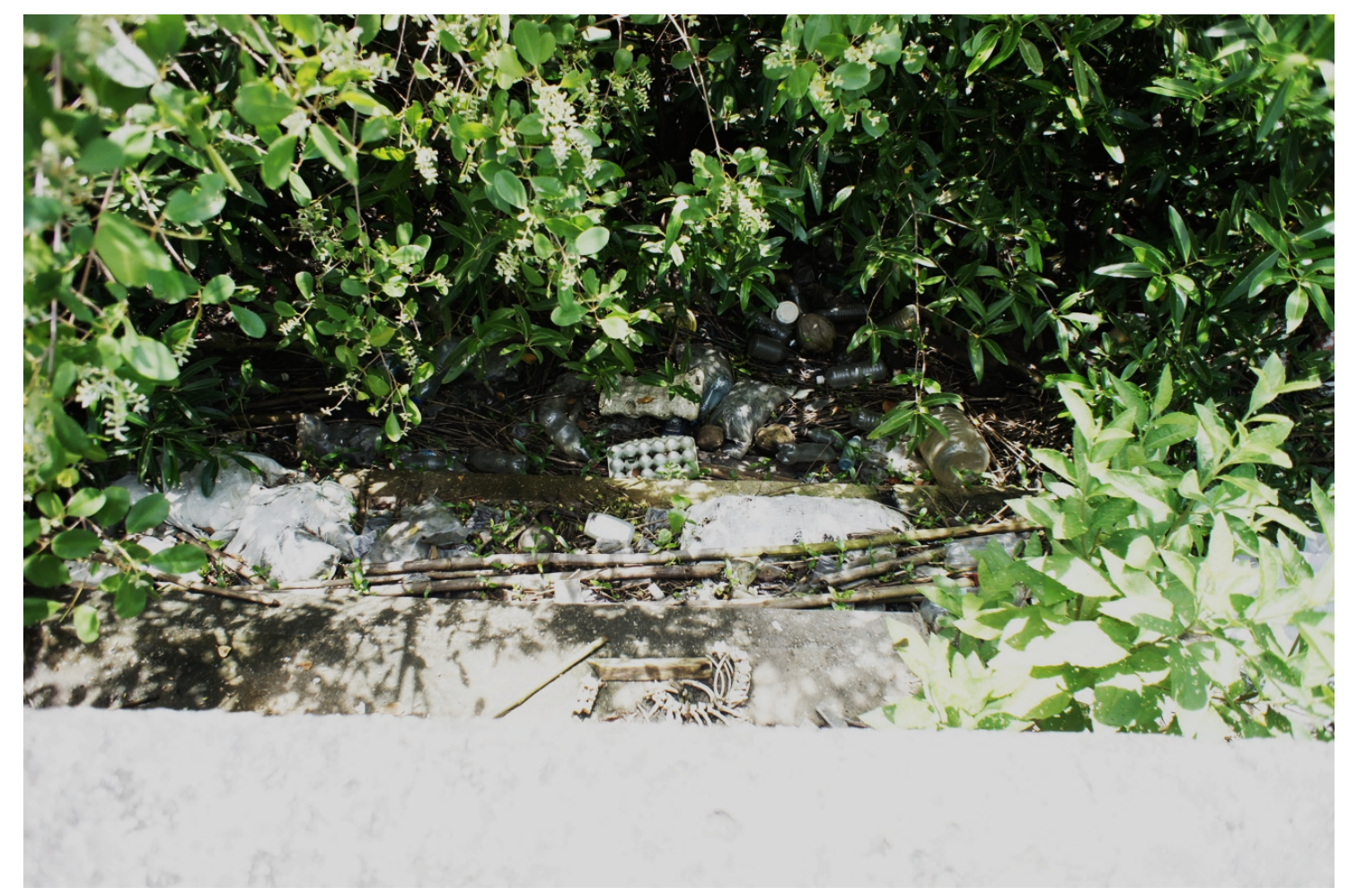

Plate 2 - Trash thrown between the seawall and mangroves at Beterverwagting (Personal photo, 1 July 2016)

Beyond Guyana, coastal flooding represents one of the most significant challenges facing the world today. Coastal zones are currently more populated, are experiencing higher rates of population growth, and are urbanizing more rapidly than 
their hinterland counterparts and show no signs of slowing (Neumann et al. 2015). The high population density and rapid population growth in coastal areas indicates that sea level rise will combine with other sources of coastal flooding in ways that have the potential to displace hundreds of millions of people and have significant impacts in the global economy over the next century, with the effects being unevenly experienced in the developing world (see Dasgupta et al. 2009). To address this threat, a renewed critical and historical interest in flood management practices and flood control infrastructure systems that are meant to mitigate the impacts of sea level rise has emerged in order to provide the tools necessary for facing these uncertain environmental futures (Gersonius et al. 2013; Hill 2015). This recent research on flooding and flood management probes the histories of resilience, survival, and adaptation in flood threatened regions for insights into emergent flood-related crises (e.g. Castonguay 2007; Hill 2015; Shrubsole 2007; Wesselink 2007). However, scholars looking at the past to find solutions for contemporary environmental concerns have tended to overemphasize the technical aspects of how engineered flood management systems functioned, overlooking both the specific social, political, and economic contexts within which past practices emerged and the social worlds that they helped create. These oversights create the potential for environmental futures that perpetuate the unjust social conditions of the past and present, leaving marginalized people vulnerable (Ranganathan 2015).

One crucial concern missing from these analyses is that infrastructural works such as roads, bridges, power grids, communications networks, and the dykes, dams, levees, and sea walls that make up flood management systems can have both intentional and unintended political effects resulting from the way they are designed and built, prior to 
any of their stated or implied technical goals (Winner 1986; Mitchell 2002). Political ecologists have begun to argue that infrastructure networks extend beyond just the items built by humans to make trade, transportation, and communication easier but also to the natural systems which those social tools rely on (Carse 2014). These broad networks of human, natural, and hybrid systems broker state power, defining the ways in which the state can enter everyday life and in turn shape the possibilities of life around the goals of the state (Meehan 2014). Thus, in the Foucauldian sense outlined above, the networks of infrastructure that make up everyday life are in themselves modes of government. Rather than being subscribed to and tools for some external governmentality, these systems are extensions of governmental power.

Recognizing that flood management projects rely on networks of infrastructure that are imbued with political, economic, and social objectives, this dissertation uses a case study of the ways in which Guyana's colonial politics are both expressed in and (re)produced by flood management projects in order to understand the sociality of infrastructure and the resilient political and economic commitments of colonialism which are implicated within it. Through an examination of the environmental history and political ecology of flooding and flood management in coastal Guyana, I focus on the ways in which colonial processes of racialization shaped the design and implementation of flood control infrastructure, how racial categories were shaped and reshaped by this infrastructure, and how flood infrastructure provides a space for the persistence of colonial racialized social and environmental practices into the present through the postcolonial persistence of colonial formations. In this way, I argue that Guyana's flood management infrastructure served as both an active form of governance in the present as 
well as way means for ensuring the and governing the future by forever limiting the possibilities of coastal life.

Utilizing a combination of archival research and in depth, semi-structured interviews (see on page 34), this dissertation also seeks to understand the ways in which, beyond protecting the coast from flooding, infrastructure acts as a way of reinforcing the power of the white supremacist colonial state and to understand how, like colonial laws, customs, and economies, environmental engineering continues to shape the boundaries of possibility for postcolonial life. I draw on theoretical interventions from human geography, anthropology, science technology studies, environmental history, and other disciplines to understand Guyana's flood management system, and the broader water management system it is intimately a part of, as a form of colonial governance, what has been called 'colonial hydrology' (D’Souza 2006; see also Pritchard 2011). My primary argument is that, in their attempts to engineer the environment in such a way as to reduce the risk of catastrophic flooding of agricultural lands, colonial administrators were simultaneously and actively engineering the social life of the colony. In this postcolonial period, these water management projects became tied to other colonial legacies including the racial politics of the postcolonial state and the new-found desires for regime survival embedded within it (see Hintzen 1989). In this way, water management projects are not just ways of protecting people or land from the threat of flooding or to provide insurance to agricultural sectors, but instead act as an extension of the colonial government itself, acting as a silent and omnipresent enforcer of colonial politics, including those which limit the ability of individuals to prepare for and respond to environmental harms in the present (cf. Pritchard 2011). I trace this governance through colonial processes of 
racialization, class formation, and the agrarian economies that bolstered the colonial endeavor in the Caribbean.

\section{The Political Ecology and Critical Physical Geography of Flooding}

On May 16, 1895, a letter in the Daily Chronicle titled “Is the Long Sleep Over?" called British Guiana "a tropical Holland." The comparison - relating to the sub-sea level nature of the colony's most densely populated region as well as the systems of infrastructure which protect and drain it - is in some ways an apt one, though perhaps incomplete. It need not be said, either now or in 1895, that Georgetown is not Amsterdam, and that the flood control infrastructure existing between the two may be the extent of their similarities. However, with sea level rise providing a simultaneous rise of the Dutch as the global experts in coastal water engineering, the comparison serves as a useful tool for understanding the ways in which different political and economic conditions shape experiences with flooding. It is also a useful comparison because much of the groundwork for Guyana's flood infrastructure was laid during the Dutch colonial period, even if not actually built by the Dutch themselves (as detailed in Chapter 1 - The Precolonial and Early Colonial History of Coastal Settlement.) In a recent New York Times article, Arnoud Molenaar, then the chief resilience officer for the Dutch city of Rotterdam, stated that "Water managers were the first rulers of the land. Designing the city [of Rotterdam] to deal with water was the first task of survival" and was a task that is always in process (Kimmelman 2017). But we might ask in response, "the survival of what?" What sorts of politics are at stake within a rule of water management? What kinds of political, economic, and social motivations underlie these politics? What forms of 
injustice are created or perpetuated through such a regime? Such questions can be answered through an engagement with the fields of political ecology and critical physical geography.

Emerging from critical examinations of disasters in both geography and development studies, political ecological analysis has suggested that there are political, economic, and social factors that must be considered in attempts to understand the drivers behind changing environments, upsetting the distinction between "natural" and "artificial" ecological phenomena. The ways in which people responded to environmental change, whether through the long-term effects of a process like desertification or in the recovery period after a particularly bad flood, earthquake, or some other natural event was becoming an important part of development planning (Wisner et al 2004). From its inception as a discrete body of literature, political ecology has been concerned with, among other things, the ways in which apolitical ecological discourses of adaptation and maladaptation to environmental change were deployed in policy as a means of reducing vulnerability to environmental hazards and change (Neumann 2005; Watts 2015). Rather than address these issues at their root, however, mainstream socioecological analysis and environmental policy focused instead of the actions of individuals, ignoring the context within which these actions occurred (Blaikie 1985; Blaikie and Brookfield 1987). Thus, actions that appeared irrational or downright harmful were instead responses to a broad set of conditions which limited individual possibilities. 
Critical physical geography takes this analysis a step further. It argues that, beyond political and economic inequalities operating at the interface of people and the environments in which they live, it extends to the very geophysical nature of the land (Lave et al. 2014). In this way, it is not just floods, droughts, or famines that are caused at the root level by inequality, but the very geophysical processes which occur in place. As demonstrated throughout this dissertation, in Guyana this means not only do the floods experienced along the coast have political and economic origins, but so do the very meandering of the country's river and the processes of sedimentation, accretion, and erosion that occur along the sea.

\section{Historical Analysis and Socioecological Resilience}

Over the past three decades, there has been something of a paradigm shift in the field of ecology as well as in environmental studies more broadly that has impacted the way flood vulnerability is conceptualized. While political ecology critiqued the apolitical nature of ecological analysis applied to social systems, a new form of ecology was emerging which saw adaptation as taking place within a larger field of instability, where different threats were managed and negotiated in a broader plane and in such a way that, without the influence of powerful external factors, emergent forms of coping develop and create resilient systems capable of withstanding a variety of everyday threats. If plants, non-human animals, and entire ecosystems can be resilient, then why not people? Over the past decade, a new form of mainstream socioecological scholarship has developed which seeks to understand the ways in which humans work collectively to account for a variety of social, political, economic, and environmental information in order to better 
withstand potential threats to their environments. Vulnerability, in this new sense, occurs when some people are unable to account for some threatening force and thus fail to be resilient. However, it is only recently that the topic has been approached within the geography literature. A Web of Science citation report of geography journals shows less than 50 references to the concept in 2005 and nearly 500 in 2015 . The rapid growth of resilience as a model for understanding a variety of social and environmental problems has become a cause for concern for many geographers and those in allied fields, with many uneasy with the ease with which resilience is tied to neoliberal development practices (e.g. Evans and Reid 2013; Chandler 2014; Welsh 2014). This is particularly true in the interdisciplinary subfield of political ecology, where anxieties over resilience are tied to a broader concern with approaches to development and risk reduction that fail to address the causes of poverty and vulnerability (Bryant 1997; Taylor 2015; Watts 2015). Disaster scholars more broadly see promise offered by resilience, but only if inequalities are addressed in its formulation (e.g. Canon and Müller-Mahn 2010; Tierney 2014). This latter work is in line with resilience scholarship that looks to political ecology as a means of better understanding the operation of power in socioecological systems (Fabinyi, Evans, and Foale 2014; Ingalls and Stedman 2016).

In the time since the ecological concept of resilience developed in the early 1970s, it has become a normative model for environmental and economic policy and a key tool for governance in a complex world with an uncertain future (Aradau 2014; Welsh 2014). If humans are part of complex socioecological systems, catastrophes that disrupt human life carry the potential to cause a disruption that cannot be recovered from. Since 
catastrophe can occur anywhere at any time, risk reduction has been incorporated into people's most banal practices (Aradau and Van Munster 2011). Resilience offers policymakers the opportunity to promise a new vision of security in an unknown, at risk future (Aradau 2014). The result of this understanding of resilience as part of everyday life always already at risk has resulted in new theorizing about how to build or promote resilient communities that must deal with environmental change and disasters (e.g. Aldrich 2012; Walker and Salt 2012; Washburn 2013; Rodin 2014; Tierney 2014; Biggs, Schüller, and Schoon 2015). Resilience has likewise been used to inform new approaches to sustainable development in order to address the general vulnerability experienced in less developed countries (Handmer and Dovers 1996; Folke et al. 2002; Brand 2009).

The quick adaptation of resilience by geographers and those working in related disciplines is not entirely surprising. Kevin Grove $(2018,15)$ argues that "the roots of resilience can, to a surprising and largely under-acknowledged extent, be traced back to earlier scholarly efforts to grapple with humans' fundamental creativity and unpredictability in a complex and indeterminate world lacking transcendental guarantees." However, the recent upsurge of resilience as a foundational concept in multiple policy realms has drawn the attention of a number of critics who point to the discursive strategies of resilience planning to promote certain political economic goals that they see as detrimental to the continuation of life on earth (Welsh 2014). Drawing largely on the theoretical insights of the later work of Michel Foucault, these scholars argue that resilience discourses produce a new regime of truth in which the antithesis to vulnerability is the ability of the individual to remain useful participants in a capitalist 
system with the least amount of reliance and input from the state. In this manifestation, resilience becomes a way of refusing the protections that the liberal state has long promised and instead shifted the burden on the private industries which require resilience projects be profitable. For these critics, resilience represents acquiescence to neoliberal capitalism, acceptance of a maintenance role in a system supported by mass inequality rather than resistance, and a need only to adapt to the vulnerability experienced in everyday life rather than attempting to eliminate it altogether (Walker and Cooper 2011; Evans and Reid 2013; Aradau 2014; Chandler 2014; Welsh 2014). Jeremy Cooper and Melinda Walker (2011) find this aspect of resilience to be a part of its origin story. They link the development of resilience in ecology with the rise in popularity of the economic work of Friedrich Hayek, arguing that a focus on the resilience of a system to absorb disturbance fits neatly within economic concepts that are similarly subject to shifts, disturbances, and potentially disastrous scenarios but which, over a long enough period, maintain their desired function. David Chandler (2014) takes a slightly different approach, arguing that as the idea of resilience developed it began to incorporate and respond to a number of political economic criticisms that were being leveled against the authoritarian tendencies of both capitalism and the state. Socioecological systems thus incorporate a political economy based on the ability of the system to organize itself in complex ways. By guiding this self-organization toward systematic resilience it can now be seen as a way of preventing the existing system from changing, thus maintaining the political economic status quo (Evans and Reid 2013). 
Embedded within this concept of socioecological resilience is a reliance on environmental history that has gone largely unexamined. While this new focus on inherently unstable and emergent systems reflects social scientific understandings of complex socioecological relationships, work that looks at resilience has largely failed to address the ways in which past shifts continue to shape the possibilities for future outcomes. One of the sites in which this is most visible is in projects of environmental restoration meant to increase resilience, where it might be worthwhile to ask to what state exactly is the environment being restored and for what ends? ${ }^{4}$ The authors in a fairly recent volume, edited by Allen Thompson and Jeremy Bendik-Keymer (2012), take up the argument that not only should adaptation be the norm, but that it ought to be done in ways that are ethical to human and natural worlds. The authors take adaptation to be a type of mitigation for future catastrophic events. Adaptation, for them, is then a way not only to adjust individual practices in everyday life to the reality of a volatile environment, but a way of changing human-environment relations to reduce future impacts. However, past decisions are not equally seen as structuring. Instead, the past is treated as a given point with only a few possible options which are treated as being inevitable outcomes broader conditions rather than contingent outcomes of larger social processes. The extent of history thus exists only in as far as scholars consider the historical fidelity of the land to be restored (even if climate change means we can never truly restore it to how it once

${ }^{4}$ There are several chapters on environmental restoration, its ethical considerations, and the politics embedded within restoration projects in Thompson and Bendik-Keymer 2012. I have situated this work within a broader context of climate adaptation and resilience in Mullenite 2017. 
was). Once "restored," human-environment relations must take a new form that does not continue the violent exploitation of resources that caused the present problems. This is because, while positive, restoration is ultimately a type of reparation or restitution that require existing negative practices to exist. Restoration, then, is a one-time goal that must coincide with new ways of interacting with the environment. In these new interactions, we use the past not as a reference point for restoration goals or a source of environmental harms but as a way of finding what it is we desire about past environments. I address this to some degree in Chapter 4 - Colonial Persistence: Race, Class, and Flood Control Since 1966 but the entirety of this dissertation might be seen as a response to these somewhat ahistorical or partially-historical approaches to environmental change. I argue throughout this dissertation that human action on or toward the environment creates a variety of social, economic, political, and even geophysical options while simultaneously foreclosing on other possibilities and thus shaping the grounds on which resilience is both understood and through which it might be realized. By treating resilience as ahistorical or only quasi-historical, the broader conditions of life through which individual decisions are made and their lasting impacts are ignored. Instead, socioecological resilience (in some form or another, see Grove 2018 for discussion of the multiplicity of forms) is an emergent character of social life which can flourish in some conditions and falter in others, with the latter case creating a multitude of potential issues for (re)building resilience later. A defeatist response might say that those possibilities for resilience are long gone, but as ecologists and engineers work to manage and restore coastal environments it is worth asking, what kinds of pasts and futures are they creating? 
The ahistoric nature of resilience is not its only fault. As it has become more popular as a paradigm within environmental management and ecology more broadly, resilience has also developed a growing number of critics. Michael Watts, for example, has called resilience "old wine in new bottles," arguing that resilience is not so much a paradigm shift in ecological thinking as it is a way of repackaging old ideas of adaptation and maladaptation into a new form (Watts 2015). Drawing on Pelling (2011) and Cote and Nightingale (2012), he notes how the malleability of resilience makes the principle of adaptation difficult to get a firm grasp on in this context (see also Anderson 2015). However, he does see similarity between works on resilience and the normative character of cultural ecology that political ecology sought from the outset to address (Watts 2015). Thus, while not identical, earlier appeals adaptation and recent calls for increased resilience serve similar functions in policy discourses. For Watts (2015), an important difference arises in the way that resilience and its correlated principles function as a form of biopolitics expressed in the administration and regulation of life processes. Here, Watts agrees with a number of critics who focus on the ways resilience is used to govern and secure everyday life (Walker and Cooper 2011; Evans and Reid 2014; Grove 2014a; 2014b). Because resilience focuses on the capacity of individuals to absorb shocks without changing form or to recover from them and return to their previous state, potentially stronger, disasters and vulnerability remain inevitable characteristics of the resilience literature (see also Evans and Reid 2014). If resilience represents a way of living with rather than reducing the risk of disasters, then the normative differences that make resilience thinking incompatible with political ecology become clearer. 
Matt Turner (2014) links the rise of political ecology as a field of inquiry and resilience-thinking in ecology to a mutual aversion to equilibrium approaches that could not stand up to empirical, field-based evidence (see also Holling 1973; Neumann 2005; Watts 2015). For Turner, one of the major differences between political ecology and resilience approaches is in the normative commitments of each, with resilience scholars largely missing broader systems of injustice by focusing primarily on the actions of individuals. This leaves the potential for violent, vulnerability-producing institutions to remain intact. An example of this can be seen in earlier work done by Garry Peterson (2000) who argues that resilience offers a way of including more ecological analysis in political ecology while political ecology can bring a stronger focus on political economy in work on resilience. In his case of the political ecology of salmon in the Columbia River Basin, however, he shows why the marriage of the two fields is difficult despite their overlap. Peterson is concerned with a variety of multi-scalar human actions that shape the ecology of the basin, potentially reducing the resilience of both human and non-human life in the area. In doing this he overlooks the political economic causes of changes in land use that decrease resilience (cf. Taylor 2015). This is in part because the normative goals of resilience approaches, even when they attempt to make explicit the role of political economy in environmental change like Peterson's, are different than those of vulnerability and political ecology-based approaches. In the case of the Columbia River Basin, Peterson (2000) suggests changes in the form of governance of water rights so that it includes a larger number of voices combined with legal structures that prevent the wielding the political and economic power of one group over another. While such changes are certainly agreeable to a political ecology approach, they do not 
go far enough as they leave in place the political and economic systems that lead to a lack of resilience in the first place (cf. Turner 2014; Taylor 2015).

The differences between Peterson's (2000) and political ecological readings of environmental problems, social change, and the potential for meaningful change highlight the apparent incommensurability of the approaches. This is due in part to the fact that Peterson's attempt to reconcile the fields does not account for what Antonio Ioris (2014) calls the "political ecology of the state." Ioris argues that the "historical role and class commitments" of the state are fundamentally at odds with genuine desires for ecosystem protection (Ioris 2014, viii). This is because the state exists as a way of ordering the world for the expansion of capitalist accumulation processes at the expense of the environment even when policies are enacted that are ostensibly meant to protect the environment (Ioris 2014). The role of the state as an ordering force for the expansion and continuation of capital accumulation, even if such an approach contradicts other proposed goals of the state such as environmental and livelihood protections, must be accounted for. This is particularly true when such ordering has the direct effect of reducing resilience (Taylor 2015). Who is able to make environmental decisions, based on what knowledge, and to what ends are key questions asked by political ecologists in order to recognize the operation of power within socioecological systems (Bryant 1997). Such an approach is not yet matched in the resilience literature which has thus far had only limited engagement with the operations of power behind the way decisions are made (Ingalls and Stedman 2016). 
One of the key points of contention between political ecology and resilience approaches to environmental problems lie in the way each recognize questions of power (Ingalls and Stedman 2016). Understanding how relations of power operate and the ways in which this operation impacts socioecological systems is a defining characteristic of political ecology (Bryant 1997). From its inception, political ecology has set itself apart from other approaches to social and the environmental issues through a focus on the root rather than proximate causes of these issues. Raymond Bryant (1997) has traced this through the introduction of the sustainable development paradigm and its inability to adequately address either social or environmental concerns. Because it is poverty, and not the causes of poverty (i.e., unequal relations of power in a capitalist political economy) that are tied to environmental degradation, superficial efforts at poverty alleviation that leave in place the conditioning factors that produce poverty in the first place cannot adequately speak to environmental issues (Bryant 1997; Neumann 2005; Watts 2015; see also Watts 1983; Blaikie 1985; Blaikie and Brookfield 1987). Political ecology addresses this shortcoming by recognizing that "the relationship between actors $[\ldots]$ and the links between actors and the physical environment, are conditioned by power relations" (Bryant 1997, 10). It is the inequality of actors in these power relations that must be understood and addressed if environmental problems are to be addressed effectively (Bryant 1997).

Recent scholarship in resilience has attempted to overcome resilience's lack of an analysis of power (Fabinyi, Evans, and Foale 2014; Boonstra 2016; Ingalls and Stedman 2016). Thus far, these approaches have taken political ecology's critique seriously. 
Michael Fabinyi and colleagues (2014) seek to understand power in resilience scholarship through an expansion of the "social" character of social-ecological systems. In particular, they focus on the ways in which differentiated social desires and relations of power are conceptualized in anthropology and political ecology, respectively. They argue that while resilience is itself inherently value neutral, it is treated primarily as a positive condition of socioecological systems with little focus on the resilience of pathological social relationships (such as poverty and general social inequality.) They argue that, while resilience approaches have attempted to account for material operations of power, they fail to account for the discursive potential for power that arose in later, explicitly poststructuralist approaches to political ecology (e.g. Tsing 2005; Li 2007; Escobar 2008). Because resilience does not account for the ability of power to circulate through particular discourses, even when it looks at the role of knowledge in producing resilient socioecological systems, it fails to understand much of the context that shapes and reshapes environmental models, assuming them to be relatively static and power neutral (Fabinyi, Evans, and Foale 2014; see also Cote and Nightingale 2012).

Wiebren Boonstra (2016) has noted that other social scientists, including political ecologists, have reasons for understanding power that move beyond clarification and better measurement of an ecosystems potential for resilience, including understanding "the extent to which systems and institutions help people in societies to meet their needs and wants, free from the power of others" (Boonstra 2016, 2). However, this is often antithetical to the ways in which resilience is enacted in policy. David Chandler (2014) has argued that the approach taken in resilience scholarship to understand the relationship 
between actors forecloses on the possibility of problems being assigned to any particular cause due to vulnerability's nonpoint origin, a fact conceded to some degree by Boonstra (2016). However, while direct causal relationships cannot be traced due to the epistemology on which resilience is founded, there is a need to recognize the indirect responsibility for actions that cause negative socioecological impacts (Chandler 2014; Boonstra 2016). To assign some level of responsibility, Boonstra (2016) argues for a focus on power that looks not for particular individuals but instead at the ability of individuals and groups to shape social relationships in ways that cause resilience to be reduced. This analysis of power thus doesn't require individuals be blamed or held liable but does recognize that the actions of individuals are not equally powerful in a socioecological system. While a useful addition to the resilience literature, this conceptualization of power offers little in the way of a possibility for resistance or structural change to take place that does not require the benevolence of those who wield power in a particular set of social relationships. It likewise leaves in place the potential for the conditions that produced vulnerability and reduced resilience to persist in the first place, thus failing to overcome political ecology's initial critique.

\section{Postanarchist resilience}

We see no special problem in the possibility of a coexistence of revolutionary, reformist, and reactionary elements at the heart of the same theoretical or practical doctrine. We refuse to play "take it or leave it," under the pretext that theory justifies practice, being born from it, or that one cannot challenge the process of "cure" except by starting from 
elements drawn from this very cure. As if every great doctrine were not a combined

formation, constructed from bits and pieces, various intermingled codes and flux, partial elements and derivatives, that constitute its very life or becoming.

- Deleuze and Guattari, Anti-Oedipus $(1977,117)$

Despite criticisms of resilience as being intimately bound to a broader neoliberal project meant to inoculate atomized individuals from the environmental and psychosocial traumas wrought by an unjust political economy, there is the potential for the term to be recaptured and used to represent the ability of people to survive and innovate in spite of oppressive systems. In line with the work of Deleuze and Guattari in their critique of Freudian psychoanalysis, there is no issue with resilience having a multitude of incoherent or even contradictory elements at its core (Deleuze and Guattari 1977). As a concept, the meaning of resilience and its role in both theory and practice are, in part, derived from its use. This creates the potential for resilience to become something radically different from what its intellectual progenitors ever intended (cf. Bogost 2015). Thus, rather than reject resilience as a concept tied specifically to the rise of neoliberal capitalism (see Walker and Cooper 2011), in this dissertation, I read resilience through the lens of postanarchism and political ecology to both develop a critique of the political economic systems which have dominated flood management strategies since the colonial era as well as a way of seeing the creative potential of colonized people in adapting to, reconfiguring, and resisting these practices (see Mullenite 2016). 
This postanarchist approach views the concept of resilience as always in the process of being defined in relation to the broader context of its use, where it is constantly being co-opted to meet the needs and ends of those who are wielding it, incorporating and superficially addressing critiques waged against it (cf. Chandler 2014). In the process, resilience and related concepts become a part of the discursive foundations of any given political economic system and can be used to understand and develop a critique of that system.

In recent years, geography and its related disciplines have seen a resurgence of anarchist and what could broadly be called postanarchist approaches (e.g., White and Kossoff 2007; Cudworth and Hobden 2010; Springer et al. 2012; Springer 2013a; Springer 2013b; Springer 2014; Wald 2014; Hammond 2015) As a discipline, geography's history is deeply entwined with anarchism thanks in part to the works of Élisée Reclus and Petr Kropotkin who are heralded as foundational thinkers in both circles, even if their anarchist contributions have been historically disregarded within geographic thought (MacLaughlin 1986; Springer 2012). Anarchist approaches to geography see the earth as an integrated whole that requires recognition of all of the relationships that make up that whole (Springer 2013a). These relationships are seen as naturally non-hierarchical but subject to domination and control at any point (MacLaughlin 1986; Springer 2012; 2014). The normative commitments of anarchism lie in the development of an understanding of how this domination occurs and in finding ways to overcome it, an idea that extends back to Kropotkin himself and has continued for more than a century since (1978; Springer 2014). 
Despite the extant historical connections between geographical and anarchist thought, recent poststructuralist approaches to anarchism are perhaps the most useful for understanding how power operates in complex socioecological systems. Postanarchism attempts the expand on the anarchist tradition by freeing it from its modernist trappings. While Kropotkin and Reclus offer significant insight into human-environment relationships, they understand these relationships as being an innate part of humanity corrupted by powerful outside forces. Postanarchism draws on postructuralist analyses to suggest that there is no outside corrupting power on its own but that competing discourses are combined to create topologies of power through which life continually molded (May 1994; Newman 2001; Collier 2009; Springer 2013b). However, resilience's implementation of the vocabulary of poststructuralism creates the risk of co-optation of critical responses based in poststructuralist analysis, including postanarchism (Chandler 2014). Among the earliest writings in this broad tradition is Hakim Bey's (2003) manifesto on the Temporary Autonomous Zone, which called for a radical reorganization of daily life around ideas individual autonomy that can only be occupied temporarily before being co-opted by the spectacle of late capitalism requiring a continuing reevaluation and reconfiguring of social and political life (see also Sellars 2010). Saul Newman (2011) extends this argument to suggest that anarchism has its own spatial imagination that seeks an ordered and planned society but where the planning is not imposed from above but rather develops from the social relationships that exist within that space. For Newman, this ordered but emergent space constitutes what might be called a postanarchist geographical imagination. It is a space where the organization of life and resources "emerges spontaneously, and which people determine freely for 
themselves" along horizontal means (Newman 2011, 347). While their nascent character makes the mechanisms that operate within these spaces indeterminable in themselves, postanarchism serves as a body of critiques meant to expose those discourses which privilege particular forms of authority (Springer 2013b). When resilience discourses coopt the language of poststructuralism, they do so in order to obscure the power relationships they produce (cf. Koch 1991). By tying poststructuralism to anarchism and thus challenging those linguistic deployments on the basis of their power to maintain the status quo, there exists the potential to destabilize the normative politics of resilience scholarship and expose its liberatory potential (Koch 1991; Springer 2013b). In this case, why certain discursive moves are made is as important as the content of the moves themselves (Foucault 2003). Because co-optation is used to obscure particular arrangements of power (Koch 1991; Springer 2013; see also Foucault 2003), an evolving and open-ended critique of these discursive movements can be used to undercut the foundation of this co-optation and continuously re-align the concept along a variety of potential forms, including liberatory ones (Mullenite 2016).

One clear example of liberatory resilience comes from the Spanish Civil War. In an interview with Pierre van Passen of the Toronto Daily Star in 1936, Buenaventura Durruti suggested a sort of resilience for working people around the world but a resilience the stems from their precarity in a capitalist system:

We have always lived in slums and holes in the wall. We will know how to accommodate ourselves for a while. For you must not forget that we can also build. It is we who built these palaces and cities, here in Spain and America and everywhere. We, the workers. 
We can build others to take their place. And better ones. We are not in the least afraid of ruins. We are going to inherit the earth; there is not the slightest doubt about that. The bourgeoisie might blast and ruin its own world before it leaves the stage of history. We carry a new world here, in our hearts. That world is growing in this minute. ${ }^{5}$

While Durruti was talking in very specific terms about the bombing of Spanish cities, we might see a similar process of ruination in the impacts of climate change that coastal communities, especially postcolonial ones, are feeling today. The workers of the world have the capability to build a new world based on their individual and collective ingenuity and a lifetime of experiences living in the margins of society, but are continuously disempowered in doing so either by their position in capitalist society, by the actions of the state, by social marginalization based on processes of identification (i.e. race, gender, sexuality), or most typically by an ad hoc combination of these. A key point of differentiation between postanarchist and other antiauthoritarian theoretical strains is understanding the movement and formulation of power and domination across a broad field of power relations that are always in flux and contested, never held in place by any individual or institution making it a useful tool for understanding these combinations (Newman 2001). Postanarchism provides a comprehensive system of theoretical movements stemming from the work of Michel Foucault, Gilles Deleuze, and Felix

${ }^{5}$ Additional text from the interview can be found at https://libcom.org/history/buenaventura-durruti-interview-pierre-van-paasen 
Guattari that allow for an in-depth understanding of the intra- and extra-personal relationships which structure and are structured by each other.

\section{Flood Control Infrastructure as Imperial Ruins}

I am not the first to use the imagery of ruination to understand capitalist legacies. In her introduction to a 2008 special issue of Cultural Anthropology, Ann Stoler suggests that imperial formations, including colonialism, leave ruins in their paths that must be understood in order to "reposition the present in the wider structures of vulnerability and refusal that imperial formations sustain" (Stoler 2008, 194). For Stoler, these ruins are not just inert remnants of history which sit idly in a landscape to be contemplated or remembered but rather contain a "material and social afterlife $[\ldots]$ in the gutted infrastructures of segregated cityscapes and in the microecologies of matter and mind" (Stoler 2008, 194). Rather than serving needs and interests of the present in a way that is cleanly ruptured from their colonial pasts, flood control infrastructure and the broader flood management regimes in which they are embedded act as a durable and active form of colonial governance that imparts the disjointed logics of colonialism into current political, economic, and environmental decision making (see also Stoler 2016). In other words, rather than colonial and postcolonial forms of flood management, there are instead disjointed and tenuous - but never the less present - direct connections between what might be considered a part of Guyana's colonial history and that which exists today, what Stoler (2016) calls colonial presence. Here, colonial inferences "wrap around contemporary problems; adhere in the logics of governance; are plaited through racialized distinctions; and hold tight to the less tangible emotional economies of 
humiliations, indignities, and resentments that may manifest in bold acts of refusal to abide by territorial restrictions imposed or in the flare of burning tires in "sensitive" urban quarter" (Stoler 2016, 4). In other words, the processes of decolonization which promised the freedom of the colonized more than fifty years ago were only ever meant to be partial, never complete.

Scholars of this neocolonial order, such as the Guyanese historian Walter Rodney, noted as much in their analysis of the processes of decolonization that began to occur en masse after the Second World War. For example, in his analysis of Tanzanian socialism, Rodney (1972) argued that the Arusha Declaration ${ }^{6}$ blindly accepted colonial ideas of governance and self-reliance at the expense of (and while co-opting the language of) indigenous alternatives. For Rodney, decolonization occurred as a constitutional practice that never questioned the legitimacy or the necessity of constitutional governance itself, leaving in place a key political factor introduced by colonizers and through which introduced features of colonial rule were guaranteed to be maintained. In this way, Rodney viewed any form of governance which was enacted through the constitutional state apparatus as part of a neocolonial endeavor which sought to make colonized people a respectable and legible part of the metropolitan world.

${ }^{6}$ Officially, "The Arusha Declaration and TANU's Policy on Socialism and SelfReliance." The document set out to outline the state socialist goals of the Tanganyika African National Union. The full text is available at https://www.marxists.org/subject/africa/nyerere/1967/arusha-declaration.htm 


\section{Genealogies of Race and Infrastructure in Guyana}

One of the primary ways this colonial engineering project has played out is through the explicitly racial politics of the broader colonial project. Race is only a single node through which colonial identities are constructed, interpreted, articulated, and perpetuated, but it is both significant and highly visible in the colonial and postcolonial world. As part of a complex set of ascribed identities, race has never been stable, clearly defined in biological terms or linked to a set of inherent characteristics. Instead, notions of race were produced within a logic of white supremacy in the colonial world which was itself intimately bound to and constructed with classed and gendered practices (Stoler 2008a). In turn, these determined what kinds of social intermingling were acceptable and those which were not while also determining who could reap the benefits of properly functioning flood management systems. Despite their unstable nature and their concatenation within a broader set of prescribed identities, the various and often ad hoc racializations that are used to define colonial subjects are among the most visible social dividers in colonial society.

By recognizing the contingent and constructed nature of race in Guyana, I seek to produce a genealogy of racial formation through the lens of water control infrastructure. Genealogies differ from other historical analysis by rejecting progressive or linear narratives in favors of those which examine the nominal, contingent, and contestable nature of historical enquiry itself (see Bevir 2008). While Mark Bevir (2008, 264), argues that the origins of genealogy lie in the method's ability to disrupt existing historical narratives - "exposing the contingent and 'shameful' origins of cherished ideas and entrenched practices" - I seek to use it as a way to understand the relationship between 
the materiality of nature and its domination on the one hand and the construction and naturalization of racial social and geographical practices on the other. While Antonio Ioris (2014) argues that the state serves its primary role as a political economic organizer (see above), I want to extend this to suggest that it is impossible to remove the political and economic dimensions of statecraft from the broader social dynamics occurring within the state. Thus, while state actions may have political economic impacts they are not reducible to these impacts but must be understood in a broader context of structural conservation wherein the main goal of state action and intervention is to maintain racial the status quo. In this way, rather than assuming that flood control measures were strictly functional, served only political economic purposes, or were largely racial in character (each commonly accepted in Guyanese and other coastal scholarship in various ways), I show how all these factors came together in various and emergent ways in order to respond to specific social conditions and, ultimately, the desires of the state.

In as far as it represents a coherent methodology for historical enquiry, genealogy is tricky. It differs from other historical methodologies through a focus not on what is, but how current aspects of everyday life have come to be (Bevir 2008). It requires not just an analysis of what is, but of what might have been and what could have been (Stoler 2016). It is analysis not just of the facts of history, but also of the politics and power relations which have made that history possible and legible. It is thus a history not just of what is said to be, but also of the various imperial refusals hidden within the disorganization of the colonial archives (Stoler 2008). It calls into question the ontological and epistemological grounds upon which things (material, conceptual, and those which exist firmly at the confluence of the two) exist and how this existence might preclude other 
possibilities for being in a given time and at a given place. Thus, it requires some degree of speculation and interpretation about the social and political imaginaries left out of the colonial record (Stoler 2016). It provides a history of the present (but not necessarily a presentist history) and examines the multiple temporalities (e.g. colonial and "post-" colonial) in which people live.

This dissertation takes as its aim a genealogy tied to British Empire, but it does so in a particularly colonial space in which imperial materiality is mediated by processes of flood management and the intense racializations and racisms applied to colonized populations. I draw implicitly on the work of Michelle Kooy and Karen Bakker (2008) who argue that infrastructure acts as a "technology of government" through which spaces and subjectivities are constituted, ordered, and integrated into broader governmental agendas where they can be marked or otherwise made legible and thus subject to control (see also Scott 1999). I likewise draw inspiration from the work of Sarah Pritchard (2011) who argues that environmental management projects produced a wide variety of political affects which shaped the everyday lives of citizens under these environmental regimes. As I have argued elsewhere, infrastructure can have important political effects resulting from the way it is designed, built, and managed that pre-exist its stated or implied technical goals. It acts as a mediator and enforcer of state interests, defining the ways the state can enter everyday life and, in turn, it shapes the possibilities of life around the goals of the state (Mullenite forthcoming; see also Meehan 2014). Environmental management in the form of flood control and the infrastructure necessary to support it serve as an important site for authoritarian governance that is often overlooked, echoing recent arguments from Jessica Barnes $(2017,149)$ that "the bureaucracy and technologies 
of water management can be seen as one of the conduits through which [state] authority may be both forged and contested." These everyday practices render the authoritarian governance practices of both the colonial and postcolonial periods a banal part of daily life, allowing for new authoritarianisms to creep in largely unnoticed.

However, I do not want to suggest that colonialism was in itself only an authoritarian practice to which there was no possibility for resistance. I focus on the discontinuities of colonialism in Guyana, the efforts to build alternatives to colonial experiences by Guyana's working populations, and the ways in which the colonial state apparatus refused to legitimize these alternatives. As Ann Stoler $(2016,72)$ has argued, "already knowing a colony precludes asking whether ambiguous nomenclatures, competing visions, repeated failures, and reversals of course (and the violence and fortressed settledness they engender) prefigure "the colony" as something else-rather than a site of settlement, an always unstable and precarious project, plagued by the expectant promise (and fear) of its becoming something other than which its visionaries prescribed." This view of the colony itself as unstable begs the question of the differentiation between the colonizers and the colonized. How are these categories performed in colonial spaces? How does the built environment act as a boundary in which this dichotomy is produced, enforced, and reproduced? Rather than simply providing protection for coastal populations and economies, the main argument of this dissertation is that flood control infrastructure itself played a key role in the fields of power which not only structure contemporary coastal life, but which also are a product of a long history in which colonial Guyana was defined along infrastructural lines, differentiated from the metropolitan other by a relationship of security from flood waters. 
To put it explicitly, I understand the ways in which problems of flooding and flood control were used to "solve" a number of crises of legitimacy, first the political-economic legitimacy of colonial regimes and later the governmental legitimacy of postcolonial governments. In other words - and speaking more directly to the work of Michel Foucault who popularized genealogy as a method for historical enquiry - flood control projects act in a broader imperial genealogy of racism in which "disciplinary projects that target the body and biopolitical technologies that target the population" converge and become part of a larger project of governmentality (Rasmussen 2011, 37). It is through a genealogical method that I show that flood control was one of the means by which colonized bodies were raced and thus differentiated and able to be targeted explicitly by the colonial state.

In this way, this dissertation also offers genealogies of environmental racism in Guyana. Plural because the environmental racisms felt by different racialized ethnic groups in the country do not necessarily share origins, even if, broadly speaking, the operations of power at work in their histories can be located in the same political and economic conditions. Environmental racism emerged as a framework for understanding the disparate, and disproportionately negative experiences, of working class communities of color to environmental hazards, particularly as they related to exposure to pollutants (Pulido 1996). This analysis has strong resonances with approaches that seek to understand what Bobby Wilson (2002) has called "race-connected practices." For Wilson $(2002,31)$, "race-connected practices" refer to "practices resulting from racism-negative attitudes groups of people or individuals belonging to one race hold about individuals or groups of people belonging to a different race." To understand these race-connected 
practices, their origins, and their affects, one must also understand the historical and geographical contexts from which they are born and within which they operate (Wilson 2002). In the context of Guyana, this means better understanding the sometimes intimate and sometimes disparate connections between racism (colonial and contemporary) and the variety of practices and environments in which they developed. Thus, while outlining a particular environmental history of racism, it is one that is contingent on the details contained within and does not simultaneously exclude other possible origin stories. Importantly, this means that the inclusion of Guyana's other ethno-racial groupings beyond the Amerindian, African, and Indian communities is largely missing from this dissertation. In focusing on flood control infrastructure in particular, I am choosing to privilege the stories of those colonized people who would themselves come to settle and take power in formerly colonial lands. The stories of Chinese and Portuguese indentured laborers have been told elsewhere, for example in the excellent works of Walton Look Lai (2004) and Sister Mary Noel Menezes (2010), respectively.

\section{Methods}

This project draws on mixed, interdisciplinary methods to answer the various research questions posed both here in the introduction and in each of the following chapters. These include historical methods, rooted in archival research conducted in London in the summers of 2015 and 2017, and ethnographic research conducted in Georgetown and its surrounding suburban and exurban areas in the fall of 2017, and textual analyses of a variety of governmental and non-governmental publications. I 
supplement the archival research with newspaper accounts available through common library databases such as the Center for Research Libraries.

First, using the online database provided by the National Archives in London, UK I searched for all documents potentially related to flooding, sea defenses, drainage and irrigation, the rice industry, and the sugar industry as well as key locations located along the coastal plain (see Appendix A). These items were categorized using an excel spreadsheet where they were assigned different priorities based on their potential relevance to the research project assumed from brief descriptions provided on the website. I ordered a sampling of these documents digitally in 2014 to confirm the validity of the priority assignment. In the summer of 2015, I spent three days in the archives digitizing high priority files. I skimmed these documents and, based on key names and dates, I preformed additional searches and additional potential research items were added to the file index. In the summer of 2017 , I returned to London where I continued digitization. Once all files were digitized, they were converted to PDF files and imported into Atlas.ti qualitative data analysis software. Here, I read and coded based on keywords relevant to the dissertation using a process of open coding (e.g. "sugar," "rice," "flooding," "race," "labor," etc.) I linked the codes to specific quotes in the documents which could be examined both in relationship to each other and in the historical context in which they were stated. These methods are used primarily in chapters 2 and 3. Similar method of coding was used for newspaper accounts and supplementary documents cited in chapters 2,3 , and 4 .

By disassociating the various archival documents from their colonial orderings and placing them in the broader context of the colonial project I was able to reassemble 
the stories that had been unceremoniously scattered into hundreds of small boxes in London. In the production and location of specific documents within the archive, colonial administrators produced contexts from which they wanted their thoughts and ideas to be understood (cf. Stoler 2015). The arrangement of pages, the notes and corrections made long after the fact, and the inclusion and exclusion of related materials were a way ordering knowledge and producing specific Truths about the colonial project ex post facto. While this ordering can in itself provide important insights into the larger colonial project, it is most successful in its obscurantist goals. Beyond official memoranda, the archives contained the conversations between administrators and minutes from their meetings that, detached and spread across dozens of individual boxes show cool discussions but which show larger colonial anxieties when reassembled. The large quantities of archival materials gathered, even if not quoted or cited in this dissertation, helped to form the broader social topographies in which colonial ideas, practices, and the decisions made by individuals within and outside the Colonial Office are understood in this dissertation (Stoler 2015, 153).

I spent the fall of 2017 living in Georgetown where I conducted 52 interviews with coastal residents (see Appendix B). Interview participants represent a range of ethnic groups, age groups, economic classes, and educational backgrounds but lived within 10 miles of Georgetown. Sampling was done via "snowballing," whereby participants would introduce to me to other potential participants. Though typically used to identify and recruit research participants among marginalized populations, snowball sampling has also been shown to be a useful method for generating emergent, political, and relational social knowledge (Noy 2008). While all consented to be part of this 
research, only 10 agreed to be recorded. For the 10 recorded interviews, I transcribed them using F4 transcription software before importing the transcriptions into Atlas.ti and coding them utilizing the same methods as above. The remaining interviews were noted in my field journal and have been used to reflect on my own experiences and conversations in the area but are not quoted directly and are not used as a means for discussing the ways in which people understand questions of government action but do provide some background on how floods might be experienced. Because my goal with this research is not to produce generalized statements about Guyanese experiences with flooding but instead to explore the depth of individual experiences, there was no need to reach theoretical saturation and thus the relatively small number of recorded interviews does not affect the significance of their content. Instead, participant experiences are used to outline varied experiences of flooding in the country's urban coastal landscape. I draw on these interviews and my own experiences to inform research in chapter 4.

\section{Organization of the Dissertation}

The storytelling in this dissertation is non-linear. I do not move neatly from yearto-year for the sake of historical consistency, but instead focus on the interactions between laboring populations, the economy, the environment, and the state. This does not mean that what is discussed in one chapter is not affecting the conditions being addressed in the others. The creation of the Political Action Committee and eventually the People's Progressive Party (discussed in Chapter 4) certainly had an impact on discussions of unemployment in the sugar industry (Chapter 2) and in the creation of the rice industry (Chapter 3), but, based on the sources drawn upon, those connections have only been 
made when they could be affirmatively connected to the broader projects being discussed.

One of the key arguments made at the end of the dissertation is the need for decolonization of coastal processes. During my time in Guyana I spoke with several stakeholders in this process to better understand what it might mean to make that a reality. I have personally little to offer Guyanese other than a critical analysis of the situation at hand and so understanding what of this analysis would be useful for Guyanese people forms a key part of what may be called the praxis of the dissertation. While not an activist-research project, the dissertation is written and organized in such a way that it is not a purely extractive exercise through which the historical suffering of people is used to further my own career. In line with Todd May's arguments for a postanarchist ethics, this project seeks, as far as possible, to avoid "representing others to themselves - in either who they are or what they want -" while allowing other ways of knowing and doing to flourish (May 1994: 130). This has ethic has been extended historically as well. In this way, the dissertation itself serves in some ways as an attempt, however minor, at working toward the process of decolonizing geographical scholarship in general (see Radcliffe 2017; de Leeuw and Hunt 2018) and posthumanist geographies specifically (see Sundburg 2014).

Based on these reflections, I begin this dissertation with an overview of the precolonial and early colonial social and environmental history of the area that is now within Guyanese borders. In chapter 1, I examine the role of Dutch-Amerindian Trade in the modification of present-day Guyana's coastal plain between 1590 and 1790. I argue that processes of indigenous erasure related to a colonial and postcolonial politics of 
belonging on the coast have shaped the narrative of coastal settlement in Guyana.

Drawing on a variety of colonial-era sources and more recent ethnohistorical accounts, I argue that, rather than a coastal plain void of human life, ready to be canalized and dammed for colonial exploitation, coastal Amerindian groups played a significant role in setting the conditions for colonial settlement on the coast only to later be displaced and erased from the country's history by British historians. I show that geopolitical arrangements among South American and Caribbean colonies were shaped by DutchAmerindian trade agreements. As the Dutch lost power in the region through colonial warfare, these agreements became less valuable to Amerindian groups allowing for their displacement to areas further inland. This is key because understanding both the social and natural processes that existed prior to colonization are important steps in understanding decolonization. While there can be no return to that past, it does offer insights for potential futures.

In Chapter 2, I trace the development of coastal flood infrastructure through the sugar industry beginning with emancipation in 1834 and ending with independence in 1966. Drawing on archival research conducted at the National Archives in London, UK, the Walter Rodney Archives in Georgetown, GY, and accounts from local newspapers such as the Daily Chronicle, I examine two case studies: coastal flooding in African Villages in 1886 and 1887 and infrastructure development during sugar relief works in the late 1920s and early 1930s. I argue that, rather than a backdrop upon which colonial processes occurred or simply another way of seeing and understanding the exploitation of colonized people, flood management acted as a form of colonial governance in itself, 
serving as one of the principle means of colonial political and economic exploitation in the post-emancipation period.

Beginning in the late $19^{\text {th }}$ century and extending through the post-World War II period, British colonizers began expanding their presence in coastal lands through the development of a rice industry while also managing the relationship between South Asian- and African-descended people in the colony. In chapter 3, I analyze the development of this system of rice production, tracing its origins both to economic instability in the sugar industry and to the need to provide land for indentured laborers whom the British could not afford to send home after their indentureship had ended. I argue that, in addition to these functional purposes, new forms of land tenure provided under these colonization schemes required new legislation regarding flood control infrastructure construction and maintenance. These differences, coupled with distinct positions within the colonial political economy, were used to drive ethnic divisions between Afro- and Indo-Guyanese people as means to preserve colonial power in the face of growing anti-colonial sentiment.

Finally, in chapter 4, I examine the ways in which postcolonial governments have managed flood control systems since 1966, focusing in particular on the racial conflicts between Guyanese people and how these have been mediated by and through their experiences with flooding. Based on semi-structured interviews conducted along Guyana's coast in the fall of 2017, I analyze the relationship between race, flooding, and political and economic development in the postcolonial era. I place current drainage, irrigation, and flood control problems in the context of a shifting postcolonial political economy, moving from the mixed economy offered by the first coalition government, 
through to the rise of Forbes Burnham's Jucheist-inspired socialism in the 1970s, and the period of privatization experienced from the 1980s to the present. Drawing on government documents, interviews with coastal residents, and my own experiences living in Guyana's capital city of Georgetown, I also examine the changing epistemologies of river and sea defense during an era of sea level rise and the role of mangrove restoration in undoing some of the threats created by the country's colonial past.

I conclude by thinking about the role of colonial ruins in shaping contemporary sociospatial patterns of coastal life broadly and consider some potential lessons offered by Guyana's history. I contend that processes of imperial ruination and the role of infrastructure in acting as a form of governance offer innovative ways of thinking about socioecological concepts such as resilience. If resilience refers to the ways in which socioecological systems adapt and change based on their conditions as a means of survival, then in what ways might colonial aspects of these systems, whether embedded in the material culture of a region or in the various institutions held over from the colonial period, persist and thus be resilient? How does this resilience impact people's experiences of vulnerability today, tomorrow, and in the decades to come? I show both how resilience is a useful analytic for understanding the ability of people and institutions to survive while also exploring its current epistemological limits and its role in perpetuating colorblind environmental racism. Finally, I draw out a few ways that we might be able to dismantle colonialisms' infrastructural legacies and avoid engineering a new colonialism. 


\section{CHAPTER 1 - THE PRECOLONIAL AND EARLY COLONIAL HISTORY OF COASTAL SETTLEMENT}

Guyana's coastal plain stretches approximately 250 miles from its eastern border at the Corentyne River to its terminus just west of the border of Venezuela. Rarely extending more than 6 miles inland, this narrow and shallow coastal system is part of a larger 750-mile long system of low-salinity mudbanks called the Amapá-Guianas coast, which extends northwest from the delta of the Amazon River in the Amapá State of Brazil to the Orinoco River in the Delta Amacuro State of Venezuela, making it the longest mud coast in the world (Allison et al. 2000). Like other mud coasts, the mudbanks lining South America's northern edges drift in regular intervals as a result of broader climatic variations. In this case, they move to the northwest through a process that varies in both speed and intensity with the trade winds that helped make the Caribbean attractive for early colonial settlement (Allison et al. 2000; Vaughn 2017).

While the elevation of the coast itself varies across Guyana's stretch, it is relatively low-lying, with large sections below mean sea level and otherwise featuring very little geographical prominence (see Figure 1). Punctuated by four rivers originating in the Guiana Shield along the Guyana-Brazil border (from east to west, the Corentyne, Berbice, Demerara, and Essequibo), regular flooding of freshwater from the hinterlands also shapes coastal processes. River floods deposit silts and other debris which in turn produce natural embankments along the coast. These same swells also silt the outfalls of the various canals which drain the coastal landscape, contributing to broader coastal flooding when flood gates cannot be opened. The large watersheds of these major rivers 
flood regularly flood pockets of land inland from the coast and provide a valuable source for fresh water for human settlement. This combination of coastal and riverine systems produces what would be highly dynamic coastal geomorphology, exhibiting regular and rapid patterns of accretion and erosion, if not for the efforts of 18th century colonials seeking the geomorphological stability necessary for the establishment of an agrarian political economy.

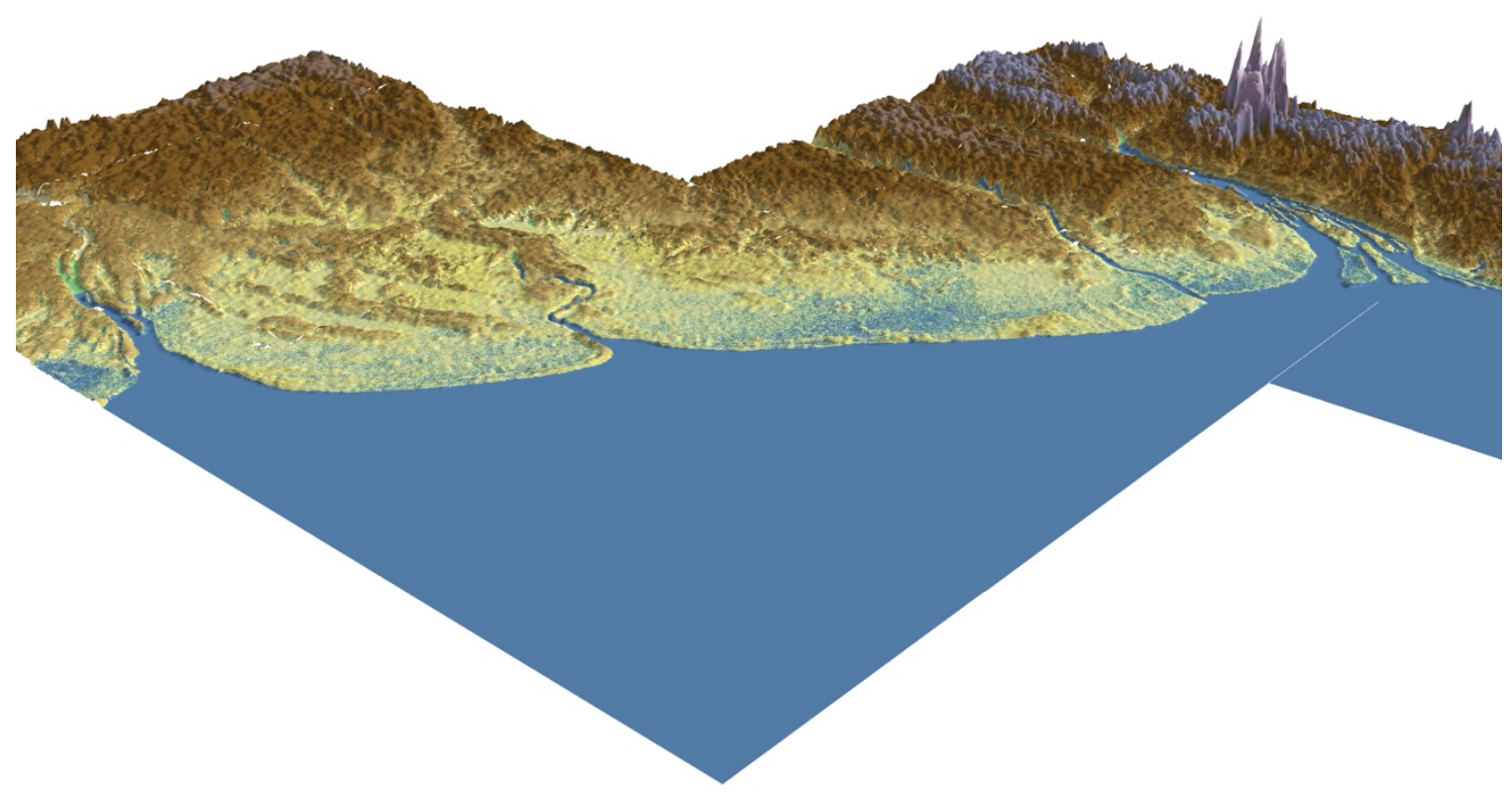

Figure 1-3D model showing the coastal plain from the Corentyne River (left) to the Essequibo River (right). The Berbice and Demerara rivers are also shown. Data based on ASTER DEM. Elevation exaggerated 50x. The peaks on the right are the result of data anomalies. Rendered by author.

Today, people inhabit only about two-thirds of Guyana's section of the coast. The towns of Corriverton in the east and Anna Regina in the west mark the extent of concentrated coastal settlement resulting from the two centuries of intensive agricultural 
development first introduced by British, French, Dutch, and German colonial settlers in the $18^{\text {th }}$ and $19^{\text {th }}$ centuries. The patchwork of rice and sugar fields, pocked by numerous towns and villages named after the plantations that once stood in their locations, are drained by more than 4000 miles of canals and protected from the sea by a combination of concrete sea walls, rip rap, and dense mangrove forests (Thomas 1984; Vaughn 2017). Like the villages bearing the names of plantations long gone, this water infrastructure is part of Guyana's imperial ruins, serving as an active part of the country's political and economic landscape while also maintaining the geophysical alterations which allowed that landscape to come into being (cf. Stoler 2008; 2016). They thus serve as a valuable representation of the dialectical relationship between human desires (for economic prosperity, security, and freedom) and geophysical forces which are a part of coastal landscapes around the world. In this chapter, I draw on insights from critical physical geography to understand how early colonial politics and settlement patterns marked the path for later agrarian development and set the stage for the frequent flooding along the coast. I draw on the explorer narratives and "natural histories" written during the early colonial period along with more recent ethnohistorical analysis to understand what attracted people to the region as well as how broader colonial patterns of life shaped the geophysical environment of the coast. Natural histories produced during the colonial period are, in themselves, extremely problematic for their selective representations of events but serve as fruitful insights into the colonial/settler perspective on history.

Though relatively new as a subfield of geography, critical physical geography has its roots in earlier attempts at understanding the ways in which social factors (including political formations, economic systems, and social norms and mores) impact and are 
impacted by geophysical factors (see Tadaki et al. 2012). Critical physical geography differs from these earlier attempts at bridging the gap between the field's two largest realms by focusing explicitly on the role of power relations in geophysical processes (Lave et al. 2014). As Rebecca Lave and colleagues put it, "socio-biophysical landscapes are as much the product of unequal power relations, histories of colonialism, and racial and gender disparities as they are of hydrology, ecology, and climate change" (Lave et al. 2014: 3). Employing this framework, I show how the socio-geophysical characteristics of the land (i.e. a landscape heavily modified for economic purposes through extensive drainage and irrigation infrastructure) are produced alongside a politics of belonging on the coast. Thus, rather than simply providing early historical context for the following chapters, this chapter specifically examines the socio-biophysical production of Guyana's coast up to the beginning of the British colonial period in the late $18^{\text {th }}$ century.

While later chapters investigate the wide-ranging political, economic, and social causes and consequences of flooding along the coast, this chapter analyzes its origins in the political and economic processes brought by Dutch colonialism. I begin by providing some background on the geomorphology of the coast. I draw on literature from geology and physical geography to understand the geophysical processes by which Guyana's coastal plain developed as a site suitable for colonization. Next, I draw on ethnohistorical and archaeological research to consider indigenous land use practices along the coast prior to colonization. I challenge existing arguments that the coast was uninhabited prior to colonial settlement and contend instead that these arguments exist in the colonial and postcolonial literature as part of a larger politics of indigenous erasure. Finally, through an examination of the early colonial history of Guyana, I seek to understand the political 
and economic processes that made the discursive erasure of Guyana's coastal indigenous populations possible, linking it to land settlement practices that were patterned in the process of colonial warfare.

This early history provides important foregrounding for understanding the operations of colonial political economies and anti-/postcolonial desires for a "Guyanese" state in as far as colonial and postcolonial governance has focused primarily on the coast and not the vast and sparsely populated hinterlands. It helps provide insights for both the reasons and the means by which colonialism and the requisite flood control infrastructure that supports it developed and thus helps shape a further, more historical understanding of problems relating to socioecological resilience on the coast. In turn, it also provides some insight into state formation in the region, providing further understanding the processes that shape coastal vulnerability today.

\section{The Geophysical History of the Guiana Coast}

The 750 mile Amapá -Guiana coast is one of the muddiest in the world (Anthony et al. 2010). When the earliest potential colonizers arrived in the area they found dense mangrove forests, impenetrable pegasse swamps, shifting sand bars and difficult to navigate currents. By the early $17^{\text {th }}$ century, English colonials had already taken to referring to this challenging and inhospitable land, sandwiched between Spanish and Portuguese claims, as the "Wild Coast." (Edmundson 1901; Mathews 1966).

The land itself contains a few different geomorphologies, each contributing different features that would eventually make the area an attractive place to settle. Prior to colonial settlement, sea water covered much of the shallow coastal plain at high tide, 
giving way to coastal saltmarshes and dense mangrove forests sitting on top of shallow beach ridges and chenier (semi-circular shell and sediment) formations (Brinkman and Pons 1968; Daniel 1989). The cheniers are formed, in part, by mud flowing northwest from the Amazon delta by an equatorial current (Richardson 1987). Bonham Richardson (1987) has suggested that chenier formation is Guyana, and mud accretion more generally, may be due to the shape of the coast. However, these cheniers make up only a small portion of Guyana's coastal plain and are relatively young, dating back to a little more than 2500 years ago, at their oldest (Daniel 1989). Despite this, they have served an important role in creating natural breaks, protecting the land behind it from wave erosion, giving way to the brackish and freshwater tidal clay flats and marshes that support mangrove ecosystems (Brinkman and Pons 1968; Daniel 1989).

Black (Avicennia nitida, historically referred to as courida) and red (Rhizophora mangle, pictured in Plate 3) mangroves covered these flats when brackish and, once desalinized, develop a thin layer of pegasse which, when reintroduced to salt water form deeper peat swamps (Brinkman and Pons 1968). The mangroves have historically acted as a natural protective barrier from wave action on the coast, slowing erosion. As waves approach, they break on mangrove hammocks rather than the sea shore itself. The dampening effect of the mangroves can also help accretion processes by trapping the muddy soils suspended in the coastal sea water. Conversely, and much less commonly, wave action can break down sections of mangroves turning them into a corrosive element that hastens shoreline erosion (Rodway 1912). 


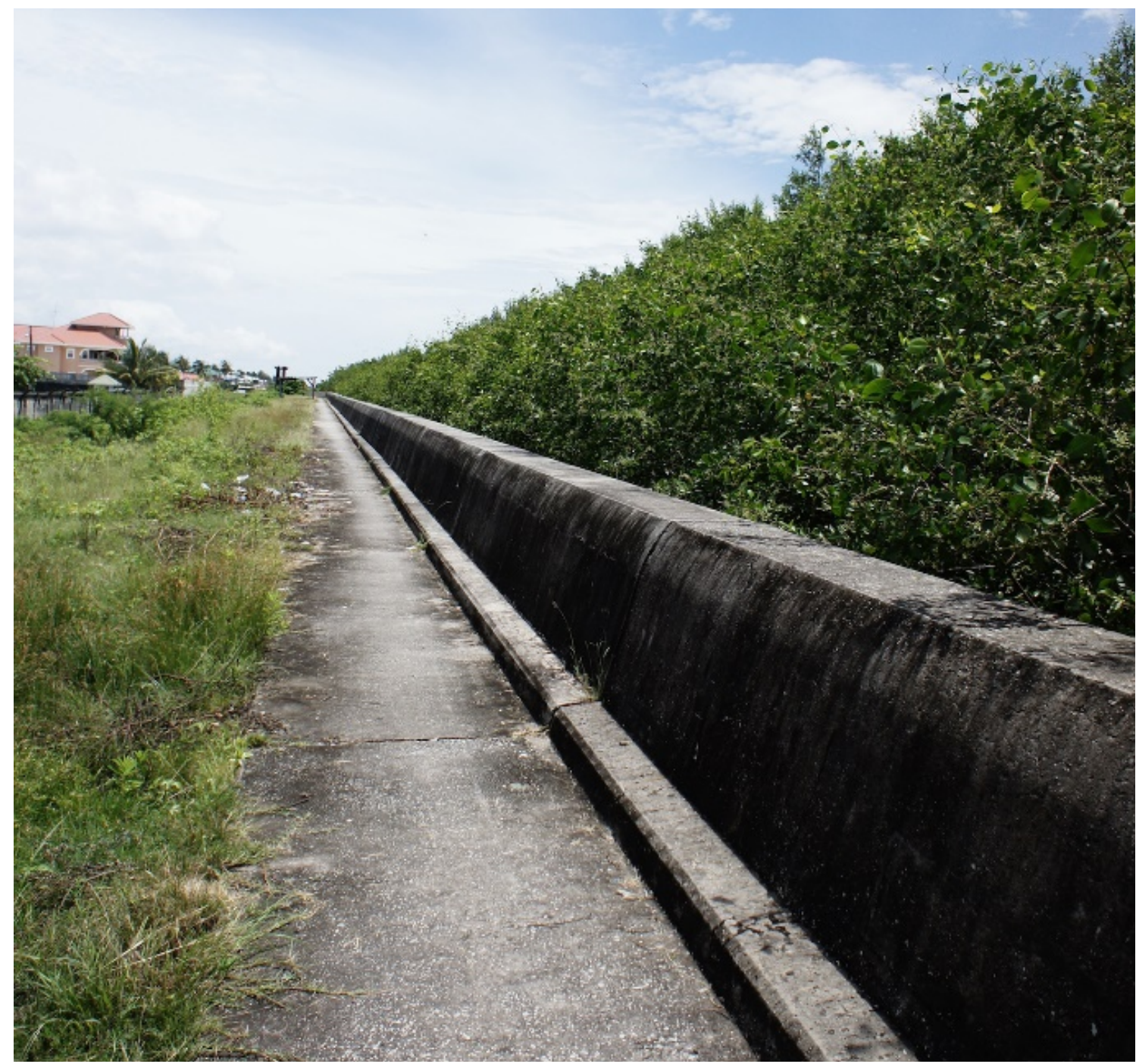

Plate 3 - Red Mangroves and Seawall in Beterverwagting, East Coast Demerara, June 2016. Part of the Guyana Mangrove Restoration Project. Photo by author.

Like the mud that travels up the coast from the Amazon, the inland soils along the coast tend to be clayey, with some silt carried down by the various rivers. As these silts deposit along the banks of the rivers, they form natural levees which kept clayey soil of the swamps from washing out to sea except at the highest flood of the river. As accretion occurs and formerly waterfront lands "move" further inland, the salt desiring plants die 
off, turning the soil into pegasse - a mixture of clay, silt, and decaying vegetation.

Pegasse soils are waterlogged in the wet season and arid in the dry season, making them difficult to manage. In the most densely populated areas of the coastal plain, the pegasse regions are used as part of the water conservancy system before giving way to "palm march forest" made up primarily of chewstick (Symphnoia globulifera), pracaxi (Pentaclethra macroloba), and partridge wood (Vatairea guianensis) trees.

Sandy formations, locally known as "reefs," exist (particularly around Berbice) but they are the exception to a coast that is primarily clay mixed with other dense and nutrient rich soil types (Brinkman and Pons 1968). These reefs are typically utilized for the production of tropical fruits, such as pineapple, mango, guinep, and coconut, that either do not grow well in the frontland clays that make up much of the rest of the coast or have been relegated to these secondary soil types as frontland soils are typically used for the more economically productive sugar and rice along with, in the villages, subsistence crops such as cassava and yams (see Chapter 2 - "A Mild Despotism of Sugar”: Race, Labor, and Water Management).

Like similar coasts around the world, Guyana's coast consists of stepped planation surfaces, with each major step tied to specific erosive events (e.g. nonanthropogenic sea level rise; McConnell 1968). It is unclear how permanent settlement on the coast and how sea and river defense structures, drainage and irrigation infrastructure, and soil modification for agriculture might affect large-scale coastal erosion and accretion in the future in Guyana. However, the colonial record is filled with plans for engineering works that aimed to help to slow down accretion due to silting and there are several examples of plantations abandoned to the sea after erosion caused their 
sea walls to collapse and their lands to flood. As a more general move to prevent flooding, but which may help with accretion, there has been a movement to restore the mangrove forests that line the coast which has experienced mixed results (see Vaughn 2017; Chapter 4 - Colonial Persistence: Race, Class, and Flood Control Since 1966). What is clear that these types of events have created a clearly defined coastal plane with rich, dark soils, geologically distinct from the larger grassland savannahs and forest lands (and the sandier soils associated with them) behind it and that this geographical diversity created the conditions for both the current population geography of the country and the ways the people living there experience flooding.

\section{Indigenous Land Settlement and Use}

While much of the geophysical history of the coast can be inferred through geological and soil surveys, the historical use of the coast by indigenous peoples in Guyana prior to colonization is, thus far, poorly understood. Recent archaeological surveys have largely excluded coastal areas, focusing instead on the savannah and forest regions as well as a few midden sites near, but not entirely on, the coast (see, e.g. the work of Denis Williams, Betty Meggars, Clifford Evans, and articles in the journal Archaeology and Anthropology). This may be in part due to the dense development of many coastal regions, either as cities, towns, and villages, or as spaces for agricultural production. Thus, some of the best accounts of pre- and early-colonial coastal life, including with regards to indigenous use comes from colonial-era accounts themselves. From the early $19^{\text {th }}$ to the early $20^{\text {th }}$ centuries, scientists, missionaries, and colonial officers wrote a number of "Physical and Natural Histories" and memoirs of life in 
British Guiana, often including significant analysis of the time before their arrival. While the violence of colonialism tinges these writings and while they are also littered with inaccuracies, through comparative analysis, they can also act as an important repository of information from which new analyses can proceed. They likewise provide valuable insights into the settler perspective on history, highlighting what was important to record and, in various absences, what could be discarded.

For example, in his history of Guyana, James Rodway (1912) notes that human remains and artifacts were found during the initial digging on plantations in the East Coast Demerara region, but that they were not preserved nor properly investigated, making it difficult to know if these were graves tied to a settlement, ritualistic burials, or people from other areas buried during trips to the coast. Regardless, it does indicate that there was some indigenous use of coastal lands and that this may have been significant. Adjacent to the coast between the Orinoco and Essequibo rivers, early colonial settlers found large midden (refuse) piles that indicate a fairly dense population at some point in history. The content of the midden piles also points to the existence of a pre-colonial, indigenous coastal lifestyle, with subsistence based primarily on fish and mollusks (Rodway 1912). In 1665, shortly after attacking the colony of Essequibo, English Major John Scott estimated that there were more than 42,000 Carib (today Kalina/Karinya) families living in the broader Guiana coastal region, with Arawak (Lokono) and Warow (Warao) tribes living further inland along the rivers and savannahs (cited in Rodway 
1912). Rodway does not include a source for Scott's figure ${ }^{7}$ and is skeptical of the number as he counts each "Indian family" as being about a dozen people, placing precolonial population estimates in the same range as the population at the height of colonialism and about 60 percent of the current estimated population. He suggests instead that the word family should be substituted with people, making the population significantly smaller. However, it is not clear to what extent Scott was referring to in his discussion of the coast and Rodway does not attempt to clarify. Thus, Scott could have easily been referring to the entire coastal plain (from the Amazon to the Orinoco) or only to the coast and adjacent areas that make up present-day Guyana. Likewise, precolonial populations significantly larger than colonial estimates have been found throughout the Americas, indicating that Scott's assessment may have been accurate even if restricted only to the modern Guyanese coast (cf. Mann 2005). Regardless of the actual numbers, Rodway, via Scott, provides evidence that, at least up the mid-1 $17^{\text {th }}$ century, the coast had a relatively large number of indigenous inhabitants linguistically distinct from groups living in the savannahs and forests of the interior.

In other ethnohistorical studies of Guyana's Amerindian population, the simple argument put forward by Rodway is challenged somewhat by a more complex system where Carib groups shared portions of the coast with Arawak and Warao. According to Edwards and Gibson (1979), at the time of their writing Arawaks constituted the bulk of

${ }^{7}$ It likely comes from memoirs, letters, or notes related to Scott's 1665 attack on Fort Kyk-over-Al. Scott successfully took over the fort for a brief period of time before being ousted by Dutch soldiers from Berbice. 
Guyana's Amerindian population and lived primarily on the coast, replacing the Warao who may be descendants of the earliest settlers in the Guyana region, especially around the Orinoco River. To support this claim, they argue that Warao have particular cultural adaptations that suggest they have lived in the coastal area for a long time, such as expert boat building. This same evidence was used, however, by Rodway (1912) to suggest that Warao people historically lived up stream along the rivers where they would have access to both tropical hardwoods and water, while Caribs and Arawaks dominated the coastal zone, a point supported in the ethnohistorical record (see Whitehead 1990).

Despite this evidence of coastal indigenous land use, there is relatively little Amerindian presence in Guyana's coast today. With the exception of the Umana Yana (a cultural center built in the 1970s in the center of Georgetown), the Walter Roth Museum of Anthropology, and small villages inland from the coastal towns of Anna Regina and Charity, there is little reference to indigenous life at all in the cities, towns, and villages that line the modern coast. Historians such as Walter Rodney have to some degree explained this away. Rodney (1981) suggests that, by the time of colonization, indigenous life had mostly moved inland where they had a somewhat neutral relationship with colonizers who were not interested in the country's hinterland after initial searches for the famed El Dorado were unsuccessful. Drawing on accounts produced by Rodway and other early historians of the region, Rodney argues that the indigenous population of the country in the early colonial period acted as accomplices to the colonizers, catching Africans seeking to escape their bondage in the country's dense forest lands. Early archaeological investigations which focused primarily on the hinterland support this argument to some degree and ethnohistorical accounts do show that Carib groups were 
used for slave patrol work (see e.g. Evans and Meggars 1960; Whitehead 1990). Shona Jackson (2012) argues, however, that this is part of a long-standing politics of belonging which centers on the experiences of Afro- and Indo-Caribbean peoples at the expense of indigenous experiences.

For Jackson, Afro- and Indo-Guyanese peoples sought to construct a creole identity in which they tied their belonging in the country to a coastal existence, with some portions of Guyanese society going as far as to claim that the country's Amerindian populations are not Guyanese at all (see also Sanders 1972, 1976). By considering indigenous populations as only a product of and thus belonging to the country's underdeveloped hinterlands, they were able to produce a type of "creole indigeneity" which granted them rights to Guyanese territory and acted as fuel for the anti-colonial movements which sprang up in the post-emancipation and post-indenture periods (Jackson 2012). In this way, colonized people brought to Guyana were staking out their claim on what they considered to be a no-man's land prior to colonization and which would ostensibly be a no-man's land once colonialism ended. The nutrient rich clays of the coast were available to the colonizers and thus were available to develop a new, postcolonial political economy in which the riches of the English could become the riches for all. These accounts were verified during my fieldwork on the coast and in conversations I had with numerous coastal residents and teachers who told me that the idea that the coast was terra nullius prior to colonization is part of the state-sanctioned curriculum for primary school history.

While Jackson covers this politics of belonging in great detail during the colonial and postcolonial periods, she does not address (at least not in a satisfactory manner) how 
this came to be. Through her focus on myth, Jackson usefully highlights various narrative forms of Amerindian cultural erasure, but the actual displacement of Amerindian people is assumed from the beginning to be similar to that of the rest of the America's, where histories of slavery and ecological imperialism ravished native communities. While she challenges the idea that the coast has never been Amerindian, she implicitly accepts the argument that, even during the early colonial period, Amerindian life had been relegated primarily to the hinterland. Rather than beg the question, as Jackson does, it is worth asking: If there is first hand and archaeological evidence of widespread coastal settlement, and there is evidence of collaboration between Amerindian groups and early colonizers, what happened in the years between that coastal life and the development of the coastal agrarian system? How did Amerindian coastal life influence the later political economies and social experiences of the coast? How did these politics work to shape the geophysical processes at play in the Guyana's coastal zone?

\section{Amerindian Trade and the Beginnings of Guyanese Colonialism}

There is little relatively little written on the early Guyanese colonial period, owing in part to an often confusing and scattered archival record, a relative lack of Dutchspeaking historians interested in the topic, and a general lack of interest in the Dutch Guianas prior to the 1763 Berbice Slave Revolt (Oostindie 2012). There are likewise only limited accounts of Dutch colonial history in the West Indies prior to 1688 when the colonies became a more important part of the Dutch colonial project and thus became something worth writing about in the colonial eye (Oostindie 2012; van den Bel, Hulsman, and Wagenaar 2014). I draw largely on the work of James Rodway who, for all 
his faults, was a serious historian of the region who drew together a number of disparate accounts in an attempt to make sense of the colony's history, providing a uniquely British colonial perspective to other, Dutch-oriented sources. According to Rodway (1893; 1912), despite earlier "discoveries" by the British and Spanish, the first European traders to successfully settle in the Guyanese coast were the Dutch who, prior to their revolt in the Eighty Years War, had grown accustomed to tobacco products grown in Spanish colonies and sought their own plantation and trading lands for it. This is likely not a fully accurate representation of Dutch desires for colonial land of their own, but regardless, beginning in the late $16^{\text {th }}$-century, the Dutch established a number of forts between the Amazon and Orinoco, usually surrounded by small plantations of tobacco, coffee, and cotton. Early Dutch forts were typically not immediately adjacent to the ocean, but several miles upstream on many of the rivers in the area where they could more easily be defended from Spanish and English attacks ${ }^{8}$. Through a series of attacks, many of these forts would fall into British, French, and Spanish hands, but were usually brought back under Dutch control fairly quickly.

In 1613, Spanish colonials from the Caribbean isles attacked a group of Dutch settlers along with their Carib trading partners in a small fort on the Corentyne River. Despite their trade relationship, the two groups engaged in and experienced the battle in very different ways. The Dutch settlers died with their fort, while their Carib companions

${ }^{8}$ An earlier work by Halliday (1837) suggests that Zeelanders had established a coastal fort in the mid- $17^{\text {th }}$ century, but this is likely either a typographical error in the text or a misunderstanding of the transfer of land from the Dutch West India Company to Zeelanders in the $18^{\text {th }}$ century. 
escaped (Rodway 1912). Around the same time, the Dutch settlement at Fort Kyk-over-al was established in what would become the Essequibo colony. Fort Kyk-over-al's longterm success (i.e. being lost briefly to the English and being repeatedly attacked by French privateers not withstanding) was, according to Rodway, due in part to a lack of coordinated response from Spanish colonials in Trinidad and Margarita (perhaps out of fear of Carib groups in the area, see Rodway 1893) and in part because it was an early outpost of the Dutch West India Company and thus a useful trading post between South America and the Antilles, including as a site for illicit trade with the Spanish. This is only a partial story of Dutch-Carib relationships, however. While it is true that the Spanish did not coordinate an attack on newly established settlements in Essequibo, perhaps equally important in Dutch success was the unique relationship Dutch settlers in that area had established with Carib groups, a point hinted at but never expounded upon in Rodway's historiography of the region.

According to Neil Whitehead (1990), the Dutch established a variety of important trade relationships with different Carib groups, usually trading access to European goods in exchange for military assistance (including the capture of enslaved people attempting to escape) through a process known as ethnic soldiering. James Whitaker (2016) expands upon this history, noting the multiple configurations of Dutch-Amerindian relationships which included ethnic soldiering but also less hostile trade relationships. These relationships were important to maintaining life in Dutch colonial Guyana. As with other Dutch colonies the actual number of Dutch settlers was small and made up only a minority of the European settler population (Oostindie 2012). Those interested in coming to the region to establish plantations were largely from other European countries and 
were willing to work the land and trade with the Dutch in exchange for the security of both their land and their human property.

In the early years of Dutch colonization these trade relationships centered around the movement of native materials — such as annatto — as they sought to establish a trade network in South America and the Caribbean. During this period, Dutch-Amerindian relationships were useful for the Dutch in that they provided them not only with a trading base but also a source for the goods desired in Europe, particularly annatto (Whitaker 2016). As these trade relationships developed so did Amerindian enslavement in Dutch colonies. Though officially prohibited, Amerindian enslavement appears to have occurred as early as the 1640 s and intensified to the extent that, by the 1680 s it needed to be regulated as prohibition was no longer working (Whitaker 2016; Whitehead 1988). With regulation came codification of the rules of enslavement and in particular the fact that Dutch could only enslave Amerindians who had already been enslaved by other Amerindian groups (Whitaker 2016). Intensification of annatto production combined occurred simultaneously with intensification of Amerindian enslavement and the Amerindian slave trade (Whitaker 2016; Whitehead 1988).

While the Dutch may not have been interested in establishing themselves as settler colonials in the Caribbean-Atlantic region like the neighboring Spanish and Portuguese, they did find it necessary to become a political power in the region. Unlike the Spanish, who treated all Carib people as a homogenous group, the Dutch recognized divisions within Carib society that they could exploit for their own benefit. Dutch colonizers forged relationships with individual Carib leaders and acted as arbitrators in local inter- and intragroup Amerindian conflicts, securing the loyalty of some groups and 
a source of enslaved Amerindians from others through the exploitation of intra-ethnic conflict. As a result, Dutch trade agreements fractured the unified Carib ethnicity that had been established and enforced by the Spanish and, in the process, produced several distinct ethnic groups with a new set of politics and a new hierarchy based primarily on access to the Dutch themselves. These were thus not organic or ad-hoc trade relationships that existed for the sole purpose of slave capture and marginal trade, as Rodway and Rodney seem to suggest, but deliberate political maneuvers meant to insert Dutch influence into local Amerindian politics. As such, the relationship between Dutch and Amerindian populations were not static either but rather changed as part of the dynamics of a broader system of colonization in the region.

Within 50 years, these new ethnic divisions had overridden wider ethnic loyalties, with different Carib groups fighting each other, allying with Arawak groups, and acquiescing to Dutch interventions into Amerindian politics to build and maintain European trade alliances (Whitehead 1990). The Dutch had effectively created a new geopolitics for the region based not on a typical settler colonial arrangement which murdered, enslaved, or displaced Amerindian groups in an effort to settle large tracts of land, but through incorporating them into the very system of trade that they were most concerned with. Conversely, the burgeoning colonial sugar industry in Essequibo (which was not just Dutch but also British, French, and to a lesser degree German), important to both Rodway's and Rodney's historiographies, was less important to the profitability of the colony than Amerindian trade agreements until at least the mid-eighteenth century. In one example, the Dutch commander Amos van Groenewege would have likely lost control of the colony if not for his marriage to a Carib woman, which settled a dispute 
between Carib and Arawak groups living in the region by equalizing the access each had to colonials (Whitehead 1990).

However, by the mid- $18^{\text {th }}$ century with the growth of other industries beyond indigenous trade and the true start of widespread colonization, these relationships took on a new character where Amerindian enforcement became a key factor in the success of the coastal colonies. The Amerindian slave trade became more profitable than the annatto trade and co-existed alongside the African slave trade. Since the only source for enslaved Amerindians were other Amerindian groups, inter-ethnic fighting intensified and certain Carib groups took on a position as enforcers of colonial laws and boundaries, highlighted by their role in the 1763 Berbice Slave Revolt which, had it been successful, would likely have collapsed the nascent coastal plantation economy.

The growth of the plantation economy in the Dutch colonies corresponded with an increase in the enslaved population working in it and — unsurprisingly — attempts to escape it. Having a stake in this system, those at the top of the Dutch-Amerindian hierarchy began capturing or killing people escaping enslavement, destroying maroon camps, and generally acting as a colonial police force. By 1763, they had become nearly fully integrated into this role, receiving firearms, collars, and badges for taking part in the suppression of the rebellion (Whitaker 2016; Whitehead 1988; 1990) and by the 1770s this relationship became a formal means by which the Dutch sought to protect their South American colonies from the internal threats posed by revolting enslaved people as well as the external threats posed by invading colonial forces during the Napoleonic wars (Whitehead 1988; 1990). In this way, Dutch-Amerindian relationships — both as slaves and as enforcers of the system of slavery — were a keystone in success of plantation 
colonial settlement on the coast, paving the way to the establishment of the modern system of plantation agriculture and the political, economic, and social precarity that would come with it.

Power, Politics, and the Taming of the Wild Coast

The Dutch were not alone in their attempts to colonize the West Indies. Prior to the start of the War of American Independence, British trade in the Caribbean relied heavily on trade with the American colonies, where sugar, molasses, and rum produced in the island colonies could be traded for lumber, cotton, and foodstuffs produced in the American colonies (Carrington 2002). With land as a precious resource and with Dutch and Amerindian enforcement of slavery, island planters began establishing sugar and coffee plantations in the burgeoning South American colonies of Essequibo, Demerara, Berbice, and to a lesser extent Suriname and Cayenne (modern French Guiana). As this occurred, British (along with Dutch, French, and German) planters began building their settlements downstream before eventually settling the coastal area in the mid- $18^{\text {th }}$ century $^{9}$. To support this new growth, colonizers began establishing cities to facilitate trade closer to the mouths of the rivers, including Stabroek (now part of central Georgetown), established by the French at the mouth of the Demerara River in 1782 and New Amsterdam, established by the Dutch at the confluence of the Berbice and Canje

${ }^{9}$ One example that illustrates this movement north to the coast is Cummingsburg. Now a part of central Georgetown and home to many of the country's government offices, it was established as a coffee plantation in the 1760s by a French planter named Jaques Salignac. 
Rivers in the 1790s. To protect these lands from flooding, planters developed a system of dykes, dams, and earthen sea walls that channeled water into a series of canals, the outflows of which were managed by the Dutch and are today called Canals No. 1, No. 2, and No. 3.

This new system of drainage doubled as a means for irrigating sugar cane fields as well, with canals able to drain into the fields and exit through sluice gates (locally called kokers) into nearby rivers or the ocean. With each plantation being roughly rectangular in arrangement, the setup was fairly simple (see Figure 2). Along the banks of the river or the coast was the front dam, usually an earthen levee built behind the mangroves that could double as the high road connecting plantations to the cities. The plantation village was behind this, sometimes separated from the fields by a road (or, later, railway embankment) also used to transport goods between plantations and to the ports and markets. At the rear of the property was another earthen levee called the back dam. Along either side of the plantation, demarcating the property lines, were canals which drained either to the front dam, the back dam, a larger canal that drained several plantations, or a combination thereof. The middle of the plantation included a road that allowed access from front to rear, with canal trenches on either side. These canals were also used to move cut cane from the fields in the rear to be processed at the front of the plantation near the village. In some cases, in order to provide direct access to the sea, mangroves were removed resulting in the collapse of the sea wall and a flooding of the field (more details on this in later chapters.) 


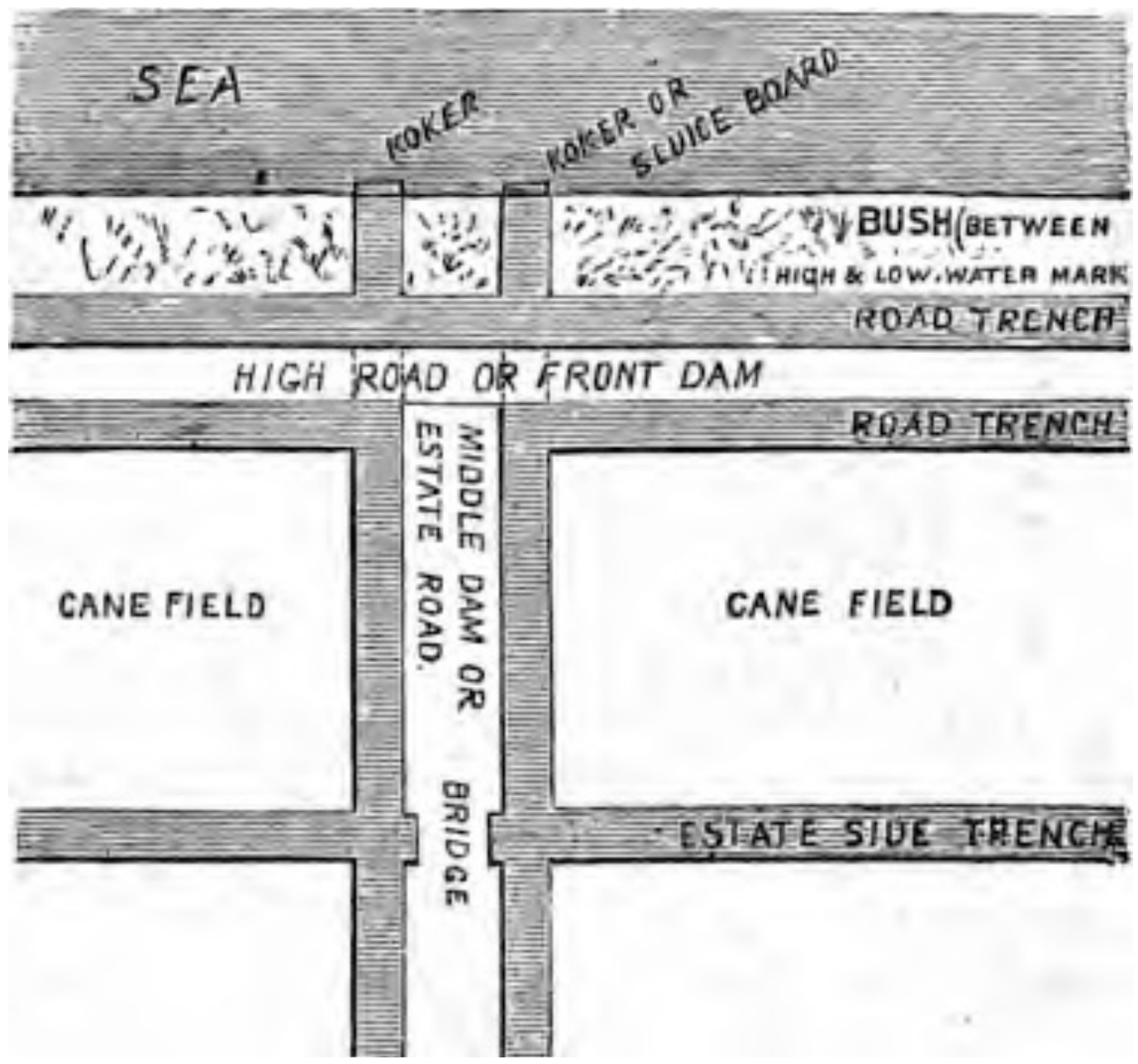

Figure 2 - A typical plantation layout (from Jenkins 1871)

Besides occasional feelings of resentment by planters resulting either from perceived slights by Dutch colonial administrators or issues with neighboring plantations, this system developed fruitfully until the outbreak of the War of American Independence. Shortly after the war began, the Dutch West India Company supplied arms and munitions to American revolutionaries in exchange for tobacco and other American colonial goods, which were laundered to Europe through Dutch trading posts in violation of the Navigation Acts. With the outbreak of the Fourth Anglo-Dutch War in 1780, the British 
used their superior naval fleet and the movement of the Dutch centers of commerce to the coast to seize control of the Dutch mainland colonies of Essequibo, Demerara, and Berbice in 1781, though they would lose control of Demerara to the French the next year and not take final control of them until the end of the Napoleonic Wars in 1813.

Under British rule, coastal drainage and irrigation saw its first regulation. The system of individual planters working without coordination to drain, irrigate, and protect their lands from flooding was only marginally successful and made coastal floods difficult to manage. Likewise, with the administrative center of Essequibo and Demerara moved to Stabroek, the area saw large population growth in the form of colonial administrators and traders who would not need (nor likely desire) to live on plantations, bringing about the development of specifically urban neighborhoods, such as Kingston (the site of former British and French forts at the mouth of the Demerara river), and the transformation of some plantations into residential and administrative blocks, such as Cummingsburg in central Georgetown. These new residential districts needed to be drained and protected from flooding as well and could be negatively impacted by the actions of planters on nearby lands. In the 1780s, under French control, enslaved Africans requisitioned from nearby plantations were forced to dig two large, east-west canals to ease flooding in these emergent residential areas.

\section{Conclusion}

It is clear that Dutch settlement of the coast in the $17^{\text {th }}$ and $18^{\text {th }}$ centuries, and as a result the canalization and damming of the region for the creation of a colonial agrarian system, would have been much more difficult without coastal Amerindian's provisioning 
of material support for Dutch colonial efforts. Rather than settlement on a virgin coast ready to be modified by European achievement, as has been suggested by other histories of the region, colonial success rested on alliances with a variety of existing coastal Carib (and to a lesser extent Arawak) groups which not only helped to enforce slavery in a land rich part of the world, but which also helped to establish a much larger military presence which aided in their defense against threats from both foreign militaries and privateers.

Early Dutch-Carib trade relationships established the political and economic conditions for coastal settlement in what is today Guyana. Through the founding of the colonies of Essequibo, Demerara, and Berbice - made possible in part due to the use of Carib ethnic soldiering - the insular system of Caribbean sugar and coffee plantations was able to spread to the mainland bringing with it the social, political, and economic components of the broader colonial project. This includes both the racial politics of slavery and indenture and the authoritarian systems of governance which these necessitated. As more planters moved to the region, they modified the physical environment to better suit the production of sugar, taking advantage of the nutrient rich coastal soils. Despite setbacks, including the loss of a number of sugar plantations, this system flourished with the establishment of hundreds of new plantations dedicated solely to the production sugar. This growth required the development of a system of flood protection, drainage, and irrigation that transformed a highly dynamic coastal mangrove forest and swampland into a highly-managed human-environment, modified to suit the needs of a colonial agrarian economy and providing the groundwork for the continued production of precarity that governed colonial and postcolonial life for the vast majority of coastal residents. When a series of wars broke out between the French, Dutch, and 
English, the shifting power dynamics required a change in tactics. Under English rule, ethnic soldiering was no longer a requirement for the defense of the region and coastal indigenous populations were displaced to make way for the growing agrarian system. While the Dutch utilized slavery for their plantation system, the magnitude of the sugar trade under British control brought about a massive shift in the population dynamics in the colonies. Rapid population growth in the coast required changes to the existing system of drainage and irrigation, requiring a more complex arrangement, often, as argued in the following chapters, to the detriment of the country's laboring populations. 
CHAPTER 2 - “A MILD DESPOTISM OF SUGAR”: RACE, LABOR, AND WATER MANAGEMENT

Mr. Trollope's ${ }^{10}$ description of the government of British Guiana as a mild despotism tempered by sugar, would be more correct if altered to "a mild despotism of sugar." Sugar is the ambition, means, and end of nearly everything done in the colony. It gives aim to the energy of the trader, animates the talent of the lawyer, prompts the research and skill of the doctor, and sweetens the tongues as well as the palates of the clergy.

- $\quad$ Edward Jenkins, The Coolie, His Rights and Wrongs $(1871,58)$

\section{Introduction}

Since its establishment as a British colony in 1814, sugar production has been the primary economic motivator in Guyana (Thompson 2006). As with other colonial locations, this economic position gave rise to social and political order and disorder centered on the continued successful production of the commodity. While working as the postal inspector in the colony, the Victorian novelist Anthony Trollope described the

${ }^{10}$ Anthony Trollope, a Victorian-era novelist who toured the colony as postal inspector in 1859. The original quote can be found in his recounting of the trip in The West Indies and the Spanish Main. "The form of government is a mild despotism, tempered by sugar. The Governor is the father of his people, and the Governor's wife the mother. The colony forms itself into a large family, which gathers itself together peaceably under parental wings" (Trollope 1859, 170). 
political situation in the colony as a "mild despotism tamed by sugar," in which it only the needs of the sugar industry could temper the authoritarian goals of the planters and sugar industry (Trollope 1859, 170). A few years later, during a study of the conditions in which indentured laborers were being forced to live and work, Edward Jenkins offered a corrective, stating instead that it was more accurately a "mild despotism of sugar," in which sugar and its continued success was the driver of life on the coast at the expense of all other options (Jenkins 1871, 58). Beyond the role of the plantocracy in guiding colonial policy, the development and protection of the sugar industry was the principal concern of the government. In this chapter, I draw on archival research conducted between 2015 and 2017 at the National Archives in London, UK to examine the broader social politics of this "despotism of sugar." I utilize a variety of letters, memoranda, and minutes between colonial administrators and sugar estate representatives as well as newspaper commentaries related to sugar and flooding in order to understand the ways in which sugar production and the water management infrastructure that made it possible affected labor and race relations in the colony, acting as both a means through which colonial politics were enacted and as a form of colonial governance in itself. This is done through an examination of the legislation surrounding the construction and especially the maintenance of infrastructural systems. I analyze the discourses surrounding why maintenance schemes were enacted as they were in order to understand maintenance not as a means to correct an objective failure, but instead to maintain "the social and political relationships in which that object is embedded" (Barnes 2017: 3).

While much can be said on race, labor, and water management during colonial slavery, the focus of my analysis is on Guyana's post-emancipation period. The reason 
for this is two-fold. First, there exists a significant body of literature on sugar and slavery with much less emphasis on sugar in the post-slavery period. Centuries of writing on the subject have produced detailed accounts on the conditions and resistance of enslaved Africans (Viotti da Costa 1997), the role of sugar and slavery in the development of capitalism (Mintz 1985; Williams 1944), and the role of the sugar industry in the abolition of the slave trade (Carrington 2002), to name only a few, while considerably less has been written about the ways in which the commodity continued to be a driving force in the Caribbean long after both the end of slavery and perhaps after the crop's economic viability had come to an end. Second, while writings on labor relations and the sugar industry in the post-slavery era exist, including some with a focus on Guyana (e.g. Rodney 1981a; Thomas 1984), the role of water management infrastructure as a technology of government (see Kooy and Bakker 2008) and an active producer of socioecological precarity within this system has not yet been included in these analyses. This is a significant omission from the literature. In their respective examinations of sugar and labor in Guyana, Adamson (1972), Rodney (1981a), Thomas (1984), and others treat infrastructure as a background upon which colonial relations were structured rather than as a structuring object within the colonial system itself. In this way, the drainage and irrigation and sea defense systems have been treated as simply another means by which the exploitation of the working people of the country could be seen and quantified. While this is certainly true, I argue that water management as a whole was one of the principle means through which colonial governance occurred, directly shaping experiences of colonialism and legislating life in the colony in order to produce a very specific colonial subjectivity rooted in black (and later Indian) laborers' role in a white 
plantation economy. It served as an avenue not only for providing general economic stability but also for population control. Importantly, I argue in this chapter that water management and flood control infrastructure projects were used as a means by which colonial actants produced and reproduced the economic precarity of African village laborers and to suppress the wages of those who remained in the broader sugar economy. In this way, control over the floods and thus also their impacts served a means of reducing the potential resilience of Guyana's black working classes in a way that - as I show through the following chapters - had long-term impacts on coastal resilience more generally while simultaneously producing a resilient sugar industry on the backs of the working classes answering an important questions in resilience narratives: resilience of what and for whom (Cretney 2014). This can be applied more broadly to understand the ways in which control over infrastructure acts as a means by which governments can produce precarious subjects.

I begin with a brief theoretical overview of the "politics of things." Here, I review the existing literature on the many ways that artefacts are used to affirm and reproduce existing systems of power in capitalist political economies as well as the ways in which these systems draw on racialized bodies to act as vehicles for this reproduction. Drawing theoretically from political ecology, environmental history, and science and technology studies, I use two case studies to show how infrastructure construction and maintenance carries with it a particular set of politics related to prevailing socioeconomic (rather than strictly geophysical or ecological) characteristics. First, I argue that flood events are not necessarily the result of colonial negligence but were actively used to reincorporate emancipated Africans back into the plantation economy after the urbanization and 
proletarianization of black labor on the one hand and the village movement on the other significantly reduced the number of workers willing to work in the sugar industry, threatening its ability to survive various economic recessions and depressions. Next, with the sugar industry undergoing financial struggles in the early-to-mid- $20^{\text {th }}$ century, I show how relief projects, including the construction of drainage and irrigation and sea defense works, was used as a means of economic support for the large and growing number of unemployed in the country during economically down years without fundamentally changing their position in society and denying them the possibility of leading what might have been resilient lives.

Through a series of policy changes and direct acts of legislature, the crown was able to sustain the sugar industry through the promotion of these works without ever providing direct financial support to planters. In fact, in at least one case, planters profited off of these policy changes and the dire financial situation of the colony. I connect these temporally disparate events in order to argue that planters, with the implicit support of the colonial government, used flooding to mobilize a reserve army of labor economically located outside the sugar industry and spatially located in African villages. Moreover, as I will make clear, there was a racialized component of this governance. While there were many Indo-Guyanese workers on sugar plantations beginning in 1838, the number was often not sufficient for cane harvesting season and workers could not work simultaneously in the fields and on infrastructure projects, especially as indenture contracts ended and a portion of Indo-Guyanese workers began moving away from the plantation system themselves. Thus, Afro-Guyanese, whether seeking new forms of economic autonomy or working as an urban proletariat in Georgetown, were the target of 
many of these plans to increase labor productivity without increasing costs. I draw specifically from Marx’s (1887) idea of a "reserve army of labor" to explain this situation, but I also expand upon it by making it clear the ways in which this "reserve army" had a racial character affected by the broader colonial system in which it was operating.

Infrastructure, Governance, and the Politics of Things

In one of the seminal essays of science and technology studies, Langdon Winner (1986) asked a simple question: “do artefacts have politics?" Winner argues not only that they do, but that "The kinds of things we are apt to see as 'mere' technological entities become much more interesting and problematic if we begin to observe how broadly they are involved in conditions of social and moral life" (Winner 1986: 6). Technology, in the broadest sense of the term, serves a mediating role in everyday life not only through the ways we interact with it, but also by establishing clear boundaries of who belongs in particular spaces at a given time. This techno-material culture, including in this case the dykes, dams, kokers, and pumps meant to keep coastal Guyana dry (which, drawing on Prichard 2011, I refer to collectively as enviro-technical systems) and inline with postanarchist conceptualizations of diffuse power, "embody specific forms of power and authority" (Winner 1986: 19). This power and authority comes from larger systems and structures of power, they are reflections not only of the society in which they exist but also that which built it. This confluence of power and material culture may be seen as accidental or exploitative (i.e. they create a condition which can be taken advantage of but were not designed to meet any particular goals), but it is worth asking whether these 
creations were designed to serve any purpose prior to those professed in their design and to what extent their designs continue to shape coastal lives.

In the decades since Winner posed his question, a large body of scholarly literature has developed around questions of the power of artefacts, particularly around water infrastructure. Timothy Mitchell (2002) argues that enviro-technical systems were another site in which colonial and postcolonial governments demonstrated not only their technological, but also their economic power. The ability to "tame" nature in the name of capitalist production was the sign of a modern and efficient state, in which technology was the means by which the economy could survive and thrive. Katie Meehan (2014: 216) has shown how water infrastructure acts as sites for building and resisting state power, in turn becoming spaces "reflective of deep sociospatial inequalities." Envirotechnical systems were likewise created for a world that will cease to exist long before that technology is no longer useful for its stated purpose, but those systems maintain the unequal spaces which they initially produced (Winner 1986; Stoler 2016). Political conditions change, economic systems rise and fall but the material culture embedded in enviro-technical systems persist.

The persistence of political and economic conditions embedded within water management is also in line with Sara Pritchard's (2012: 592) argument for what she terms "hydroimperialism," in which "water management practices both revealed and reproduced unequal power relationships based upon an expansionist mentalité." In the cases below, the expansionist ideology that supports unequal power relationships is tied directly to the establishment of a colonial agrarian economy that required copious amounts of inexpensive labor not only to work in the cane fields and factories during 
planting and harvesting season, but also to construct the system itself. While Guyana's coastal plain contains nutrient rich soils ideal for cane production, it features very little geographical prominence and poor natural drainage resulting in heavy flooding unless altered by the drainage and irrigation system. The construction and maintenance of this system required thousands of enslaved and later poorly paid African laborers to move thousands of tons of earth (Rodney 1981a). Even as the political and economic system changed from one based on slavery to one based on "free" labor, the material conditions set in place by the construction of Guyana's coastal water management system were reproduced even (and especially) when a portion of those lands no longer served the purposes of a colonial, agrarian political economy. This is reflected in another term developed by Pritchard (2012), "hydrocapitalism.” Through hydrocapitalism, water management practices helped realize and reproduce capitalist arrangements, deepening the already uneven terrain of political and economic power in colonial spaces and working to produce a form of socioecological precarity that could only be reduced through continued engagement with the system that produced it, in some ways echoing Evans and Reid's (2014) criticisms of many of the current calls for increased resilience. As I will demonstrate in the two case studies below, water management infrastructure played a significant role in maintaining British Guiana's sugar industry, and thus the very lifeblood of the colony, both when it was flourishing and when it was floundering not by protecting it from encroaching water, but by providing spaces for additional low-paid black labor. 


\section{Flooding, Labor, and the Sugar Industry in East Coast Demerara}

By the 1880s, when the story of flood control as governance begins in earnest, British Guiana had already undergone considerable political and economic shifts since its establishment as a British colony, related in part to the end of global colonial warfare, the abolition of slavery, and the rise of the industrial revolution but also due to changing political, economic, and geophysical conditions along the coast. Although having occupied the territories that make up present-day Guyana since the late $18^{\text {th }}$ century, official British reign would not begin until 1814 when the Dutch ceded the colonies as part of the Treaty of Paris at the end of the Napoleonic Wars. As shown in Chapter 1, under the Dutch, administration of the colonies was somewhat laissez faire, with planters enjoying considerable freedom and limited controls on trade but also bearing much of the burden of protecting and maintaining drainage, irrigation, and flood defense works. The Dutch oversaw the construction of only three of the colony's canals, all along the Demerara River, with the rest having been built by enslaved laborers at the behest of planters from a variety of European colonial origins.

Under the British, however, there was a distinct change not only in the form of governance but also in the logic applied to it. While the Dutch saw their role as trade facilitators for an ad hoc collection of tenants - many of whom were not Royal Dutch subjects - the British saw themselves as colonizers proper, who ruled over both people and the land. In order to enact these changes, they sought to centralize the system of governance along the coast and bring into being what they considered a more ordered state of affairs, one in which British colonial law could be implemented and enforced. A major part of this was the centralization of flood control efforts, most especially sea 
defense works. A history of sea defense in the country produced for the Colonial Office in the 1920s shows that early as 1794 , while still technically occupying Dutch territories, the British became concerned about coastal erosion at Fort William Frederick in what is now Block Alpha of the Kingston Neighborhood of Georgetown ${ }^{11}$. The Fort, lying along the eastern bank and coast of the estuary of the Demerara River, was a key strategic site for the defense of the emerging coastal city and its protection was vital to British success in the region. Dutch settlement of the Guyana territories occurred upstream, where people and property could be easily protected with assistance from the river. As the population moved north to the coast, many of the valuable agricultural assets would be left unprotected without some kind of defense structure in the region. The Fort provided not only a battery which could protect both the river inlet and the sea face, but also supported a much larger military presence on the coast more generally. The battery was built on and protected by a short sea wall itself built atop the muddy coastal land. However, between the outflow of the Demerara River and movement of the Guiana Current, processes of accretion and erosion in the area were so severe and happening so rapidly, that beaches would form in front of the fort as the result of mud and silt deposits only to be completely washed away within a year, taking the soil supporting the wall with it.

By 1810 , there was a serious need for construction and maintenance of the defenses but there was significant colonial confusion with regards to who should pay for them ${ }^{12}$. Severe flooding in 1804 devastated parts of the coast and it appeared that it would

${ }^{11}$ CO 111/680/10, enc. 1, The National Archives, UK ${ }^{12}$ Ibid. 
happen again. British Guiana did not yet exist and Demerara-Essequibo technically remained a Dutch territory being occupied by British forces. The Kingston area was under the control of the Colonial Office, but the Fort and its northern face were under the purview of the War Office. Nearby plantation lands were held privately by individuals who were responsible for their own drainage, irrigation, and sea defense systems. Because funds for major colonial works projects were often limited during war time, especially for areas that were not yet colonies, the Colonial Office and the occupying government "refused to contribute to the protection of these lands." 13 While minor efforts were made to protect the land, including the building of breakers in an attempt to slow erosion of current earthen defenses and doing maintenance on the existing, but failing sea defense works, there was no systematic construction or maintenance of sea defenses and it was only a matter of time before this piecemeal system collapsed.

With the end of slavery in 1834, planters were granted four years to hire the formerly enslaved people on their plantations as "apprentices." Under apprenticeship, emancipated Africans experienced a kind of indentured servitude where they worked in the fields in exchange for food, shelter, and a small wage. When apprenticeship ended, many, though certainly not all, left the plantation system and sought a life outside of it, in part through the creation of what would later be called the African Village Movement (Moore 1987; Young 1958). This period saw formerly enslaved Africans pool their economic resources and purchase abandoned plantation lands on which they could settle

${ }^{13}$ Ibid. 
and grow their own food and crops, relying significantly less on the plantation system and colonial government in order to survive in the colony (Haynes 2016; Young 1958). According to sociologist Brian Moore (1987, 93), "it was the newly established village communities along the coast which provided the institutional framework for organizing the black and coloured section into a coherent corporate group. They were the vehicle by which the disenfranchised majority could develop the organizational structure and leadership with which to challenge the political and social dominance of the white minority."

The development of villages thus served as a significant threat to white social domination through the threat they posed to the survival of the coast's agricultural economy. However, removal from plantation life did not, however, mean removal from the sugar industry and a number of Afro-Guyanese sought work in industries ancillary to the plantation economy (e.g. shipping; Rodney 1981a; 1981b; Thompson 1987). To offset this loss of labor, the government established an official system of indentureship which, between 1851 and 1917, saw 226,723 South and Southeast Asians brought into the colony and provided with food and shelter in exchange for their labor on the sugar plantations (Follett-Smith 1954). However, as indentureship ended, many of these workers also left the plantation system, moving to villages alongside Afro-Guyanese or to ones specifically established for the expansion of the sugar and rice industries along the coast as part of a new land settlement scheme (see Greenidge 2001).

In the interceding years there would be a number of small breaches of coastal sea defenses, including floods in the African village of Plaisance in 1847 that inundated the front properties as far as a mile back from the sea wall and in 1849 that saw villagers 
petition Governor Barclay to not levy assessments against their property for damages to nearby lands as a result of the breach of the Plaisance front dam (Haynes 2016). It was not until 1855 , when flooding directly threatened colonial lands and the sugar plantations that supported the colonial economy, that things came to a head. The Great Kingston Flood, as it is now known, caused breaches of coastal defenses that affected not only the emerging capital city of Georgetown, but also many of the plantations that would eventually become integrated into the city as they failed and closed, including what would eventually become the squatter settlement of Sophia, the University of Guyana, and Ogle Airport some 10km away from the center of the capital. With such a large portion of the coast inundated, including both private and colonial lands, the question of how to manage floods become one of critical importance for the continued governance of the colony.

When the flood waters receded, new construction on sea defense works began on all of the colonial coastal lands. In 1855, construction of a new permanent sea wall began at the battery of Fort William Fredrick and continued to the neighborhood (then village) of Kitty by the end of 1874 . Meanwhile, planters and nascent villages were still largely left to construct and maintain their defenses or to pay the government for the works at a later date via loans, costs which planters argued they could not afford to bear after emancipation and which villages that were largely self-sufficient were in no economic condition to pay. In 1856, the Village Management Bill was passed, providing the first legal definition of a village and outlining their responsibility in relation to the colonial government and the estates. It also created the legal infrastructure for the requirement of all independent villages to maintain their drainage and irrigation systems as well as their 
sea and river defenses (and other infrastructure) or risk losing their land entirely. While Kingston and the colonial parts of Georgetown were now well protected, nearby areas were still exposed to severe threats of coastal flooding. Environmental engineers working on the system of sea defense warned that these weaker areas could cause significant distress to other parts of the colony. The situation became so dire that, in 1883 , the government was forced to enact further legislation placing the legal onus of construction and maintenance of all sea and river defenses as well as all estate back dams on the proprietors and villagers while shifting the responsibility for kokers, pumps, and other large drainage infrastructure to the government, paid for via taxes. Failure to maintain defense works could result in legal action including the loss of the plantations and for the villagers the loss of the entire village, which would usually then be sold and incorporated into an adjacent plantation (Adamson 1972; Young 1958).

The severity of this law was justified by the fact that the failure of one estate to maintain the works also threatened the entire coast with inundation. If that was the case, however, sea defenses should be considered a colonial matter and handled by the colonial state, at least according to some of the smaller estates remaining on the coast. In April 1886, estates from the West Coast Demerara region argued exactly this, stating that sea defense should be a colonial matter and arguing for it in the Court of Policy. At least one member of the court agreed with the estates and stated that "small capitalists, individual proprietors, were not able to struggle with the sea defenses of the colony. No individual owner of a small property could run out a strong and expensive sea wall, where there was much granite work" (Daily Chronicle 1886). However, change would come slowly. Meanwhile, a system was established where estates and villages would be able to draw 
on loans-in-aid from the colonial office and government to either pay for construction themselves or to pay the Public Works Department to cover the costs if they could not do manage it themselves.

So dramatic was the flooding during this period that, in 1929 a member of the Colonial Office described the history of Sea Defense in British Guiana prior to 1883 as "a continuous fight between the landed proprietor and the sea, in which the proprietor was usually defeated." ${ }^{14}$ Now codified into law with punitive measures, proprietors including villagers - were forced to take pre-emptive action. The new costs imposed by this legislation found smaller planters seeking to extend the cane season by modifying the amount of water in the drainage system to allow for a prolonged cultivation and to find ways in which they could lower labor costs during cultivation and processing while the larger estates and sugar firms lobbied for continued preferential treatment to insure the economic viability of the British Guiana sugar market.

It is within this context that Plaisance and the nearby village of Beterverwagting flooded in 1886 and 1887. The village of Plaisance was, in the late 1880s, sandwiched between two sugar estates, Goedverwagting and Sparendaam, with which it shared side dams and a back dam meant to protect all three from savannah floods. Utilizing the existing network of drainage and irrigation established when the land was used as a cotton plantation, villagers produced subsistence and market crops including plantains, cassava, yams, and other tropical staples, allowing them to supplement wages earned on

${ }^{14}$ CO 111/680/10 enc. 1 , The National Archives, UK 
the sugar plantations and in the city, diversify their local economies, and live with at least somewhat less reliance on the colonial agrarian economy established in the $17^{\text {th }}$ century ${ }^{15}$. In January 1886, heavy rainfall along the East Coast Demerara region caused the water in the canals to rise, eventually inundating the village. While Plaisance had experienced flooding before, the causes had appeared to either be anomalous (e.g. the failure of a defense work due to erosion or wave action) or just part of coastal life, afflicting much of the adjacent coast with the same struggles. In 1886, villagers began to see the floods in terms of racial power. The large steam-powered mechanical pump, which was meant to drain the village in the event that gravity drainage was unfeasible, was left inoperable due to the poor condition of its boiler resulting from a lack of maintenance by the colonial government. While plantations and villagers were required to maintain their own drainage and irrigation and sea defenses, as outlined below, villagers in Plaisance opted to pay a maintenance rate to the colonial government in exchange for assistance. In a letter to the editor of the Daily Chronicle dated February 1st, an anonymous villager asked in anger, "how must the people undertake again to put their labour in the ground when the white man allows negroes' plantains and cassava to be inundated and thus suffer?" (Ratepayer 1886).

${ }^{15}$ In the case of the villages of Beterverwagting and Triumph, however, villagers themselves entered into the sugar market. This would later lead to a recommendation that all villages be encouraged to grow sugar rather than subsistence crops in order to have a higher income to pay for the repair and maintenance of defense works. (Letter from Edward Denham to Phillip Cunliffe-Lister, $7^{\text {th }}$ May 1934, CO 111//720/9, The National Archives, UK) 
The following year, flooding struck Plaisance again and villagers again used the Daily Chronicle to voice their frustrations and, this time, to demand direct compensation for the crops that were destroyed in the flood. Villagers blamed this second major flood explicitly on the manager of the adjacent sugar estate of Goedverwagting. They maintained that the estate manager modified a stop-off used to hold back conservancy waters at the rear of the plantation in order to extend the cultivation of sugar in his fields (Truth 1887). With the stop-off not functioning as intended, a period of heavy rainfall caused additional pressure to be placed on the Plaisance village back dam which eventually gave way; flooding their fields and destroying acres of crops used for subsistence. Other villages in the East Coast Demerara region, including nearby Beterverwagting were also deeply affected as the storms caused a breach in their sea defense system which they could not sufficiently repair on their own. The result of this was the temporary dislocation of villagers on the East Coast who did not have a dry place to sleep as well as a steep decline in the availability of plantains, a staple food in the diet of the country's black laboring population (Pro Bono Publico 1887).

At least one villager demanded action, stating in an editorial letter to the Daily Chronicle that "the condition of the people wandering about, some huddled under the railway station, and in the open verandah, struggling to obtain a dry spot for human existence, exhibits a deplorable scene. All that the friends of the manager may say either by telegram to the governor or in the public prints in extenuation of his acts will not compensate in any way for the sufferings of the villagers" (Truth 1887). The response by white settlers was to say that the black villagers should give up their attempts at growing their own crops and take jobs on the plantation system as a means for recovering from the 
effects of the flood. Harry Garnett, from the nearby Plantation Nonpareil, shared the sentiment of many colonials, stating in his own editorial letter, "let another industry be started by all means, at which the black man will work for love or that can afford to pay him his own value, but in the mean time (sic) we are one and all dependent on sugar" (Garnett 1887b). Like the villagers of Plaisance a year prior, Garnett framed the issue of village flooding and the inundation of ground crops in racial terms. Elsewhere in his letter, he noted the role of sugar in dominating the politics and legislature of the coast, particularly around questions of flooding but dismissed village concerns because it was sugar, and nothing else, that would make coastal life successful, effectively denying Afro-Guyanese villagers the right not only to live outside of the plantation economy, but to even imagine alternatives to it. After emancipation, the low wages offered by the estates played a key role in the movement of Africans to other industries, including the village movement. That this would now be turned on them in times of need is unsurprising, but exemplary of the general abhorrence of the villagers by the plantation owners. Garnett characterized villagers working their own fields instead of his as lazy ${ }^{16}$, stating previously that "provisions during [the immediate post-emancipation period] were cheap and we naturally expected cheaper labour; but no, Quashie ${ }^{17}$ preferred to eat his

\footnotetext{
${ }^{16}$ The description of Afro-Guyanese workers as "lazy" has common ties to the plantation system in the US south and was just as persistent. Various letters during the 1930s economic crisis refer to Georgetown's black proletariat as lazy or "loafs."

${ }^{17}$ A generic, derogatory name for an Afro-Caribbean person, particularly in the anglophone Caribbean.
} 
own provisions that he had planted rather than work at a rate which did not enable him to sit down two and a half days out of the six" (Garnett 1887a) ${ }^{18}$.

The labor necessary for sugar production can take multiple forms. Workers are needed not only for planting and cultivation, but for processing in the factories and for general labor and maintenance of the plantations. Some of these jobs were necessary year-round and others seasonal. Indentures and former indentures provided the bulk of this labor force. Garnett (1887a) suggests that the ratio at Plantation Nonpariel was 2/3 Indo-Guyanese and 1/3 Afro-Guyanese at the best of times. Outside of the plantation system, Afro-Guyanese worked as a combination of yeoman and subsistence farmers and as an urban proletariat working in shipping and manufacturing in Georgetown and New Amsterdam. This racial differentiation of the classes was common throughout the Caribbean but was uniquely spatialized in Guyana where there was no white settler population to speak of and where historical conditions and a relative abundance of land led to the segregation of the racialized ethnic groups within the country (Hintzen 2004). When floods occurred, this race-class dynamic combined with systems of infrastructure to determine the lines along which people were affected. Already working in the sugar industry and living in the housing schemes associated with the sugar estates, IndoGuyanese were in some ways shielded from the long-term impacts of these floods as were Afro-Guyanese who had secure work in the cities. Those Africans who refused the

${ }^{18}$ Garnett's racist remarks were not limited to Africans. He had little positive to say about the Indian labor that was brought in to replace enslaved labor other than the fact they were obedient workers. 
industry and sought a new life altogether in the villages were often left homeless, starving, and generally helpless in times of flood, with no choice but to work in the industry for severely depressed wages. Even during the worst floods of this period, the sugar industry was mostly unaffected, even if inconvenienced. Instead, as shown above, free villages became sites in which severe floods had the greatest impacts to the general population. Estate managers and other colonizers recommended little more than for the country's black population to give up their desires for total emancipation from the plantation system and return to it in order to pay for the necessary repairs and for their own survival, regardless of what caused the floods themselves. With this loss of economic independence, colonial issues of race and flooding combined to govern the livelihoods of villagers and, by denying alternatives to acting as proletarian labor in planter capitalism, black life on the coast as a whole.

\section{The Sugar Industry, Infrastructure, and Relief Works}

Despite improvements in sea defense, coastal flooding in Guyana continued to be a burden to both plantations and villages, with neither able to afford the excessive costs associated with flood control works. A series of strikes in the sugar industry did not help the situation for the plantations who continued to expect and rely on low wages and poor conditions for workers and who refused to pay full prices for the needed works (see Rodney 1981a). In partial response to the worsening economic situation, in 1913 new sea defense legislation was passed that allowed the Government of British Guiana to provide up to 25 percent of the costs of sea defense for a plantation or village. This was funded by an acreage tax levied against all property owners outside of Georgetown, which was 
exempted from certain provisions of the ordinance due to its status as colonial land. This shift in policy from one in which only the city of Georgetown was protected by the state to one where the state played a role in all defense works was due in part to sea defense becoming a "colonial question." By the mid-1910s, the warnings from West Coast Demerara in the 1880 s became more obvious to the rest of the coast and it came to be increasingly clear that flooding in the region could not be left up to the actions of individuals, it required a more coordinated effort. In this regard, colonial officials drew an arbitrary line 10 miles inland from the coast and declared all lands between the ocean and that line as part of a number of sea defense districts. This new boundary, defined on the principle that "it is indisputable that, if the defences fringing the seaboard, were removed, the sea at high tides would inundate this area," provided the basis for the country's first integrated system of flood control. ${ }^{19}$

The logic of undertaking such a massive change in policy was clear: colonial records show that the government was already spending a considerable sum of money on sea defense and emergency works due to the failure of the estates and villages to do so to colonial standards. By taking it upon themselves, the colonial government could mandate and implement necessary changes and develop a tax scheme to fund them. ${ }^{20}$. A failed version of this policy, sent to the Court of Policy in 1921, stated this rather clearly when it said that one of the purposes of such bills was "to obviate along the whole 270 miles of the Colony's seaboard the recurrence hereafter of disasters such as those which have

${ }^{19}$ CO 111/680/1, enc. 1, The National Archives, UK

${ }^{20}$ CO 111/680/10 enc. 1, The National Archives, UK 
involved an expenditure of more than five million dollars ${ }^{21}$ during the past five years to protect permanently a seaboard of $521 / 2$ miles only." ${ }^{.22}$ In this way, the burden of the cost would no longer fall only on those adjacent to the sea, but to all who were protected by the system of sea defense whether directly or indirectly (although, notably, none of the proposed or passed bills dealt with the burden faced by past sea defense expenditures, only future works.) One major issue arises from this new arrangement, however. It would take decades for the taxes to raise the funds necessary for the construction and maintenance of new flood control projects. However, the works cannot take decades to build or the risk of catastrophic flooding remains. While fundraising through grants and loans from the Colonial Office was possible, the colony needed to find a way to cut costs in the short-term to reduce their loan burden.

Beginning in 1922, a series of coastal works projects took place and by 1923 the British Guiana government took over all responsibility for sea defenses ${ }^{23}$. Funded in part by the government and in part by proprietors (including both plantation land owners and local authorities), these works were meant to overhaul and generally improve agricultural productivity on the coast for both planters and small holder farmers (i.e. villagers and former indentures.) Over the six-year period of the projects, 22 new drainage areas were declared, 20 new drainage boards were established, and over 88,000 acres of newly

\footnotetext{
${ }^{21}$ British West Indies dollars, the local currency of Guyana and all British Caribbean territories at the time.

${ }^{22}$ CO 111/680/10 enc. 1, The National Archives, UK

${ }^{23}$ Minute 26 July 1929, CO 111/680/10, The National Archives, UK
} 
cultivatable land were now under a drainage scheme ${ }^{24}$ Within a decade of their completion, these projects were largely deemed failures due to a lack of maintenance and poor planning prior to their implementation ${ }^{25}$ The situation was so dire that $\mathrm{W}$. Jackson, a member of the West India Committee, one of the main legislative bodies for all of the British Caribbean territories, stated in a letter to then Secretary of State for the Colonies Malcom MacDonald "that the financial position of local authorities and proprietors concerned is at present so unsatisfactory and the present economic value of the lands included in the drainage areas so low that comprehensive measures of relief are necessary ${ }^{26}, "$

The villages were in particularly poor condition. In his witness testimony to the West India Committee, Gerald Case, an environmental engineer then serving as Director of Public Works and Sea Defences in British Guiana, suggested that the government take over all of the main drainage works in these locations because the villages themselves simply could not afford to maintain them, as shown in the extract of his expert testimony transcribed below.

Q: Do you consider the village communities are incapable of looking after their own drainage successfully?

\footnotetext{
24 "Drainage and Irrigation Works," CO 950/626, The National Archives, UK 25 Ibid.

${ }^{26}$ Letter from W. Jackson to Malcolm MacDonald, 25 March 1939. CO 950/626, The National Archives, UK
} 
A: They can certainly look after their internal drainage if given the particulars as to

levels and size of drains required.

Q: Why is it then, that you find drains now generally neglected?

A: The villages cannot raise enough money.

Q: I see. The question is one primarily of money, not of efficiency of working or

supervision?

A: No. They could look after the internal drainage perfectly well if they had sufficient funds. ${ }^{27}$.

Case thus argued for state intervention into the village drainage system as a means of easing the financial burden of the villagers, a burden born in part from decades of economic precarity stemming from their decision to live outside of the plantation system even in the face of colonial threats against their ability to do so.

Despite implementing changes meant to mitigate the impacts of falling sugar prices, by 1930, British Guiana was facing a full-blown economic crisis, with colonial officials seeking a series of grants and loans to cover current expenses. Part of these expenses included funds needed for the construction and repair of sea defenses. Sir Alfred Sherlock, chairman of Bookers Bros. McConnell \& Co. Sugar, spoke candidly about this situation by calling the British Guiana government takeover of sea defense works in 1923 a "colossal blunder," stating that "Our firm is very anxious indeed over sea

${ }^{27}$ Witness: Mr. G.O. Case, $4^{\text {th }}$ May 1939. CO 950/626, The National Archives, UK 
defenses. Government made a colossal blunder when sea defenses were put under the charge of the Public Works. I certainly do not wish to belittle in any way the Director of Public Works or his assistants, but I think it is very unfair to ask a man to undertake a job which he does not understand, and it is still more unfair to those who have to pay and who are dependent on the maintenance of their sea defences for efficient work." ${ }^{28}$ Meanwhile, directors from the sugar firm Sandbach Park and Co. offered to either loan the government money to repair a section of sea defenses on their land or to do the work themselves under the supervision and direction of the Division of Public Works, under the expectation that the capital invested in the project would be paid back at a later date with interest, an offer which the government accepted. ${ }^{29}$ The conditions were so bad in the country, the governor sent a letter to the Secretary of State for the Colonies warning that inaction could lead the rise of anticolonial sentiment during the country's local elections ${ }^{30}$.

The laborers for this new era of sea defense construction and maintenance came in the form of unemployment relief. The introduction of beet sugar in Europe and the United States caused the prices of cane sugar to drop significantly as early as 1883 (Follett-Smith 1954; see also Mintz 1985). This caused a number of smaller estates and factories to close as it was no longer profitable to grow sugar on a relatively small scale

${ }^{28}$ Extract from the Daily Chronicle $22^{\text {nd }}$ February 1930, "Economic Conditions in British Guiana Reach Critical Stage," CO 111/683/6, The National Archives, UK

${ }^{29}$ Letter to Lord Passfield, $12^{\text {th }}$ March 1930, CO 111/683/6, The National Archives, UK ${ }^{30}$ Paraphrase Telegram from the Governor of British Guiana to the Secretary of State for the Colonies, $26^{\text {th }}$ August 1930, CO 111/688/8, The National Archives, UK 
in the country ${ }^{31}$. Even then, the ones that survived did so primarily on the surge in sugar prices during the First World War and through Colonial and Imperial preference (FollettSmith 1954). In order to reduce their production costs, other estates changed their production schedules in such a way that allowed them to hire more workers while reducing the total cost of labor. In the case of one large estate, between 1928 and 1930 the total number of laborers increased by 90 while the monthly wages paid decreased by $\$ 34,000 .{ }^{32}$ The average wage on one estate went from $\$ 11.78$ per month to $\$ 9.24$ per month over this period while on another it went from over $\$ 15$ per month to $\$ 9$ per month. ${ }^{33}$ During this same period, producers increased production and expanded as they had a guaranteed market, but the prices for which were still so low that they refused to aid the producing populations. R.R. Follett-Smith, then-chairman of Bookers Sugar Estates Limited, stated as much noting that the prices during these preferential periods "did not permit improvement of living conditions or of factory equipment" but did allow estates to continue in these socially detrimental production schemes while passing off their increased infrastructural burdens onto the state (Follett-Smith 1954, 9).

Relief schemes allowed the government to kill two birds with one stone. The elevated levels of unemployment suppressed wages to the extent that a large number of workers could be hired on for relatively little money. These workers could then be

\footnotetext{
${ }^{31}$ Letter to Lord Passfield, $4^{\text {th }}$ July 1930 , CO $111 / 688 / 8$, The National Archives, UK ${ }^{32}$ Report of the Economic Investigation Committee, CO 111/688/8, The National Archives, UK

${ }^{33}$ Ibid.
} 
contracted to build and maintain flood control infrastructure for much less than would otherwise have been possible in normal economic conditions or if the workers were in a position to demand higher wages, addressing the financial shortcomings of the new flood defense policies. This combination of un- and underemployment as well as the state intervention into flood control infrastructure effectively provided the estates with a new source of free labor. In the case of the loan provided by Sandbach Parker, estates were also able to directly profit off of the situation.

Despite these efforts, the East Coast Demerara region, home to many of the African villages, saw severe flooding in January 1934, with several villages - including Plaisance - and remote sugar and rice estates being inundated almost entirely while the large estates that most benefitted from the free labor provided by the Department of Public Works were left relatively unscathed. While this could be coincidental, considering the geography of the flood (inundating the entirety of the east coast for a variety of reasons, mostly infrastructural failure) it seems unlikely.

\section{Conclusion: Sugar, Floods, and Reserve Armies of Labor}

The clear result of these floods and the colonial responses to them is the reincorporation of villagers and other colonized people into the plantation system in the wake of any failure of the flood control system. Coastal flooding, rather than serving as a severe threat to the colonial political economy, ultimately benefited the sugar industry by providing them with a pool of cheap labor who lack other options for the very means of their survival. Flood control technologies and the legal requirements surrounding them could be manipulated in such a way as to turn flood control efforts into part of a larger racial 
politics of social control through the precarity - either threatened or experienced - of the Afro-Guyanese population. In this way and despite their apparent autonomy from the plantation system, villagers fill the role of what Karl Marx (1887) refers to as a "reserve army of labor." In times of economic crisis, villagers served as "a mass of human material always ready for exploitation" and able to be mobilized for the accumulation of capital in times of crisis, in particular times of flooding (Marx 1887: 784). While typical Marxian analysis of surplus labor considers primarily the unemployed, which coastal villagers were often not, the broader operations of power within the colonial environment meant that, effectively, the population of surplus laborers in British Guiana were treated as such and the economic precarity introduced by the threat or experience of coastal flooding rendered this treatment visible. The portions of their lives outside of the plantation system, rather than posing a threat to the plantocracy or even providing them with other means by which they could survive the environmental and economic shocks of colonialism served its purposes particularly well. As floods threatened the coast, either in the imminent form of failed drainage and sea defenses or in the direct form of a flood itself, the conditions were always in such a way that the threat was not only more immediate to but also directed toward the villages, be they African or Indian in racial composition. The breakdown of village life, including the economic autonomy that came with it, provided the sugar industry with labor at rates well below those that which could otherwise be paid. This arrangement was structured by the legal system and its imposition of equal treatment of the villages and estates under the law, an arrangement lobbied for by sugar interests. The end result is a sort of resilience for the sugar plantations (and thus the economic system which propped up colonialism) at the expense of resilience for 
village populations. The potential of a life free from unstable and capitalistic plantation economy was denied to those who sought it. Instead, the burdens of broader economy were placed on their tables through their incorporation into the primary system they shared: infrastructure. What was once the promise of freedom from the fluctuations of the sugar market, the promise of a self-reliant economy that could handle the shocks of the global economy through its distance, became a promise of continued precarity as water infrastructure was used to reincorporate them back into plantation life.

This is in line with what Percy Hintzen (2017) has argued for occurring in peripheral and semi-peripheral capitalist systems more broadly. Specifically, he argues that "the social forces of the state and national authority were also deployed to control, discipline, and regulate those located outside of the space of capitalist formation in order to ensure they did not disrupt the process of capital accumulation. The latter also became organized into 'segments' of 'surplus labor' to be made available for capitalist production when needed and for conscription into the service of national authorities, even while remaining outside of the space of capitalist accumulation" (Hintzen 2017: 4). In Guyana, as well as in similar colonial economies, this process was racialized, with Afro-Guyanese typically serving the role of surplus laborers due to contractual agreements between estates and Indo-Guyanese laborers that were worked out in 1921 (Sugar Producers Association 1954). Though not entirely outside of the plantation system (see Rodney 1981b; Sugar Producers Association 1954), African villages were ideal spaces to serve as banks for surplus labor to be drawn upon when the financial situation of the sugar industry was under threat. The threat of flooding and its ever-changing legal requirements and repercussions ensured that this was the case, allowing floods and the flood 
management infrastructure meant to mitigate against them to become key tools in the colonial governance of the colonies.

Importantly, this also demonstrates the ways in which the development of flood control infrastructure was so heavily entwined with the broader racial politics of the colony. When and to what extent flood control projects were legislated, funded, and to whom they benefitted were structured both directly and indirectly by the relationship between Afro-Guyanese laborers and the plantation economy in the post-slavery period. While flood control projects certainly pre-date the end of slavery, the new constitution of social life on the coast created new anxieties and possibilities for flood control infrastructure and in turn extended the operations of power (both potential and realized) through broader systems of infrastructure, both those built at the behest of colonizers and those natural systems which are themselves part of that infrastructure (cf. Carse 2014). Brian Moore $(1987,97)$ has argued that "colonial authoritarianism was not born in bad drainage; rather the latter merely served as an excuse for resorting to the former." However, as I have shown in this chapter it was drainage itself that was a means by which this colonial authoritarianism was produced and enacted. Rather than a simple excuse, it was in itself a form of authoritarian governance. But this did not happen on its own. At the same time that new legal and financial structures were affecting the ability of Afro-Guyanese to prosper in their villages, workers on the sugar estates were facing increasingly harsh conditions and suppressed wages resulting in strikes, riots, and other forms of labor action. To mediate these emergent challenges to colonial authority, a rice industry was developing meant to alleviate other financial burdens facing the colonial 
government and, in turn, establishing an entirely different form of flood control that also fell along racial lines. This is the topic of the next chapter. 


\section{CHAPTER 3 - RICE, RACE, AND EMPOLDERMENT}

"Guyana's Rice Industry provides a livelihood for more people, directly and inirectly, than any other industry in the country. In one way or another, almost one quarter of a million of our people earn employment through the rice industry and forty-five thousand families work in our rice farms."

- Ptolemy Reid, Minister of Finance, June 7, 1968 (Quoted in Richardson 1970)

\section{Introduction}

The turn of the twentieth century saw rapid population growth in Guyana. Improved healthcare was extending life expectancies while the end of indentureship led to a rising and newly independent East Indian populace. With a sugar industry at times incapable of and at times averse to employing all the workers available in and around the capital city and a growing population, unemployment was becoming a significant issue that was increasingly complicated by the country's historical ties to coastal agriculture and a general unwillingness (and a historically constituted inability) to diversify (see Khemraj 2015; Ramraj 2001).

At the same time, the end of indenture contracts resulted in the growth of a second emergent laboring population with historical ties to the sugar industry. Early indications show that the inter-ethnic relationships between Afro-Guyanese and the formerly indentured populations (including not only Indo-Guyanese but also Portuguese and Chinese) were amicable at times but that conflict emerged as a result of the strike- 
breaking activities, producing ethnic boundaries based primarily on the social solidarity found (and encouraged) within ethnic groups (Bartels 1977). These conflicts developed (albeit unevenly) through a series of riots between these laboring groups beginning in the 1840s when Portuguese indentures were given preferential treatment over villages in terms of access to small market spaces (Moore 1975; Wagner 1977). The conflict was, however, relatively short-lived and the working classes would largely return to their general apathy until re-united by a common anti-colonial sentiment (Moore 1987, 193). In 1905 that unified sentiment began fomenting in earnest around what would come to be known as the Ruimveldt Riots.

In December of 1905, stevedores, porters, and other Afro-Guyanese workers remaining in the sugar industry went on strike demanding higher wages. Supported by the largely-immigrant middle classes of the colony as well as the lumpen and village populations, the workers demonstrated on the streets of Georgetown in increasingly militant actions against the colonial government while, simultaneously, they agitated on the plantations against East Indian scabbing which had been used to break previous strikes (Rodney 1981). Though never involved directly in the strikes, Indian plantation laborers (both indentured and "free") refused to fill the positions of the striking workers and helping to make the strike more effective. In return, the striking workers made demands on behalf of all workers rates, arguing that wages were not meeting the rising costs of living in the colony and that the current economic depression was resulting in less hours paid pro rata. In Walter Rodney's (1981) analysis, this multi-class, multiethnic solidarity was a turning point in the history of Guyana's working people, one which would bring about a new threat to colonialism, the only apparent and existing 
solution to which was the exploitation of racial and ethnic differences (Moore 1987). According to Moore (1987), this exploitation was dangerous and new ways to "divide and rule" the colonial populations were necessary.

In chapter 2, I discussed the ways in which infrastructure was used to quell surging unemployment rates while reincorporating Afro-Guyanese back into the plantation economy after the development of the village movement and the historical strikes resulting from decreasing wages. This was a stop gap measure that could satisfy the sugar industry, but which did not resolve the underlying socioeconomic issues that were causing unemployment in the first place: a growing population and a dying market for cane sugar in general and Demerara sugar in particular. Widespread political and economic precarity resulting from this industrial failure combined with colonial racial characterizations that preferred 'industrious' Indians to 'lazy' Africans is the often-cited reason that the unity of working people could not last. Dennis Bartels (1977) argues in an article representative of this Marxian analysis, for example, that the relatively positive racial stereotypes attributed to Indo-Guyanese resulted in favorable policy-making thus furthering the material divide between the two populations. Brian Moore (1987) has argued that economic specialization created space between the major ethnic groups but still provided lines along which they could built interdependence and thus cross-racial solidarity. While I do not disagree with either Bartels' or Moore's analyses, I want to argue that they account for only part of the story. To address larger problems within the colony and the emergent threat to the colonial project itself being produced through the alienation of the working populations, the Colonial Office, Colonial Development and Welfare, and British Guiana government undertook large-scale drainage projects to bring 
tens of thousands of acres of regularly flooded lands under cultivation and to - through the establishment of small villages adjacent to the land - encourage population growth along the stretch of the coast. If appropriately racialized, this project would provide geographic and economic independence among these communities, along the colonial government to treat each group as distinct and thus limit the impacts of things like strikes to the larger colonial project.

In this chapter, I examine the social history of this land development, looking in particular at the ways in which it produced new racial geographies along the coast. Drawing on archival research conducted at the National Archives in London, UK between 2015 and 2017 and interviews and fieldwork conducted in Den Amstel, West Coast Demerara (an African village adjacent to the Boeraserie Scheme), I argue that these projects were in part an attempt to relieve racial tensions and anti-colonial sentiment in the country's post-union movement period and played a similar role through UK intervention in the postcolonial period. The result has been the increased geographical, social, and economic distance between large portions of the population resulting in an overall in a lack of resilience due to social fragmentation. I also argue that, just as previous attempts to reincorporate Afro-Guyanese into the sugar industry served not only as a means of maintaining white supremacy but also (and more broadly speaking) to prop up a dying colonialism, the development of a rice industry did the same. Not only did it provide the ethnic difference necessary to end or avoid anticolonial revolts, it also provided new sources of income to make up for the profits lost by the shrinking of the sugar industry. 
Many of the lands used for these new land settlement projects were once sugar estates, abandoned either shortly after the abolition of slavery in 1834 or during later depressions when the rising costs of upkeep and lower sugar prices reduced the profitability of the smaller estates, particularly those that did not have any legislative sway $^{34}$. Changing land use from one commodity to another was not as simple as tilling and replanting. In discussing the requirements to shift from fields designed and laid out for sugar production to the production of rice, an Afro-Guyanese civil engineer who worked on several drainage and irrigation projects from the 1970s to the 2000s explained to me that it was not as simple as clearing the brush and changing the amount of water flowing in. Rather, cane fields are built with each row of cane on a small hill to facilitate rapid drainage during heavy storms while rice fields are ideally flat or gently sloping toward a canal (see Plate 4 and Plate 5). In order for a successful conversion from one use to the other, the fields themselves need to be levelled at significant expense. In the early years of rice production, former estate lands were purchased and then sublet to a number of tenants who were individually responsible for making the necessary modifications to the land or were made up of small disused sections of larger sugar estates and managed by the predominantly East Indian staff working in the area (Rice Farmers Committee 1953). The settlement schemes, requiring thousands and thousands of acres of land to be brought into productions required significant expense. With the few remaining large estates and apparently no colonial capitalists willing to undertake these expenses, the

${ }^{34}$ For a detailed discussion of the history of sugar prices and their impact on Guyana's economy, see DaCosta 2007. 
burden of large scale conversion was laid at feet of the Colonial Office and the British Guiana Government.

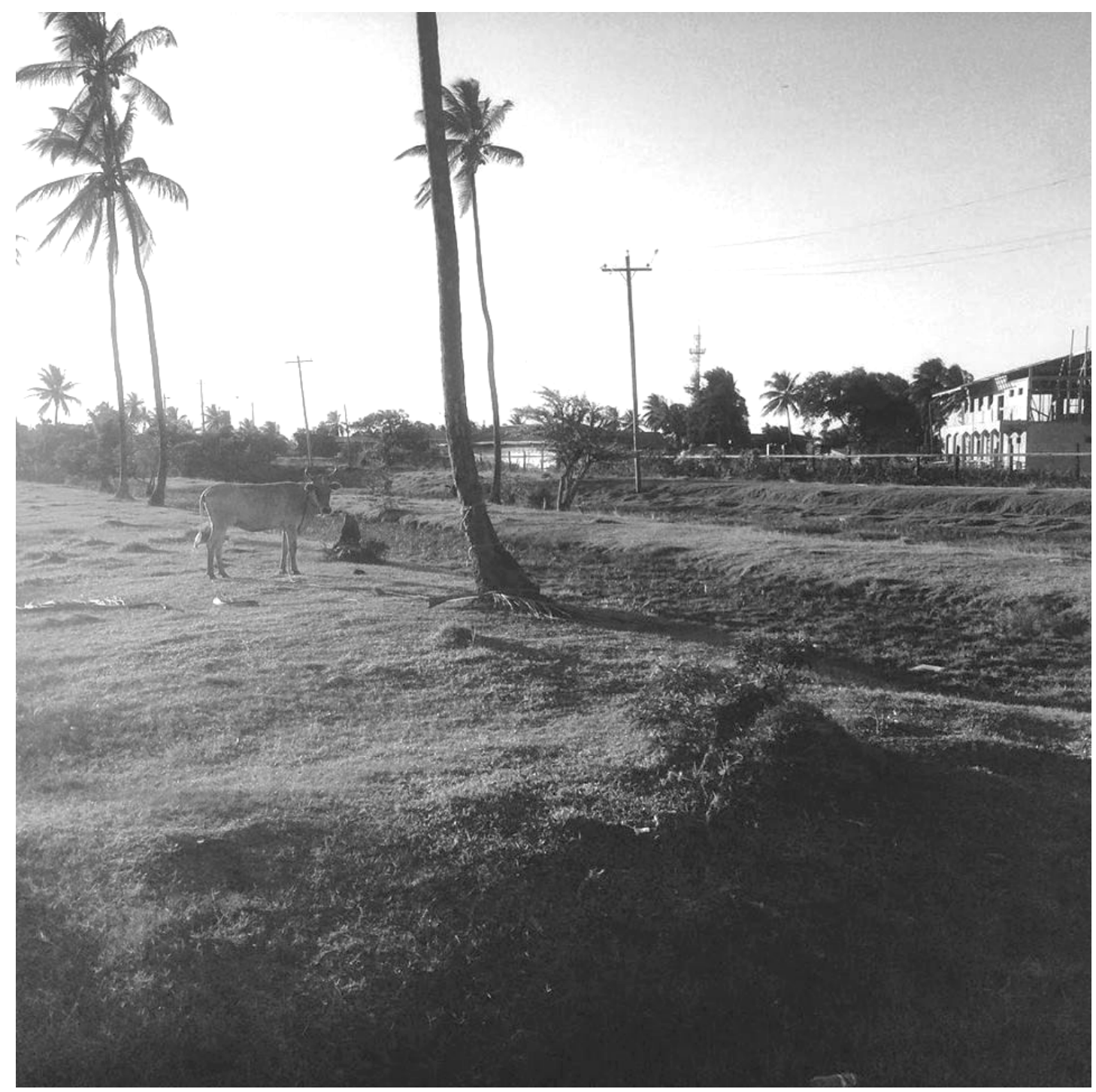

Plate 4 - Former cane fields now used for grazing in Den Amstel, Guyana, adjacent to the Boeraserie Scheme. Note the ridges used to wash water away from the cane and toward canals. (Photo by Author November 2017). 


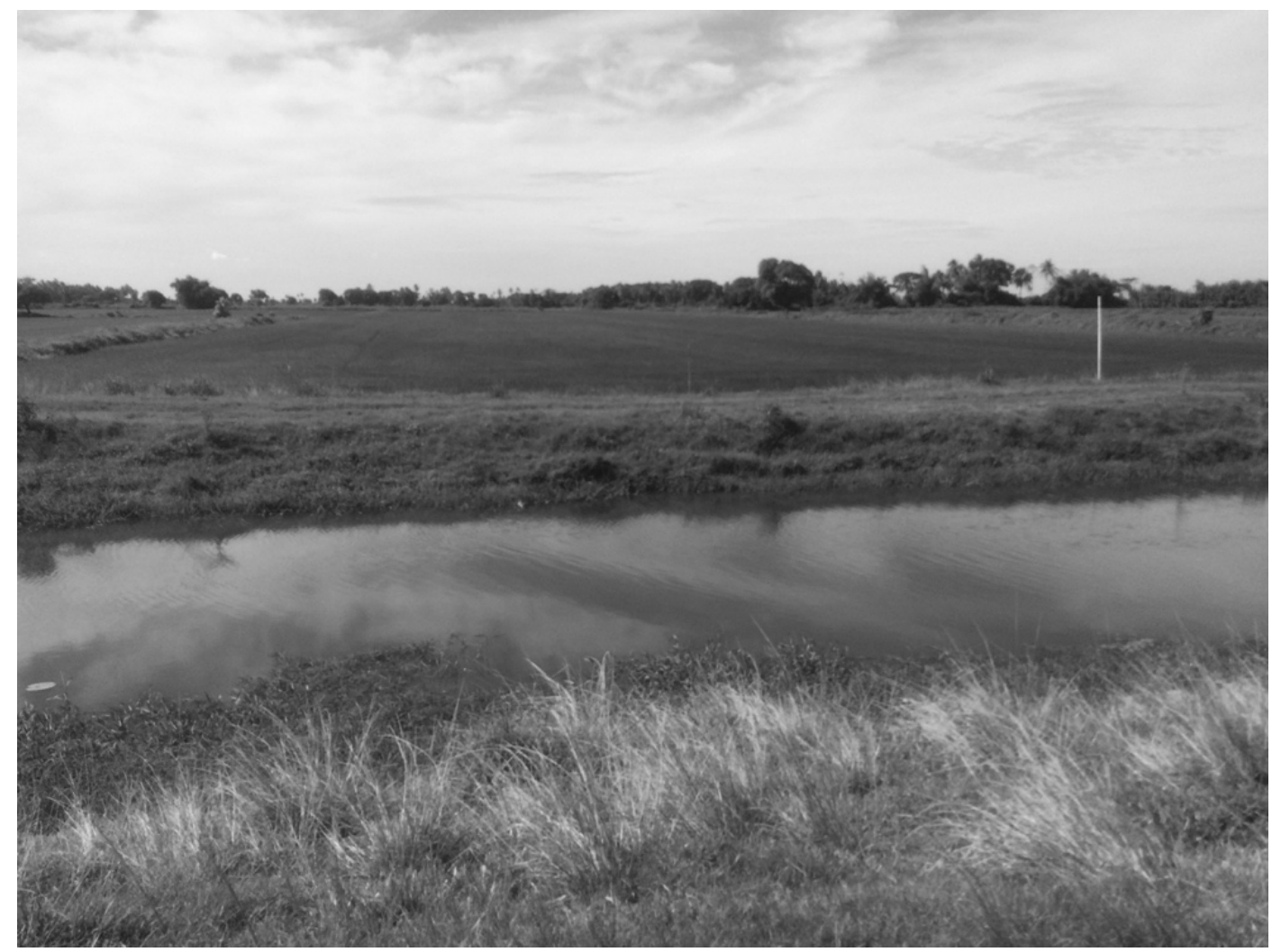

Plate 5 - Former cane fields flattened and converted for rice production in the Tapakuma scheme, Pomeroon-Supenaam, Guyana. (Photo by author, June 2015).

The two-fold nature of this venture (repurpose sugar fields for rice production and create a village system for the peasant farmers who would work them) resulted in a number of civil and environmental engineering problems which needed to be resolved, the most significant of which was the question of how to manage water. How could engineers modify and expand the existing systems of canals and dams to ensure there was enough water for agricultural production, particularly water-heavy crops such as rice for which colonizers had identified a local (circum-Caribbean) market, while also ensuring that the villages surrounding the fields would not become inundated should flooding occur? From the beginning, these schemes were envisioned as small-holder projects that 
may or may not see mechanized production based on the needs, desires, and economic ability of the farmers. Thus, they also needed to ensure that villages were close enough to the fields that they would not be neglected in favor of the smaller family plots used primarily for subsistence. How did engineers and colonial officers navigate this terrain? How did the developing racial politics in the country and the growing anticolonial movement affect the ways in which projects were planned? In what ways did this set the stage for future infrastructure maintenance in the postcolonial period?

I answer these questions through an examination of three rice development schemes: Boeraserie (40,403ha), Black Bush Polder (12,545ha), and Tapakuma $(10,926 \mathrm{ha})$ (see Figure 3). These schemes span much of Guyana's coast, covering portions of the West Coast Demerara, Essequibo, and Berbice regions respectively. They also each presented their own challenges and produced their own racial spatializations of labor. I begin this chapter with an overview of the empolderment process that made the realization of these schemes possible, examining the ways in which empolderment has been used to shape political and economic regimes beyond Guyana. Next, I use this analysis to re-introduce the relationship between race, food, and agriculture developed in the introduction as well as chapter 2 , looking specifically at the processes by which food production becomes a means for both repressing and mobilizing colonized people and linking them to larger political and economic conditions not because they serve particular colonial economic needs but also for the ways in which such linkages can be used to solve a variety of issues which serve to threaten colonialism. Finally, I provide a general overview of Guyana's history of indentureship and the racial politics of land settlement involved at the end of the indentureship period before looking specifically at the above 
named empolderment projects. I conclude with a brief reflection on the ways in which these systems continue to shape life in Guyana, especially through new processes of urban movement from the country's village extremes and the continued minimization of the sugar industry by the current government.

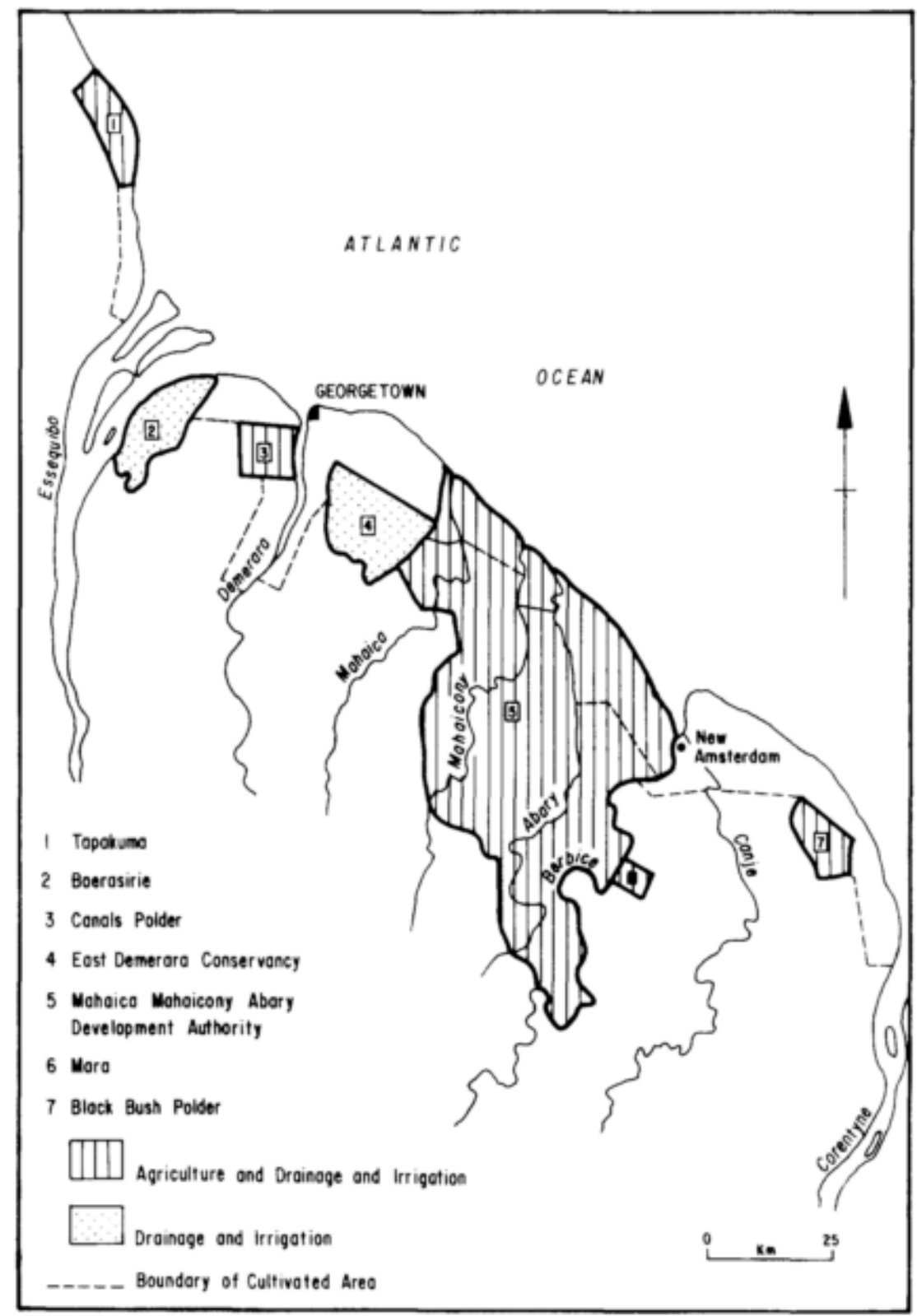

Figure 3 - Map showing the location of major drainage and irrigation projects in British Guiana. Source: Daniel 1988. 


\section{The Critical Physical Geographies of Empolderment}

In the first chapter I outlined the broader physical geography and historical geology of the coast. Chapter 2 I briefly reviewed the politics embedded within the drainage, irrigation, and defense artefacts associated with coastal drainage, noting how they stake long-term claims for particular capitalist formations and political desires. This is true for polders as well, but to a different extent and inclusive of different reasons. Empolderment is a sort of infrastructural master project, encompassing a wide variety of other infrastructural commitments which must be maintained as a unit to ensure the empoldered lands are not inundated. This differs from other drainage schemes primarily in the scale in which it occurs. While it was not uncommon for local landholders to cut canals, build dams, and drain lands for agricultural production (as in Chapter 2), these projects were traditionally worked, maintained, and to some degree legislated at a much more local scale than empolderment projects which have geographically larger (and in the context of British Guiana, colonial) significance. To an extent, the centralization of drainage authority in the mid- $20^{\text {th }}$ century means that all of Guyana's coast has been empoldered in one way or another, but this chapter examines specific empolderment schemes, whereby an area of land is deemed unsuitable for cultivation, is (re-)empoldered through extensive construction of dams and canals, and is turned into an economically (and in this case at least, socially) productive space. In these projects, empolderment served as a means of manipulating the physical environment in order to expand the colonial capitalist economy into new geographies. They corresponded with land settlement projects meant to redistribute the population along the coast and provide workers, primarily of East Indian descent, for the new schemes (see Greenidge 2001). As 
mentioned in Chapter 1, the field of critical physical geography is particularly well suited for understanding such processes.

Empolderment is perhaps one of the world's oldest large-scale environmental engineering processes. At least as far back as the middle ages, Dutch citizens were building "encircling dams" and complex systems of canals, dykes, and other infrastructural artefacts to secure, claim, and reclaim land from the sea (TeBrake 2002; Hughes 2009). This was necessary because, like Guyana (see Chapter 1 - The Precolonial and Early Colonial History of Coastal Settlement), The Netherlands had large areas of peat soil. Seeking additional land for agricultural production and settlement, people drained these peaty areas causing the density of the soil to increase, the volume to decrease, and the land to subside and eventually flood, either through new spaces for meandering for one of the country's rivers or for flooding from the sea (Hughes 2009). By enclosing the land prior to draining it, the Dutch were able to minimize the negative environmental impacts of this subsidence. The large-scale engineering efforts of the Dutch have given rise to a popular refrain in the literature on Dutch water management: "God made the world, but the Dutch made Holland" (see Hughes 2009). But if the Dutch "made Holland," they also created the conditions which made these projects necessary as they sought out new lands for capital accumulation. This was true also in Guyana, where colonial records show that early empolderment projects (some of which were built with advice from Dutch engineers but were not products of the Dutch colonial period ${ }^{35}$ )

${ }^{35}$ Minutes, CO111/724/3, The National Archives, UK. 
resulted in increased flooding in surrounding areas, simultaneously creating new land for cultivation while inundating previously cultivated land. In a letter to a member of parliament, one colonial engineer described the extent of the problem, stating "small portions of land on the flood plains have in fact been empoldered, but this while securing the safety of those particularly areas, has only accentuated the problem [of flooding] outside them. There is obviously a limit to the effectiveness of such piecemeal empoldering since each new empolder simply diverts the flood water with increasing force elsewhere and so results in a situation where protection of land becomes progressively more expensive."36

Because polders work by redirecting natural flows of waters around enclosed areas they serve two key purposes besides land reclamation. First, empoldered land must be continuously drained to ensure it does not simply become a large lake in the event of pluvial flooding. This is done by pumping or otherwise draining water through canals into nearby rivers or the ocean. In the Netherlands, windmill-driven pumps were used while in Guyana a combination of gravity drainage and, later, mechanical pumps were used to move this water. Second, during times of drought, the gates accompanying these pumps can be used to flood the canals providing a source of fresh water for continued cultivation (Schuetze and Chelleri 2011). Though useful for the development of agriculture, this canalization changes watershed dynamics in a way that carries with it a number of negative secondary effects which must be mitigated by future engineering

${ }^{36}$ Letter from John Profumo to Dr. J. Dickson Mabon, MP. 17 $7^{\text {th }}$ September 1957. CO1031/2425, The National Archives, UK 
works. In the case of the Netherlands, this has resulted in the threat of salinization of both to the aquifers and to the canals, due in part to an increase in both the frequency and intensity of droughts (Schuetze and Chelleri 2011; see also Bouwer, Bubeck, and Aerts 2010). As droughts occur and less freshwater runs through the river system, there is less freshwater to recharge aquifers and less pressure holding back salt water at the estuaries. This results in salt water intrusion, whereby salt water enters the freshwater aquifer system (see Essink 2001) and allows salt water to enter canals when gates are opened to flood them with irrigation water (Schuetze and Chelleri 2011).

The control of water, and especially seawater, also has cultural implications. Stefan Helmreich (2011) calls water a "theory machine," an object which, through its widespread significance serves as a means of stimulating theoretical insights (see also Galison 2003). This is reflected in the work of Timothy Mitchell, Sara Pritchard, Jessica Barnes, and others that have been reviewed throughout this dissertation but Helmreich's understanding of water as a genesis for theoretical-cultural insights in itself is important here because it also lets us think theoretically about attempts to control it and what this means for those involved. From its origins, empolderment has been less a project of protecting humans from natural hazards as a means of protecting people and property from a combination of geophysical hazards created in the name the accumulation of capital. As recently as the mid- $20^{\text {th }}$ century, the government of The Netherlands has developed polders to reclaim land from the sea in order to expand areas for agricultural production and population settlement (van Schoubroeck 2010). In this way, it makes sense that British Guiana's authorities sought to use empolderment as a means for solving its land settlement problems. However, despite its political economic origins, widespread 
adaptation in colonial and postcolonial countries, and unlike other infrastructural projects, empolderment has been largely understudied. The lack of recent critical analysis on large-scale infrastructure projects is somewhat surprising given a return to infrastructure in water management after and in combination with the ecological turn (see Crow-Miller, Webber, and Molle 2017). There have been a handful of critical studies of drainage and irrigation in Guyana that have looked at empolderment schemes, but often indirectly (i.e. as isolated analysis of village life) or ignoring the political, economic, and cultural complexities shaped by and embedded within these systems, focusing instead on the purely technical measures of their functioning (e.g. Daniel 1988; Danns 1997; Farley 1954; Greenidge 2001; Lakhan 1994; Nasseer 1978; Ramraj 2001; Richardson 1972; Richardson 1973; Strachan 1980; Veramallay 1976; Vining 1977).

Expanding empolderment to include other practices of land reclamation can also be fruitful for understanding the ways in which such projects can be used not only for the purposes of capitalist accumulation but also a means of social control, extending state power into a variety of areas often overlooked in more traditional political economic analyses. Jessica Barnes (2017), for example, highlights the ways in which the maintenance of irrigation infrastructure used to create arable land along the Nile has also created sets of social relationships that in turn shape and maintain the regional material and social order. Similarly, Rae Choi (2014) shows how land reclamation projects in South Korea's tidal flats - which were discursively defended as modernization projects actually contributed to regional underdevelopment by alienating rural workers from the economic growth being experienced in more urbanized areas. These insights allow us to consider the ways in which projects in Guyana may have impacted social organization, 
relationships between rural workers in reclaimed land and the larger economy, and, because these projects were primarily land settlement for Indian-descended people, the racial politics of these divisions.

Polders, Politics, and Agriculture

A common thread between empolderment projects in Guyana and other largescale infrastructure projects is their seemingly incessant focus on monocrop agricultural production. As noted above, both empolderment and other processes of land reclamation have historically been undertaken with the primary goal of increasing the availability of foodstuffs in a given region, whether to feed local populations or for export. In Guyana, this was largely the case for rice production. As mentioned previously, a wide variety of crops were grown in the colonies that now make up Guyana up until British colonization, but even then, these crops were grown as export commodities to be sold to metropolitan consumers. Subsistence crop production was largely ancillary to growing crops for foreign markets. Rice production, existing as early in 1753, was seen to be a potential boon for planters starting to establish themselves under Dutch colonial rule (Richardson 1970). Early Dutch governor Storm Van's Gravesande noted the potential for rice under this movement, stating "It is a pleasure to see how cheerful, zealous and industrious the new-comers are. In addition to sugar plantations, several will be laid out with coffee, and the arrivals from Carolina will devote themselves to the cultivation of rice. On Mr. La Villette's plantation I have seen rice standing neglected and have no doubt that it will be a great success and yield good profits to the planters" (Harris and de Villiers 1911, 293, quoted in Richardson 1970, 56). Under British supervision, this production consolidated 
around the sugar industry owing at least in part to soil exhaustion and more generalized land degradation in their other Caribbean colonies (Carrington 2002). Under this system, drainage and irrigation infrastructure also united around sugar production and the estate system at the expense of small holder production.

In the 1860s, two East Indian-descended people used oxen to cultivate rice on the foreshore of the Edinburgh sugar estate, but as late as the 1890s rice was still only produced at a relatively small scale, with only an average of 7,490 acres under cultivation between 1894 and 1898 and the first rice for export not being produced until 1903 (Rice Farmers Committee 1953; Richardson 1970). The sugar depression of the 1920s and 30s saw a new colonial focus on rice production and with it the amount of land under rice cultivation would increase dramatically and rapidly. By 1930 enough rice was being produced that the Ministry of Agriculture established full-time rice grading offices and by 1952 production reached over 134,000 acres in active cultivation (Rice Farmers Committee 1953; Richardson 1970; see Figure 4). This rapid increase in rice production was due in part to the leasing of crown lands for rice production at relatively low rates across the colony (previously, rice production was done on small parcels leased from estates with most rice producers earning the bulk of their income in the sugar industry, see Richardson 1970, 58.) Without any large-scale scheme, however, this production was ad hoc and prone to rapid declines in production as a result of flooding (these declines are clear in Figure 4). This production also fell outside of the larger system of drainage and irrigation at times, owing to regulatory changes focused on the sugar industry discussed in Chapter 2. Instead, outside of the larger land settlement schemes that are the primary subject of this chapter, infrastructural responsibilities fell variously to tenant, landlord, 
local authority, and Drainage and Irrigation Board depending on both the location of the field and extent (and expenses) of the work (Rice Farmers Committee 1953). For their efforts, rice farmers had relatively secure land tenure rights and low rents under the Defence (Restriction of Eviction of Rice Farmers) Regulations first released in 1942 and the Rice Farmers (Security of Tenure) Ordinance of 1945.

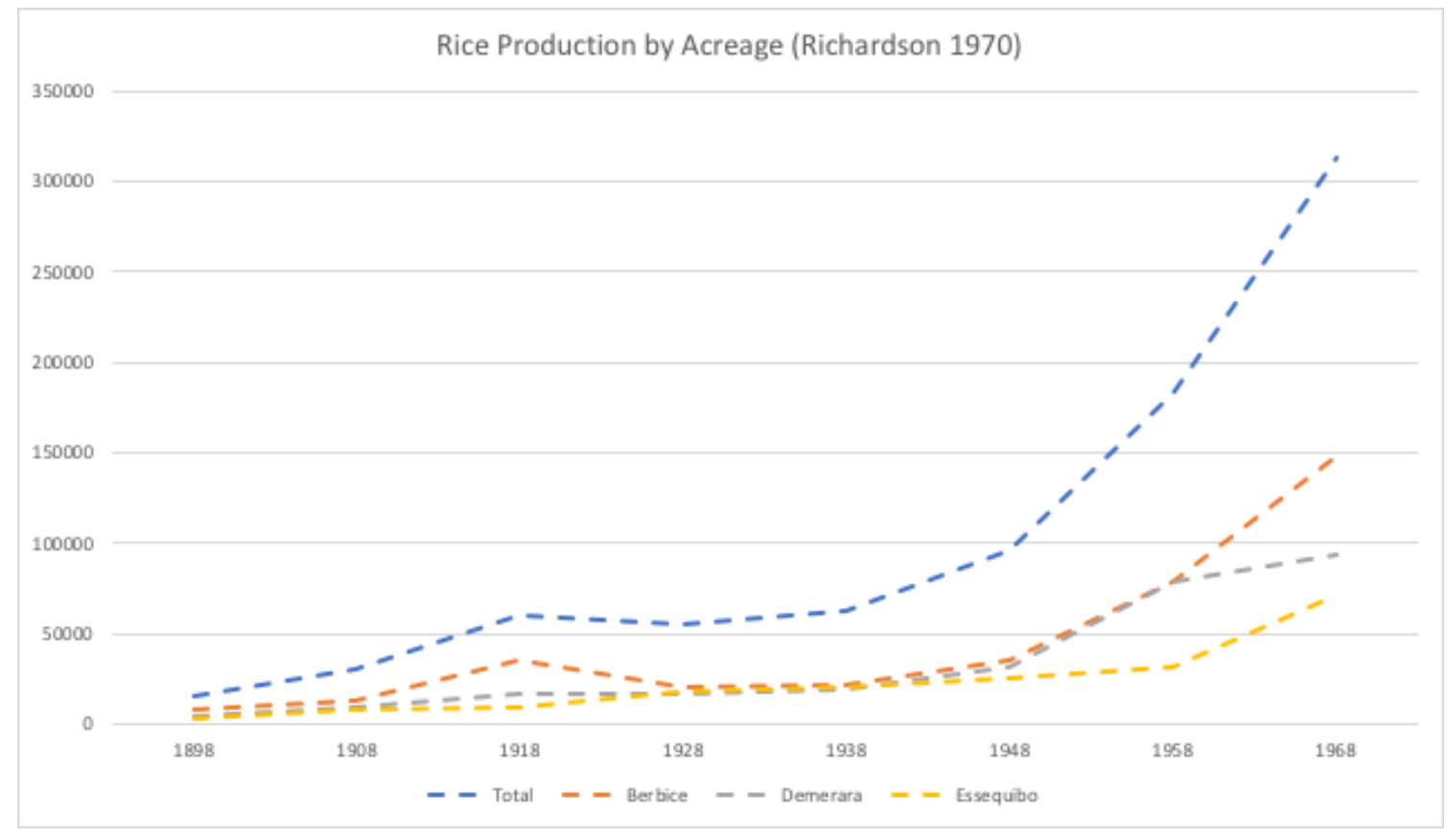

Figure 4 -Rice Production by Acreage 1898-1968. Adapted from Richardson, 1970

Outside of the structures of colonialism, rice was produced by Africans who had escaped the shackles of slavery and setup villages on the fringes of the colonies (Farley 1954). In the early years of British colonization, this was a major point of both interest and derision for colonial administrators. Rawle Farley (1954) notes how then-Acting Governor of Berbice Samuel Dalrymple timed expeditions against these villages to 
correspond with the rice production cycle to ensure maximum damage to African fields and thus their ability to survive. When accounting for this destruction, Dalrymple estimated that enough rice had been produced - excluding other ground provisions - to feed as many as 700 people for a year ${ }^{37}$. That such widespread agricultural production occurred under the autonomous self-management of escaped Africans is not surprising. Judith Carney (2001) has shown how people from across the Upper Guinea Coast have a long history of rice production, predating European colonization of the Americas (for a contextualization of this production into the broader western African economy see Rodney 1970). Her work demonstrates not only that African people had a large rice producing culture in Africa, but that they brought this cultural knowledge with them when they were forced to work in American fields. As shown in the above quote from Storm Van's Gravesande, rice may have first been introduced to the Guianas by way of the Carolina rice industry that Carney (2001) so beautifully historicizes (Richardson 1970). An unfortunate consequence of the wanton colonial destruction of these African fields is the lack of knowledge about the ways in which these "maroon" villages organized their social and material worlds and with them alternatives to the colonial order of things.

Unlike sugar, which was produced primarily as an export product for the American and later European markets (for a detailed analysis of this see Carrington 2002), rice had a significant local and regional market which produced new challenges

${ }^{37}$ CO 111/78 Extract from the Minutes of the Court of Policy of Demerara and Essequibo. 
related to the organizational needs of the system, but it also solved two problems for the colonial government. First, the large amount of land under cultivation for sugar meant that most of the actual edible produce was produced on a small scale. Many plots were subsistence-focused and, as demonstrated in Chapter 2, were often disrupted by flooding. This meant that most of the food consumed in British Guiana and other British Caribbean territories was imported from other colonial areas, making the country reliant on extant British trade agreements and successful agricultural yields in other, more distant colonies such as those in East and Southeast Asia. Producing rice in land rich British Guiana allowed for a commodity that could be processed and distributed locally and regionally a point of importance when international transport was limited due to the First and Second World Wars. Rice, still a cash crop, was seen as vital to the success of these schemes. As an anonymous commentator noted in a comment on the Report of the Land Settlement Committee in July of 1939, "the essential point of a land settlement scheme is the cash crops to be grown, as settlers cannot succeed on a basis of subsistence farming alone $^{38} . "$ The goal then was not to create a system in which settlers could work in their own self-interest but instead to perpetuate what increasingly appeared to be a dying colonial capitalism. By the time land settlement was in full effect, rice had become a highly desirable crop in the Caribbean. With the outbreak of the First World War, rice supplies from the colonial East Indies had been cut off, leaving stores of the staple crop low throughout the western hemisphere (Naseer 1978). Seeing the opportunity for quick

38 "British Guiana: Comments on the Report of the Land Settlement Committee," CO111/766/5, The National Archives, UK 
cash on the export market, estate managers and peasant farmers, with the support of the Colonial Office, began establishing rice fields. Though lulled to near extermination in the interwar period, the Japanese occupation of rice producing territories across Asia gave new life to Guyana's industry.

Though spurred on first by planters and later by the economic politics of total war, rice production was also important in the postwar political economy. It was, significantly, a major concern for decolonization advocate and politician Cheddi Jagan. In 1961, after a large rice order from Fidel Castro's Cuba, Jagan - then acting as the Minister of Trade and Industry in the semi-autonomous government - sought to reclaim even more lands and expand the industry further, stating "We can all go forward confidently in our drainage and irrigation schemes, land settlements, and in bringing more and more land into [rice] cultivation" (quoted in Richardson 1970, 61). With Burnham's election in 1964, however, the Cuban market disappeared and with it a large source of income. The loss of the Cuban market combined with the fact that Jagan had been paying out greater prices to rice farmers than he was receiving from rice buyers in order to advance his political career left the rice industry bankrupt, compounding the existing environmental and political challenges facing East Indian communities dependent on rice production (Richardson 1970).

Second, and perhaps more importantly for the colonial project as a whole, rice production provided a means for offsetting the costs associated with the end of indentureship. By 1939 the question of land settlement had become a contentious point in British Guiana. Facing the imminent threat of a second world war and still recovering from a decade long economic depression, the British sought to pre-emptively reduce 
costs throughout their empire. One way to do this was to offer land to recently released indentures in exchange for the return passage they had been promised with the grants of land being "a charge on the Immigration Fund to limit the liability of the Fund for the repatriation of the expenses of immigrants." 39 Between 1838 and 1917 a nearly 239,000 indentured laborers entered the colony to work in the sugar fields in place of black laborers who had since refused or had been denied the right (see Chapter 2 - "A Mild Despotism of Sugar": Race, Labor, and Water Management), the majority of whom were from British colonies in South Asia (Naseer 1978; Lakhan 1994). From this group only around 75,000 returned (Naseer 1978). The remaining population remained to work in the sugar fields as free laborers or settled in a variety of small villages near the centers of sugar production until economic crises in the sugar industry pushed them out, leaving them with nowhere to go without the assistance of government settlement schemes. These new settlers would be granted land on an 11-year lease with the maintenance costs for the first year being spread over the remaining 10, in the case of those who exchanged their return passage for land all costs would be waived for the lease period. Though technically available to anyone in the colony, there existed within the Colonial Office and in the Government of British Guiana a "relative preference of negro and East Indian cultivators for cane and fruit farming and for rice cultivation respectively. ${ }^{40}$ " In terms of

\footnotetext{
${ }^{39}$ Minute of 18/3/1939, CO111/766/5, The National Archives, UK ${ }^{40}$ Ibid.
}

By the late 1970s, Indo-Guyanese accounted for more than 90 percent of coastal rice producers (see Naseer 1978). 
both the agreement for settlement (with lease costs being waived entirely for East Indian settlers willing to exchange their return passage) and the fact that much of the settled land was to be part of rice producing schemes rather than those focusing on sugar, East Indian populations saw clear advantages over their African-descended neighbors. The focus on sugar was also disregarded at one point because "sugar can stand the capital cost of drainage and irrigation works in addition to the cost of upkeep, and it is assumed as axiomatic that rice cannot." ${ }^{41}$ It should also be made clear that East Indians were not universally treated better than Afro-Guyanese. At the same time that settlement schemes were being discussed, East Indian villages were being regularly flooded by the drainage of excess waters from the East Demerara Water Conservancy. One commentator even suggested to the Governor of the colony that a solution to this problem could be to relocate those affected to rice lands in one of the new settlement schemes rather than actually finding an engineering solution. As he argued, "the taking of such measures would be in accordance with the policy which has been adopted, as the result of outbreak of war, of increasing the production of local food-stuffs and in this connection I note that rice which it is especially desired to encourage in British Guiana to meet the needs of the West Indian market, is one of the commodities grown in the areas concerned." ${ }^{42}$

${ }^{41}$ Minute of 8/11/1940, CO111/766/5, The National Archives, UK. ${ }^{42}$ Minute 1A of 29/8/1939, CO111/763/3, The National Archives, UK. 
Boeraserie and Black Bush Polder: Rice, Drainage, and Sea Defense

As shown above, experiences with rice production in the inter- and post-war periods highlighted the general inefficiency of current drainage and irrigation schemes to function within a rice-based economy as well as a general lack of coordinated planning on the part of agricultural producers and the state more generally (see also Lakhan 1994). The first attempts to create from scratch a new scheme of land settlement tied directly to the development of rice production occurred with the Boeraserie and Black Bush Polder Schemes. The previous schemes aimed at reducing the costs associated with repatriation were smaller in scale, typically limited in size to the area covered by seized estates along the coast. About 5,000 families (30,000 individuals) had been settled in these earlier schemes, collectively representing 70,000 acres of arable land (under 4000 acres per scheme on average, or about 14 acres per family - though the majority of individual holdings were much smaller, [Naseer 1978]). By comparison, Boeraserie and Black Bush Polder encompassed over 130,000 acres, making them the largest land settlement projects in the Caribbean and perhaps the most ambitious projects of their kind throughout the British Empire. The massive scale of these projects can be especially understood in the Black Bush Polder scheme, where settlers were each given 17.5 acres of land for cultivation, with 15 acres dedicated to rice production and the remaining 2.5 to be used for subsistence production ${ }^{43}$ (Naseer 1978).

${ }^{43}$ Though ear-marked for subsistence production, experience in the country dictates that the 2.5 acres available to settlers provides enough land for small-scale production of local market crops. 
Though different in their extent, their goals, and the means and measures necessary to create them, the Boeraserie and Black Bush Polder schemes faced common challenges surrounding the production of arable rice lands, appropriate drainage for those lands, and a means for defending both the land and the water network from the threat of excessive or saline water, which had the power to make these efforts futile. In Boeraserie, the concern centered around increasingly brackish canal waters, the potential collapse of the earthen dams used to delineate the boundaries of the reservoirs, and the potential for minor issues in one portion of the scheme to cause domino effects throughout the region. In Black Bush Polder, there were concerns over the regular flooding of the Canje River and its distributaries as well as the flushing of estate waters from the existing network of canals. In solving both of these issues, colonial engineers established a system aimed at social management as much as it was water meant to manage water.

Boeraserie

The estates and villages lining the coast of the West Coast Demerara region have historically relied upon the 94 square mile Boeraserie Water Conservancy, situated in the backlands between the Demerara and Essequibo rivers. However, inefficient design and poor soil conditions made the conservancy inadequate for large scale agricultural production. Though a complaint among the planters and villagers relying on it for decades, this inadequacy became painfully clear in 1937, when according to the narrative

The Boeraserie scheme, though technically a larger area overall, involved the rehabilitation and extensions of a large conservancy, making the amount of arable land and thus the amount available to individual settlers - much smaller. 
of the project application a drought left the conservancy dry for a period of 42 days $^{44}$. The lack of water caused the dam walls (mostly made out of local, peaty soil, see Chapter 1 - The Precolonial and Early Colonial History of Coastal Settlement) to shrink or collapse, leaving the areas adjacent to the conversancy - by this time mostly African villages or predominantly black towns having sprung up following the death of the local sugar industry - vulnerable to flooding. Similarly, nearby Canals Polder Conservancy, though much smaller in size and meant to provide water for a much smaller area caused regular experiences of drought and flood in the area of Canals Polder on the west bank of the Demerara River ${ }^{45}$. These problems with the Boeraserie Conservancy were first addressed by the Bonasika scheme, which created a canal from the Bonasika river to the conservancy to provide it with a regular infusion of fresh water. However, shortly after the scheme was completed, heavy rainfalls threatened to undermine the headworks, which resulted in the project's abandonment ${ }^{46}$. So severe was the damage that, in his notes of a tour of the decimated scheme, J.W. Vernon of the Colonial Office stated that "the water rushing through these headworks had scoured back so fiercely under the greenheart pile foundation that the diver who examined them was able to walk right

\footnotetext{
${ }^{44}$ Enclosure D: Boeraserie Extension Project Memorandum of Application, CO1031/170, The National Archives, UK

${ }^{45}$ Ibid.

Canals Polder is, interestingly, the only empolderment scheme developed by the Dutch. It has been excluded from this dissertation for this reason but will be the subject of future research.

${ }^{46}$ Ibid.
} 
underneath the whole structure. ${ }^{{ }^{47}}$ These issues, including water problems in Canals Polder, were to be addressed by the newly Boeraserie Scheme, which would, according to colonial legislators, also bring about thousands of new acres of arable land which could be worked by re-settled East Indian laborers, with the potential to grow a variety of crops $^{48}$.

Encompassing an area of 129,000 acres (201 square miles) with 97,000 acres available for cultivation, the Boeraserie scheme was an absolutely massive undertaking. While initially calculated to include not only support for rice and sugar but also for the ground staples common to African villages (see Chapter 2 - "A Mild Despotism of Sugar": Race, Labor, and Water Management), early reports on the economic prospects of the Boeraserie scheme quickly noted that the majority of the newly established arable areas would be used to develop the rice industry, while sugar expansion would be focused on the area of Wales Estate, West Bank Demerara ${ }^{49}$. This was due largely to concerns that the growth of non-cash crops would not provide the economic returns that cash crops (especially rice) could offer. One administrator made this point bluntly, "Leaving aside engineering, the doubtful part of the scheme from the technical aspect is the direction of agricultural developments. Unless the land is in fact developed with crops

${ }^{47}$ Notes of Tour of British Guiana by J.W. Vernon, December 1952 ${ }^{48}$ Minutes, CO1031/170, The National Archives, UK

${ }^{49}$ Enclosure C: Note on Agricultural and Economic Prospects of the Area Commanded by the Boerasirie Scheme, CO1031/170, The National Archives, UK.

The Wales Estate is an interesting project which is, as of this writing, under threat of closure and privatization by the Government of Guyana. It will be the site of future analysis. 
that pay, it will not be possible to charge water and other rates ${ }^{50}$." Falling sugar prices and low local market prices for other crops limited this to rice and thus, based on colonial agricultural racializations, to East Indian settlement.

This concern with the financing of the scheme through water rates (and thus seeking production for only specific crops) combined with racialized policies related to which racial groups would be targeted by and aligned for each agricultural project meant that, despite the longstanding African population in the region serviced by the Boeraserie scheme, the primary benefactors would be an East Indian populace who would receive land, housing, and preferential land tenure arrangements as a result of its production ${ }^{51}$. The positive effects for existing villages would be secondary - i.e. they would still benefit from improved drainage and through maintenance to some of the existing infrastructure, but there would be no major changes in economic or land tenure arrangements. According to some village residents I spoke with during fieldwork in the area in November 2017, this created some tension between newly settled groups and longtime residents which often collided with other racial biases.

\section{Black Bush Polder}

In 1957, a large portion of British Guiana's eastern region was uninhabited marshlands. The coastline between the Berbice River in the west and the Corentyne in the east were lined with relatively small sugar estates backed by an extensive and frequently flooded marshland. Being disconnected geographically, politically, and economically

${ }^{50}$ Minute of $26^{\text {th }}$ May 1952, CO1031/170, The National Archives, UK.
${ }^{51}$ See Minute of $18 / 3 / 1939$, CO111/766/5, The National Archives, UK 
from Georgetown, the depression of the sugar industry in the 1950s along with retaliation against organized laborers ${ }^{52}$ caused increasing levels of unemployment in the region, especially among the Indo-Guyanese population who could not readily find work in the Afro-Guyanese stronghold of New Amsterdam. Prior to establishment of the settlement scheme, much of this land was used for cattle grazing and the development of the scheme had to take this into account, with planners for the scheme noting at one point that "the invasion of cattle on to cultivated land discourages desirable agricultural practices such as crop rotation, the cultivation of permanent crops, etc. ${ }^{53}$ " Invasive cattle aside, the scheme successfully established thousands of acres of land for settlement and rice cultivation and soon saw settlers from around the region claim land to develop their rice farms. On April $7^{\text {th }}, 1961$, the scheme officially opened with great fanfare, including parades of settlers and speeches from important public figures, including Dr. Cheddi Jagan, leader of the Indo-Guyanese People's Progressive Party (see Plate 6, Plate 7, and Plate 8).

\footnotetext{
${ }^{52}$ An important part of this history of labor retaliation actually relates to the digging of new drainage ditches in what was then Plantation Skeldon. During a strike related to the mechanization of the first stage of ditch digging, colonial police fired tear gas and Greener Guns at protesting workers. The details of this event can be found in "Report of a Commission of Inquiry into the Causes of a Disturbance which Occurred at Skeldon on the $13^{\text {th }}$ of February 1957, and the Action Taken by the Police in Connection Therewith" 1957.

53 "Drainage and Irrigation for Cattle Pasture - Rear of Black Bush Polder," CO1031/3468, The National Archives, UK.
} 


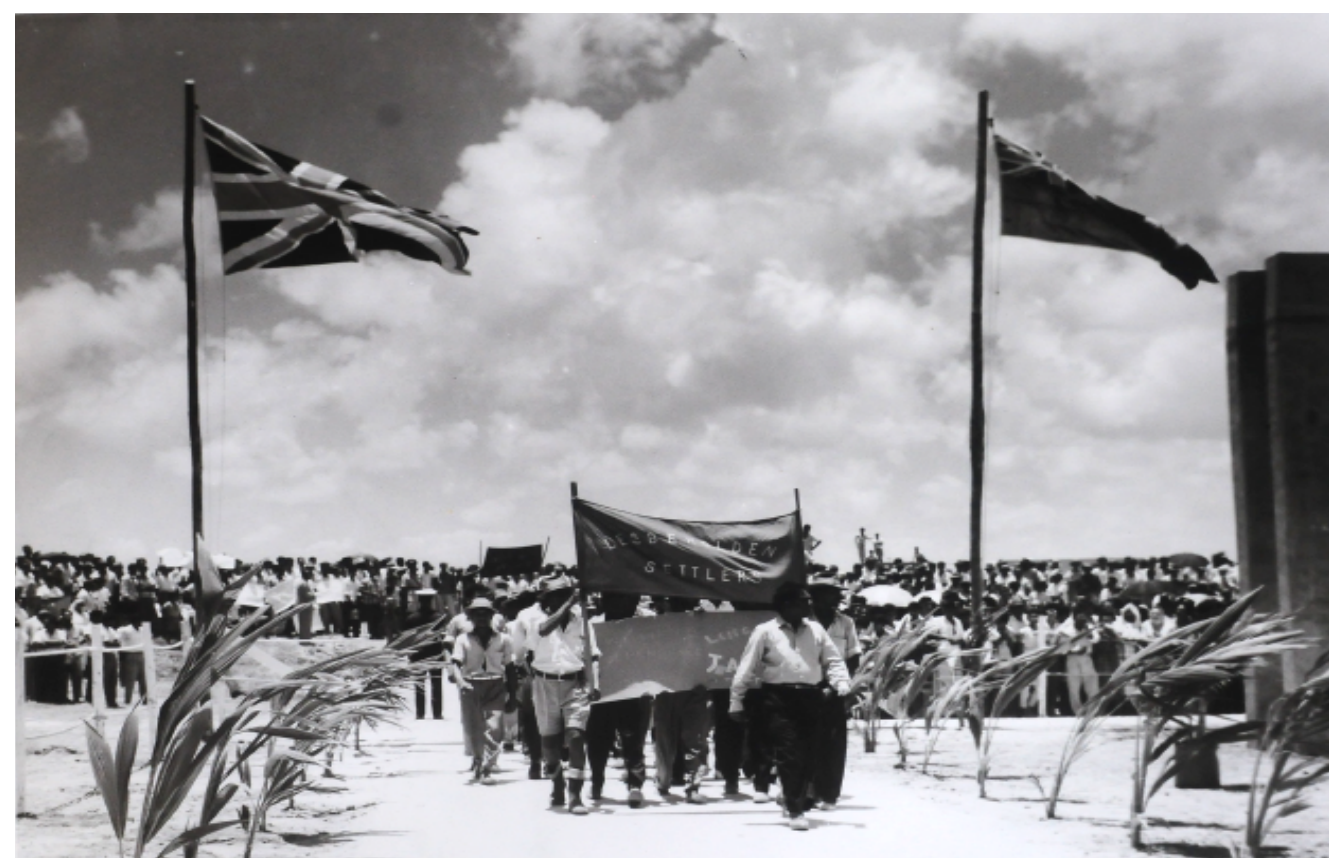

Plate 6 - "March past of settlers," Black Bush Polder Opening Ceremony, 7th April 1961, CO1031/3468, The National Archives, UK

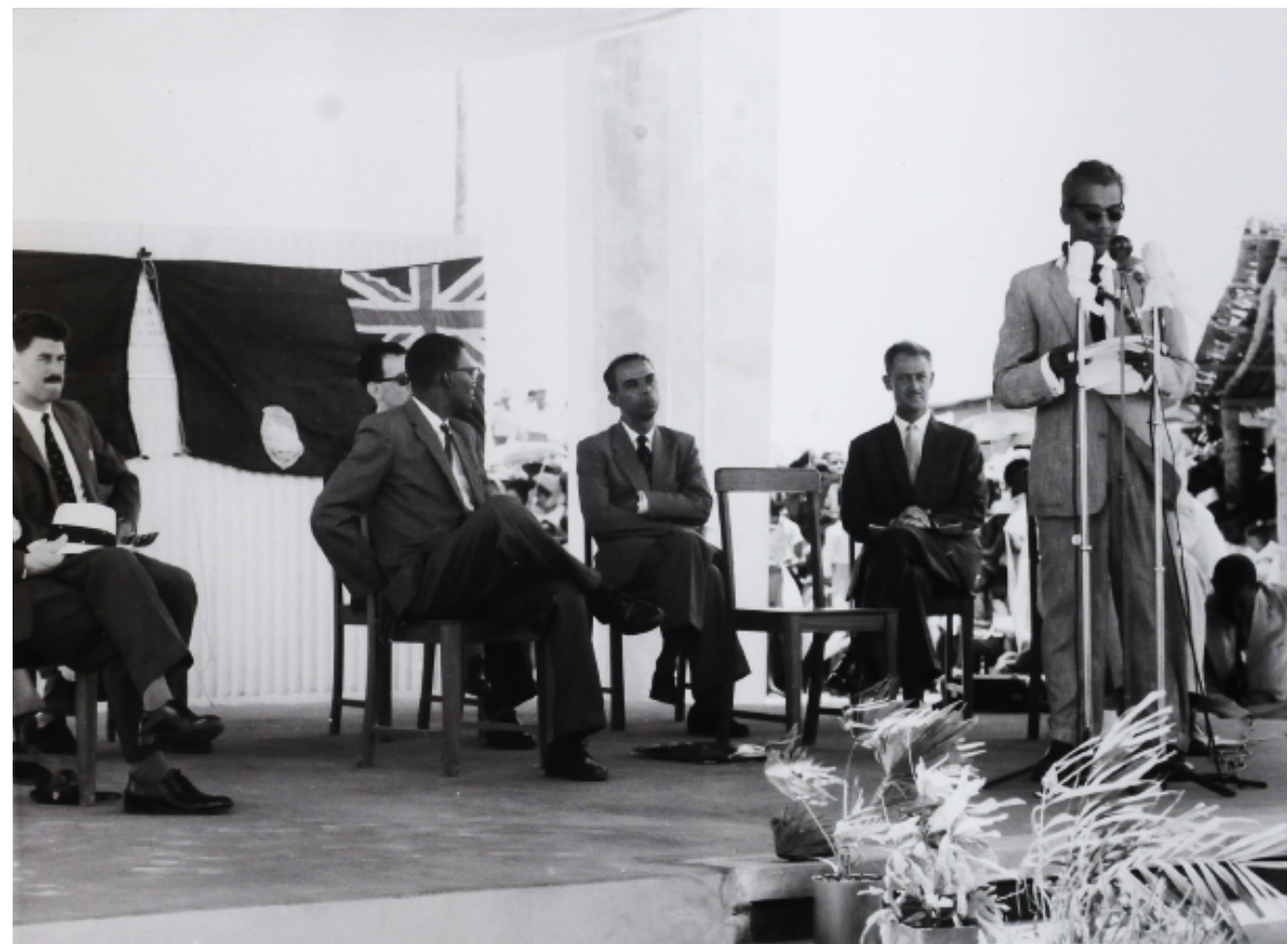

Plate 7 - "Platform Party. Dr. Jagan Speaking." Black Bush Polder Opening Ceremony, 7th April 1961, CO1031/3468, The National Archives, UK 


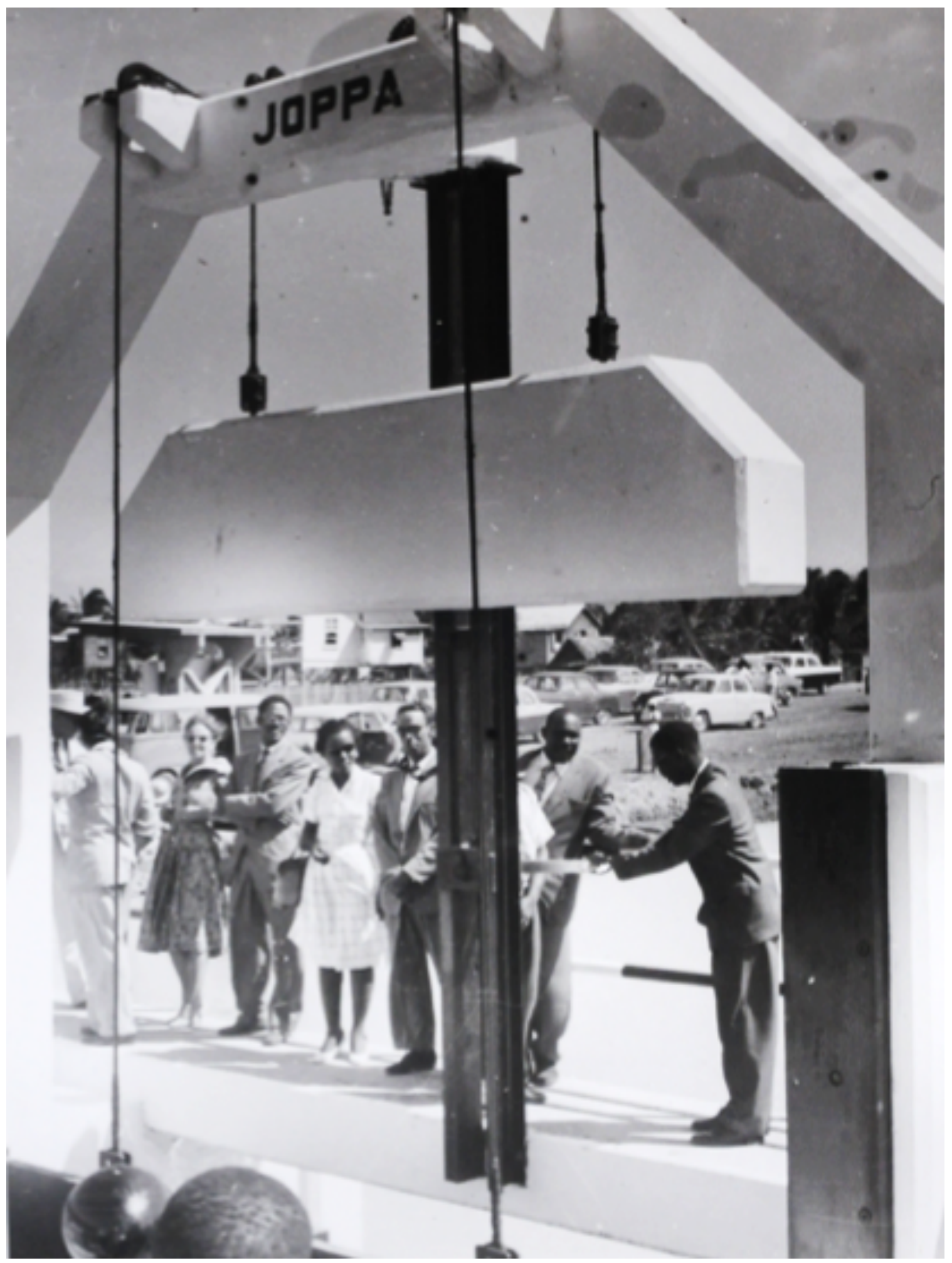

Plate 8 - "Mr. Benn, Minister, opening the Joppa sea sluice," Black Bush Polder Opening Ceremony, 7th April 1961, CO1031/3468, The National Archives, UK 
In what will be a recurrent theme, however, the excitement and success of the project did not last long. While initially run largely by the villagers, postcolonial development schemes established as part of the Burnham government's commitment to "cooperativism" saw the government take over capitalization projects and, in turn, saw the continued failure of many of the machines that made large-scale rice production a viable option, with cooperative rice mills incurring heavy debts that would need to be regularly written off by the parliament (Richardson 1972). The threats posed by this mechanical breakdown, along with those of drought, flood, blight, and pests meant that, within a decade, many of the settlers were "not full time farmers as those found in more developed nations where land, capital and labour are often devoted to the production of a single crop," creating a situation where both domestic and international intervention into the industry failed on the grounds that they did not account for local conditions and practices (Richardson 1972, 21; see also Lakhan 1994; Vining 1977).

As the first attempt in Guyana to establish new agricultural production in previously un-/dis-used land (Vining 1977), hopes were high for the Black Bush Polder scheme, but problems in the region persist. Black Bush Polder should have represented the culmination of more than a century of knowledge and experience with planning and development along the coast, from a fragmented, individualistic system which saw estates looking out for their own interests at the expense of others to a centrally organized system governed by groups who should have had significant knowledge of the conditions across the coast and thus - drawing on accumulated environmental and engineering expertise - develop meaningful and functional solutions. Instead, a postcolonial government that failed to provide education to settlers and cared little for their success 
along with settlers' understandable ambivalence toward monocropping combined to create a generalized and systematic failure of the scheme from the standpoint of both production and flood prevention (Lakhan 1994).

Chris Lakhan described the dire state of the scheme in the 1990s, stating that "it would be worthwhile if further recognition is given to the fact that the cumulative impacts of negative experiences, as for example water control problems, will act as a forceful deterrent to the successful cultivation, settlement and development of the coastal zone. As a matter of fact with its current water control and associated problems there is considerable disenchantment by many people in the coastal zone" $(1994,183)$. The situation has not significantly changed. In 2017, major flooding struck the area, devastating the region, a problem exacerbated by the fact that the design of Black Bush Polder meant that water flooding from the Canje River could not be adequately drained away (Williams 2017).

Tapakuma: Race, Rice, and Foreign Aid in the Postcolonial Period

On June $16^{\text {th }}, 1961$, the Tapakuma Drainage and Irrigation Scheme was created by an act of colonial legislation ${ }^{54}$. Combining two existing, smaller schemes, the goal of the project was to improve drainage in the area of Tapakuma Lake which, along with Lake Reliance and Lake Capoey, serves as one of the primary sources of fresh water for

${ }^{54}$ Savingram from the Governor of British Guiana to the Secretary of State for the Colonies, $1^{\text {st }}$ of July 1961, CO1031/3472, The National Archives, UK. 
rice cultivation in the Pomeroon-Supenaam region ${ }^{55}$. However, with origins dating back prior to the 1828 construction of Taksmu Lake (which was to be used as a conservancy), archival records show that the desire to have large swathes of cultivatable land along the northwestern coast was not new ${ }^{56}$. Prior to the completion of the Tapakuma scheme in the 1960s, planters settling the area had successfully strung together a series of canals that could be used to water crops and operated somewhat successfully in that way for nearly a century with little government assistance (Strachan 1980). By the 1930s the depression in sugar caused many of the estates to either close or significantly reduce their infrastructural expenditure, leaving the estate workers to deal with regular flooding and inconsistent crops (Strachan 1980).

While government funding for schemes in the area was scarce for most of British Guiana's history, it became a major focus when F.H. Hutchinson suggested redevelopment of the area as a means to promote the relative prosperity of its inhabitants ${ }^{57}$. The International Bank for Reconstruction and Development (a constituent member of the World Bank) disagreed with this assessment, stating that "absentee

55 "An Ordinance to Provide the Declaration of the Tapakuma Drainage and Irrigation Area and the Construction of Certain Works Therein," CO1031/3472, The National Archives, UK.

$£ 11 \frac{1}{\mathrm{~m}}$ Development Grants for British Guiana, CO1031/3472, The National Archives, UK.

"The Tapakuma Project," CO1031/3472, The National Archives, UK.

56 "Extract from Report on Drainage and Irrigation Works in British Guiana by D.S. Ferguson," CO1031/3472, The National Archives, UK.

${ }^{57}$ Ibid. 
landlords have failed to improve, or even to maintain, their drainage channels. Until land tenure here can be reviewed and thorough drainage of the farm lands guaranteed, the mission considers it inadvisable to spend heavy sums on irrigation" (International Bank for Reconstruction and Development 1953, 201). The colonial government acknowledged this assessment in the grant for the project but it was summarily ignored by G. Lacey, then the Secretary of State for the Colonies' advisor on irrigation, who argued the following year that "the fact, however, remains that the present unsatisfactory state of land development of the Essequibo coast must remain unremedied until the Government, by comprehensive scheme of irrigation and water control, secures effective control of the land ${ }^{58 "}$ (emphasis added). Thus, the goal of the colonial government was to use their ability to drain and irrigate the land as a means for taking control from absentee landlords in order to address issues of rural poverty in what remains even today a remote part of the coast. Once done, crown lands in the region would be given to settlers (drawn from those already living and working in the region) who could then compete with the absentee landlords and force an increase in the general maintenance and cultivation of the region ${ }^{59}$. Earlier colonial plans sought settlement in the area of what is now the town of Anna

${ }^{58}$ British Guiana Drainage and Irrigation Project: Tapakuma, Grant of £1,163,333. CO1031/3472, The National Archives, UK.;

"Extract from Report on Drainage and Irrigation Works in British Guiana by D.S. Ferguson," CO1031/3472, The National Archives, UK.

${ }^{59}$ Notes on the Discussion on Tapakuma Project on $2^{\text {nd }}$ December 1960, between Mr. W.A. Macnie, Director of Land Development, and Mr. D.S. Ferguson, Secretary of State's Advisor on Land Drainage and Irrigation, CO1031/3472, The National Archives, UK. 
Regina in the scheme but those were dismissed because the required outlay for the settlement "was altogether out of proportion to the benefits to be obtained. [...] [I]t has been decided that it would be more advantageous that the estate should be operated as a Government property on a small tenant farmer basis than as a land settlement. ${ }^{960}$ Thus, unlike the projects in Black Bush and Boeraserie, however, these settlers would not be provided with village lands or lands for their own cultivation. Instead, the government would provide space for rice cultivation and the settlers would need to work out other arrangements to meet their needs from the freeholders who controlled land near public road until a potential village site was found and built ${ }^{61}$.

The quasi-populist undertones found in the colonial office response to the International Bank of Reconstruction and Development (IBRD)'s concerns were matched in the undemocratic character of the bill that legislated Tapakuma's official creation, which proposed "to construct the works under the authority of an order of the Governor in Council with a view to avoiding the necessity of compliance with the lengthy procedure prescribed by the Drainage and Irrigation Ordinance whereby the proprietors in a drainage and irrigation area are given the opportunity of protesting against the construction of new works ${ }^{62}$." This would have the effect of undermining the power of

${ }^{60}$ Letter to Lord Lloyd of Dolobran, 5 October 1940. CO111/766/5, The National Archives, UK.

${ }^{61}$ Ibid

62 "An Ordinance to Provide the Declaration of the Tapakuma Drainage and Irrigation Area and the Construction of Certain Works Therein," CO1031/3472, The National Archives, UK. 
the landowners in the region to veto the spending in order to maintain their monopoly on labor. It also ensured that the project was done according to the desires of the government without input from either landowners or potential settlers. As permanent settlement of East Indian populations became a reality, Indo-Guyanese formed an interest group called the East Indian Association. The Association brought all manner of complaints to the government and tried to force them to respond or devise some kind of solution, which, perhaps more often than it should have, resulted in the government suggesting that problems facing East Indian populations would be solved via relocation in land settlement schemes ${ }^{63}$. Rising shipping costs and the increasing abandonment of sugar plantations led to increasing levels of unemployment in Indian communities. This had initially been addressed by "Grow More Food" campaigns beginning in the 1940s that were designed not only to decrease the amount of agricultural imports but also to reduce the duress experienced in Indian communities and feed "the progressive increase in population," but which were continuously disrupted by floods and droughts ${ }^{64}$ (see British Guiana 1941; Mullenite 2015). The largely Indian population already living in the area of

63 "British Guiana: Comments on the Report of the Land Settlement Committee," CO111/766/5, The National Archives, UK

Another document lays out another colonial attitude toward East Indian complaints. In one case, a representative suggested an issue be brought before the Secretary of State for the Colonies and the response from the colonial administrators was that "for political reasons, connected with the attitudes of Indian Congress towards the war, it was specially desirable at the present time to give sympathetic consideration" to their concerns. Minute 1A of 29/8/1939, CO111/763/3. The National Archives, UK.

${ }^{64}$ Minute of $4^{\text {th }}$ March 1943, CO111/778/22, The National Archives, UK 
the scheme were facing a similar promise, with neither group able to have a say in the planning process.

Financial records included in a grant application for the scheme show that with a total estimated cost of $£ 2,326,666^{65}$, the project intended to create a drainage and irrigation system capable of supporting 36,000 acres of cultivation with 20,000 acres being created immediately as part of the scheme ${ }^{66}$. This was to be done primarily by damming of the Tapakuma River in order to increase the storage capacity of Lake Tapakuma. The lake, along with Capoey and Reliance, would then be used to distribute fresh water during relative dry periods, serving largely the same purpose as the conservancies used in other parts of the colony ${ }^{67}$. Central to the creation of this project was the rice mill at Anna Regina, at the time the most modern mill large mill in the country $^{68}$. The goal was to continue on with what was assumed would be the successful launching of the Black Bush Polder Scheme in an effort to remove the country's extreme eastern and western peasant populations from an extended period of economic depression while continuing to diversify its economy away from an increasingly volatile sugar

65 Approximately $£ 49,325,319$ or US\$66,643,438 in 2017.

${ }^{66} £ 11 \frac{1}{4} \mathrm{~m}$ Development Grants for British Guiana, CO1031/3472, The National Archives, UK

British Guiana Drainage and Irrigation Project: Tapakuma, Grant of £1,163,333. CO1031/3472, The National Archives, UK.

${ }^{67}$ British Guiana Drainage and Irrigation Project: Tapakuma, Grant of £1,163,333. CO1031/3472, The National Archives, UK.

68 Ibid. 
industry, this time following along with the recommendations of the IBRD $(1953)^{69}$. Within a decade much of the hydraulic works for dedicated rice production had been completed and by 1965 - one year before Guyanese independence - land settlement projects began. The postcolonial government, forgiven of many of its colonial debts as a gift during the decolonization process, needed to do little more than provide maintenance funds to ensure the schemes success. However, cuts to Indian majority schemes spurned on in part from the bankrupt rice industry and in part to focus funds on developing other industries, including sugar and bauxite, all but ensured that this was not the case (Richardson 1970; Vining 1977).

By the late 1970s the Tapakuma project was in a state of disrepair. Sea defenses were crumbling, roads were impassible at times, and the rice industry was under constant threat of catastrophic inundation ${ }^{70}$ (Vining 1977). In considering projects to fund in 1978, the UK Ministry of Overseas Development (MoD) strongly considered and eventually funded large scale works meant not only to solve the issues stemming from the lack of maintenance but also to increase the region's economic productivity ${ }^{71}$. Their justification for taking on this project over others was simple: "the vast majority of the beneficiaries of the scheme will be of Indian race. The present Government in Guyana has tended to favour the Afro-Guyanese rather than the Indian element, and this could be held to

69 "Extract from Report on Drainage and Irrigation Works in British Guiana by D.S. Ferguson," CO1031/3472, The National Archives, UK.

${ }^{70}$ OD 50/52, The National Archives, UK.

${ }^{71}$ OD 50/52, The National Archives, UK.

OD 50/53, The National Archives, UK. 
constitute an argument for supporting the Tapakuma scheme ${ }^{72 "}$ (see also Khemraj 2016). Frustrated by Burnham's focus on growing the military and on his apparently unconditional support for African communities at the perceived expense of East Indian ones, the MoD sought to counter his power by providing services to the base of his main political opposition. In a letter to R.G. Taylor of the engineering firm Sir William Halcrow and Partners, who were at the time seeking aid funding to repair the failing Tapakuma scheme, a representative of the Ministry of State stated that "while it is true that the Guyanese are short of money and that sea water has breached the sea defences in several places, much of this problem stems from the fact that the Guyanese themselves are not according the work sufficient priority. While they are finding money for other things such as military expenditure, they have failed to provide the relevant Government Department with an adequate budget for a sea defences program." ${ }^{, 73}$ In this way, the financing of flood control systems was again used to affect the governance structures of the country, this time as a challenge to Burnham's hegemony at a time when he was actively legislating for the pre-eminence of the party over the state and displaying increasingly authoritarian tendencies (Hintzen 2004).

British interference appears to have worked. In his 1964 book Capital, Saving, and Credit in Peasant Societies (306), Raymond Smith described the situation thusly:

\footnotetext{
${ }^{72}$ Guyana: Tapakuma Irrigation Scheme and Sea Defence, OD 50/52, The National Archives, UK

${ }^{73}$ Draft Letter to Mr R G Taylor, OD 50/53, The National Archives, UK
} 
"Speaking very generally, one can say that the majority of the Negroes believe that the majority of the East Indians [...] are grasping, miserly, cunning, ambitious and ruthless and that they are well on their way to the ownership of the bulk of important economic assets as well as to the monopolization of prestigious positions in the civil service, the professions, and commerce. [...] The Indians tend to look down on the Negroes as being improvident, and more interested in dancing and drinking than in hard work, but on the other hand they accuse them of trying to hold on to a privileged position by discriminating against Indians for appointment to the civil service, teaching and even in the distribution of casual employment on public works department projects."

Likewise, during field work in the Tapakuma region in 2017, an Indo-Guyanese man described coastal flooding as "a black issue," saying it was a concern for Georgetown and the African villages but not along the Essequibo coast. An Afro-Guyanese man in the village of Den Amstel in the West Coast Demerara region expressed similar thoughts, saying that he felt the area was well taken care of during the Burnham period and that flooding was more of an issue for the cities and black villages rather than the larger coastal plain. Another Afro-Guyanese man also from Den Amstel suggested that the region had reaped the benefits of Burnham's regime but that the tide was turning, noting that the sea wall was increasingly broken and worn down due to neglect during the era of Jagan and the PPP from 1992 to 2015 (see Chapter 4). According to a number of coastal residents the current government - a multiracial coalition party led by the PNC - had seemingly moved past the racial politics of flood control and was focusing equally on all areas, perhaps to the extent of spreading themselves thin. One woman, an Afro-Guyanese 
teacher in the village of Uivlught near the Boeraserie scheme, expressed concern that this was effectively colorblind, and ignored the long-standing inequalities and hardships faced by both groups in favor a "feel good" policy (see Hardy, Milligan, and Heynen 2017).

Regardless of these specific positions and experiences, however, it remains clear that flood control has continued to serve as a technology of government in the postcolonial era.

\section{Conclusion}

These three schemes represent three of the major infrastructural engineering projects that took place in British Guiana between the end of the indentureship period and independence. As such, they offer a unique insight into the political economies of empolderment in the small colonial country, highlighting especially the ways in which political economic decision-making followed the contours of the broader racial politics at play in the region. At the same time, they show how operations of state and capitalist power flow through larger systems, beyond just the political and economic relationships they produce and are produced by. Though understudied compared to more typical water management projects, empolderment can amplify the inequalities present in other schemes in terms of the scale at which it occurs. This is because, as shown above, empolderment schemes carry with them not just politics of the infrastructure itself but also enable new forms of agricultural production and land settlement that carry with them their own material impacts and, potentially, inequalities. Important in this distinction are the scales at which these projects are occurring. As noted at the beginning of the chapter, a key difference between empolderment and other water and flood control schemes was 
the scalar coherence of empolderment projects compared to the relatively adhoc construction and subsequent governance of other drainage and irrigation works. In other words, administrating existing village and estate level systems varies significantly from administrating projects that are bound up with land settlement. This means that the scale of the projects, whether local, regional (i.e. county level), or colonial/national helps in part to determine what sorts of politics can become embedded in them and how this affects political economic considerations going forward. At the local level, empolderment projects served a simple function of providing land for Indian settlers whom the British could not fulfil their indenture contracts. But taken as a whole (i.e. at the scale of the colony), the projects also served a purpose of creating new economic, social, and geographical spaces for Guyana's Indian population that would later have important political impacts, as shown in the next chapter. This geographical distance has produced a variety of means for control and for the continued social independence of large swaths of Guyana's Indian and African populations. These divisions, in as far as they work to undermine the social solidarity necessary for actual socioecological resilience, continuously produce new forms of precarity even as they were created to avoid what would otherwise be a precarious situation for the colonial enterprise as a whole.

Since scale is an important part of understanding the ways in which people and environments interact in socio-ecological systems (Olsson, Folke, and Berkes 2004) and because understanding politics within these systems is an important part of understanding both the production and dissolution of resilience this also means that the scalar coherence of empolderment projects and the establishment of the rice industry had potentially different long-term outcomes for the resilience of Indian populations than African ones, 
even if the more general end result has been a continued vulnerability to flooding along economic lines. In this way, the genealogy of flood control projects begins to unfold in new directions, highlighting the broadly social aspects of flooding. However, it raises the question of how things might have been different if sugar was, from the beginning, as coherent or if the infrastructure for rice production had been created in a manner as adhoc as that which supports for the sugar industry. 


\section{CHAPTER 4 - COLONIAL PERSISTENCE: RACE, CLASS, AND FLOOD CONTROL SINCE 1966}

\section{Introduction}

The linkages between race, class, and flood control infrastructure during the colonial period are clear. Thus far, the genealogical approach utilized in this dissertation to understand flood control projects during the colonial period shows how they were often just as much about governing colonized populations through the infrastructure they experienced in their daily life as they were about building viable solutions to flooding. They were enwrapped by other colonial matters relating to racial relations; changes in local, regional, and global political economies; and became a key site in which colonial politics could be performed in as far as they could simultaneously address several of these issues in a single project. In Chapter 2, I showed how this governance affected African village populations during times of economic depression by keeping villagers tied to the sugar economy, thus bolstering it. In Chapter 3, I showed how land settlement schemes related to rice production created new social and economic geographies centered around race and racial stereotypes. But, how have these colonial-era projects affected the ways in which flooding was managed in the postcolonial period? How does flooding continue to manifest itself as a social or political problem with technological solutions and how are other projects of governance tied to these solutions? In this chapter, I answer these questions through an examination of the legacies colonial political-flood histories and the power they carried into the postcolonial period. 
Despite the criticisms made by scholars of neo- and postcolonialism that argue that the break between the colonial and postcolonial period is not as significant as it appears on the surface, in Guyana this does serve as a valuable point from which new analysis can be undertaken, particularly when thinking about the modes and forms of governance existing in the country around that time. In this regard, the break is not necessarily between the colonial and postcolonial state (which were similarly authoritarian in nature) but through the ways in which governance functioned and to what end. During the colonial period — as demonstrated above — governmental decisionmaking was largely oriented around the continuation of the colonial project as a whole and in particular the political and economic systems that made colonialism a worthwhile venture. With the end of colonialism and the start in earnest of the Burnham regime, things changed and the major focus on governance became on regime survival (see Hintzen 1989). While protecting the colonial system could be seen as a form of regime survival (in as far as colonialism itself is a regime), the postcolonial period made it about particular political parties and by extension about the people within those parties, a process that occurred along racial lines.

I begin by outlining the relationship between racial politics and colonial and postcolonial economic development, including a brief overview of the establishment of Guyana's racially-bifurcated two-party system and the movement for "non-capitalist" development through industrial nationalization in the establishment of Guyanese socialism, with a particular focus on the sugar industry. Though not directly related to flood management infrastructure, this provides important context for current flooding problems and government responses to them, especially as they are shaped by the 
continued reliance on the sugar industry to provide the bulk of the country's GDP and, significantly, coastal jobs. Next, I draw on public statements from the country's two major political parties and fieldwork conducted in Georgetown and Den Amstel in the fall of 2017 to understand the ways in which flooding continues to manifest itself as a political project. Finally, I examine these problems in relation to sea level rise and the new era of environmental engineering and management taking place along the coast. I argue that despite a shift from governance centered around political-economic development to one around political parties and their charismatic leaders, flood control has continued to play a major role in the governance of the country, affecting the ways in which people continue to experience precarity and thus resilience well into the postcolonial period.

\section{The Racial Politics of Development}

As demonstrated in Chapter 3, foreign interest in drainage, irrigation, and the racial politics associated with them shifted from the colonial office to development agencies, who used drainage and irrigation projects as a means for influencing the political situation in the country. This is in line with work in critical development studies that notes the political - and even colonial and imperialistic - influence of development projects in the postcolonial period (e.g. Browne 2006; Hayter 1971; Mahoney 2010; Smith 2008). Hayter (1971) and later Browne (2006), for example, argue that development projects always contain within a desire to provide external political influence on a population. For Hayter, this influence is imperialistic in nature, highlighting the uneven relationship between donor countries and aid recipients. For 
Browne, the relationship is more benign, with donors using their economic influence to ensure liberal, western ideals ${ }^{74}$. For many Guyanese, aid relationships were seen as largely parasitic and holding the country back. In the 1970s, the Guyanese political cartoonist H. Harris highlighted this sentiment with a comic showing Uncle Sam providing life support to a dying body while simultaneously draining its blood (see Figure 5). And as shown in the previous chapter, USAID and UKAID used development money aimed at flood control to undermine Guyana's newly independent government. Mahoney (2010) has likewise argued that postcolonial development is in itself an extension of the political economies developed during the colonial period along with the broader political and economic goals of the colonizing regime. With the extractive nature of Guyana's colonial period, it should then be no surprise that postcolonial development took on an equally extractive position. However, development in Guyana took another form that was intimately linked not only to desires for political and economic autonomy, but also to what would become a highly racialized struggle for competing socialisms.

${ }^{74}$ An idea which, in itself, replays the logic of colonial superiority. 


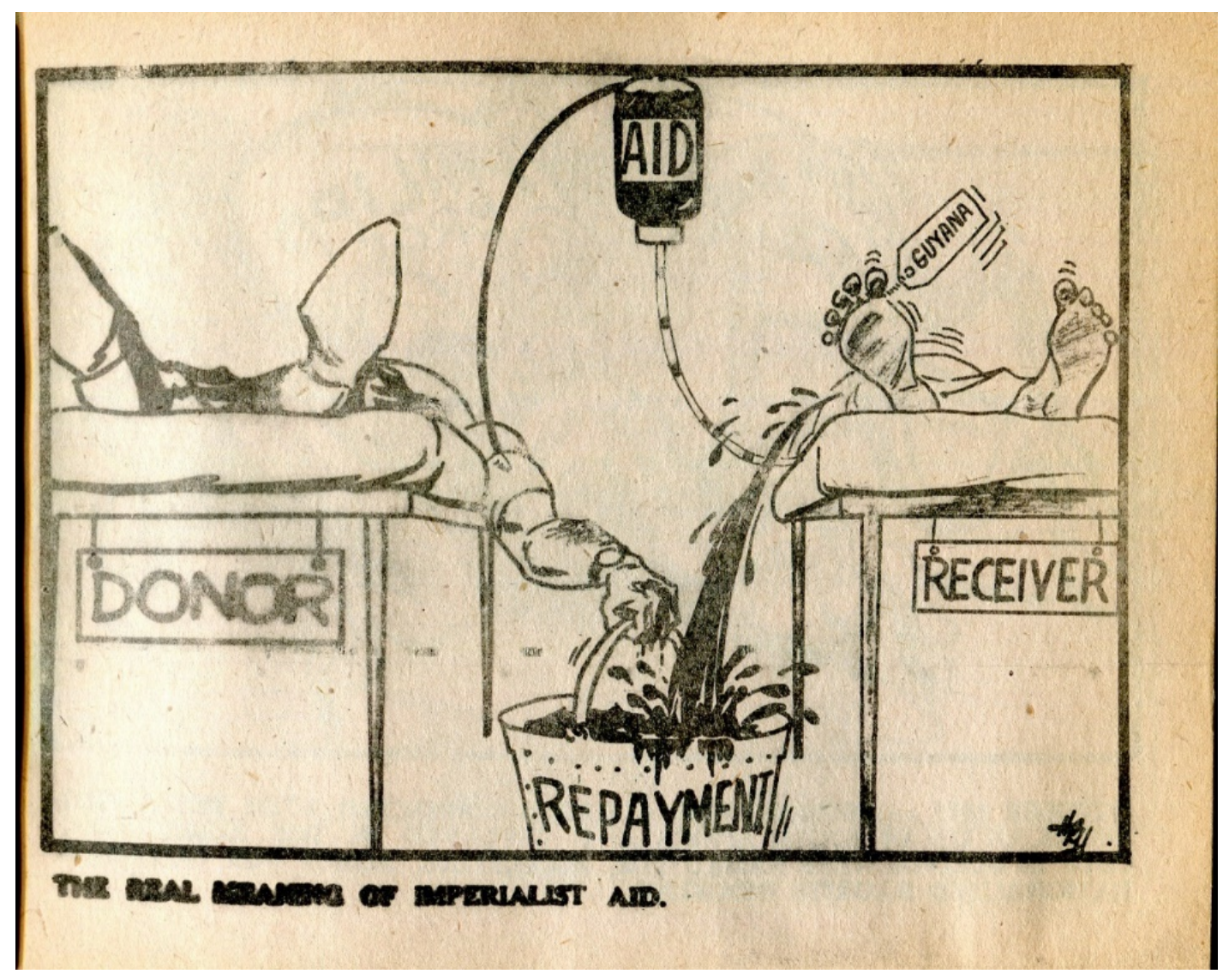

Figure 5 - The Real Meaning of Imperialist Aid - by H. Harris for The Mirror, Georgetown, Guyana

At the same time that the IRDB was developing a systematic plan for Guyana's economy focused on the increased expansion and protection of the country's colonial-era sugar industry (see Chapter 3 - Rice, Race, and Empolderment), an anticolonial movement was beginning fomenting among the ranks of the country's two largest unions: The British Guiana Labour Union (BGLU) and the Guyana Industrial Workers Union (GIWU), representing Guyana's dockworkers and sugar workers, respectively. This union emerged in part out of the Ruimveldt Riots mentioned in the previous chapter but was fomented by more radical actors in Guyana's union movement. Utilizing the 
multiracial sentiment of workers strikes and riots as a means for decolonization, the Guyanese dentist Cheddi Jagan, along with others, formed the Political Affairs Committee (PAC) with the goal of educating Guianese workers to the political and economic basis of colonialism (Premdas 1974). Using a Marxist-Leninist analysis, the PAC placed the blame for the poor conditions of working people in British Guiana in a colonial politics of disenfranchisement and property relations (Premdas 1974). In the PAC's analysis, the colonial state was used rhetorically as a common enemy of all Guyanese working people, existing primarily as a tool of class oppression at the hands of the colonizers (Premdas 1974; Hintzen 1989). This analysis, combined with relentless propaganda from the PAC, led to Jagan's election to parliament in the 1947 general election. It was during his tenure that a strike broke out among sugar workers at the Enmore plantation in 1948 leading to the shooting of some of the striking sugar workers by colonial police forces (see Venn, Sudell, and Smallman 1949). During this time, Jagan worked closely with the day-to-day operations of the strike, acting as a political voice for the striking sugar workers and their emergent - though not officially recognized - union, the GIWU (Premdas 1974). Meanwhile, other members of the PAC were infiltrating other unions, including the BGLU.

Having captured leadership positions in Guyana's growing union movement, the PAC transformed themselves into a new labor-backed, multi-racial, and anti-colonial political party, the People's Progressive Party. Though working among unions with different racial characteristics, Jagan's popularity rested primarily with Indo-Guyanese who saw in him one of their own (Premdas 1974). To unite the Afro-Guyanese and IndoGuyanese working classes under a single party, Jagan sought out a charismatic Afro- 
Guyanese counterpart in Forbes Burnham, a London-educated lawyer and expert orator (Premdas 1974). The goal of the PPP was to establish a party which would prevent voting along sectoral or racial lines. For example, if dockworkers and sugar workers voted for separate parties, the working classes would remain divided in the colonial system and never be able to take full control of the government, leaving elected governments to take a conservative and undeniably capitalist form.

It was under this united banner that the PPP would advocate for self-government and universal adult suffrage, succeeding in the latter and bringing about a new general election in Guyana in 1953, which they won. Despite the victory of the PPP in the country's first mass election, the party was deposed by British armed forces after only six months, reverting the political system to an autarchic form of colonial governance (Premdas 1974; Hintzen 1989). During this time, British Guiana's new constitution was suspended, Jagan was jailed, and Burnham was placed under house arrest after agreeing to cease any political activity (Hintzen 1989). Now separated, the two leaders of the PPP began to espouse different tactics and goals for the party going forward leading to their eventual split and the creation of a two-party, racially bifurcated political system that would persist for decades (see Hintzen 1989).

The PPP split into two factions in 1955 based on differences in goals for the country, with the Burnham-backed faction supporting federalization with the rest of the British West Indies and the Jagan-backed section vehemently opposing confederation and developing a more explicitly nationalist agenda. Though Burnham was originally brought in to garner the support of the black proletariat, the split and his initial support were not obviously racially motivated (Hintzen 1989). Within a year, however, both parties had 
moved from a class-based mobilization to one rooted in racial politics resulting in the resignation of the remaining black leadership in Jagan's PPP (Hintzen 1989). In the 1957 election, Burnham's new party did not receive widespread support, however, with Guyana's black middle class supporting the more moderate United Democratic Party (UDP). To overcome this, Burnham proposed his PPP faction merge with the UDP to create Guyana's first black political party, the People's National Congress.

After the formation of the PNC, US and UK intelligence agencies pushed for proportional representation. It was felt at the time that this would help insure against a government controlled purely by Jagan, who was later described as showing "the incompetence and bad judgement which is part of his character" and whose "half-baked attempt to apply communist doctrine threatened unrest and a complete breakdown of the administration." ${ }^{75}$ Despite electoral support from the colonial and imperial powers, however, the PNC did not easily take control of the country's political situation. In the 1964 election, the first to decide who would be the postcolonial leader, neither the PPP nor the PNC received the required 50 percent of the vote to form a government and, at the urging of the US, the PNC created a coalition with the conservative and United Front, with Burnham taking the role of the Premier and, upon independence, Prime Minister while UF members filled out ministry positions related to the economy (Rabe 2005).

The United Force was a relative newcomer to Guyanese politics, contesting their first election in 1961. However, they were filling a considerable void in the country.

${ }^{75}$ Guyana: 100 Days After Independence, $19^{\text {th }}$ September 1966, DO200/200, The National Archives, UK 
Though themselves a predominantly single race party with party members being almost exclusively of Portuguese descent, they eschewed the racial narratives being put forth by the other parties and instead offered a class-based perspective on Guyana's situation. At the same time, they also explicitly opposed themselves to the economic policies of both Jagan and Burnham and offering an economic vision that relied heavily on private sector growth. These two factors combined won them the support of Amerindian groups, white ranchers in the deep hinterland savannahs, and Portuguese residents who had otherwise been left out of the country's political processes entirely (Sanders 1972).

For the US and UK, a coalition between the PNC and UF was a win-win. Jagan's party, though still holding a bulk of the parliamentary seats, would not be able to enact legislation on its own or continue to build official political and economic relationships with Cuba and the Soviet Union. However, with their simple majority, they would remain vested in the parliamentary process. On the other hand, Burnham, though himself a socialist, would be tempered by a conservative and pro-capitalist party who would work to keep government spending in check, allowing for economic development to occur through investment from the foreign private sector as it had in other recently decolonized countries. Likewise, the coalition guaranteed that the PNC would need to rely on UF votes on parliamentary measures, ensuring that Burnham's more radical positions would not become official.

The relationship between the PNC and the UF was contentious from the beginning, with their problems arising primarily - and perhaps predictably - from differences over how government funds should be spent in support of the new country's 
development program. ${ }^{76}$ By 1966 the threads were beginning to show. With Jagan beginning to campaign against the lack of development in the first two years of the PNC government, Burnham was anxious to spend development money and put forth largescale projects which would help his public image and bolster his chances for re-election in 1968. The Treasury, staffed primarily with ministers selected from the UF wanted to keep government spending low and create favorable conditions for foreign investment. ${ }^{77}$ The frustration led to the resignation of one of the ministers in lieu of being removed from his position and Burnham taking direct ministerial control over economic development. ${ }^{78}$ D'Aguiar and the UF, however, stayed committed primarily to a focus on the "Puerto Rican Model" of development advocated for by Sir Arthur Lewis, which relied on attracting foreign capital in the private sector to stimulate the economy and provide a source of funds for other development ventures (Pierce 1984).

Despite the growing differences between the two parties, foreign governments remained committed to a Burnham-led coalition for the 1968 elections, if only because it appeared better than the alternative: a Jagan-controlled government in which it would be the USSR, not them, asserting political influence in the region. In reviewing Burnham's

\footnotetext{
${ }^{76}$ Letter from Martin Reid to D.M. Cleary. DO200/200, The National Archives, UK 77 The differences between D'Aguiar and the UF and Burnham and the PNC were described by the Dominions Office as so: "Mr. D'Aguiar is a dour figure with a deep dislike, which he does not conceal, of Mr. Burnham's flamboyance and extravagant tastes, and the irresponsible way in which Minsters incur expenditure which he thinks unnecessary." Guyana: 100 Days after Independence, DO200/200, The National Archives, UK

${ }^{78}$ Ibid.
} 
first years in office, the British High Commission in Georgetown credited Burnham with reducing racial tensions in the country, reducing the unemployment rate, and working toward a coherent development plan (even if it was at the expense of the coalition with the UF). ${ }^{79}$ Burnham's government may not have been where they intended it to be, but it was at least moving in a direction they deemed to be worthwhile. Based on this, and with the help of the CIA and AFL-CIO, the PNC-UF coalition government was able to remain in power after the 1968 elections (see Rabe 2005).

By 1970, political conditions in Guyana took a dramatic turn. Through continued maneuvering of cabinet positions and a complete disregard for D'Aguilar's economic policy recommendations, Burnham had successfully shed the capitalist weight of the UF and began working on his plan to develop the country on his own terms, including a sharp turn to the left even from his previous Fabianist tendencies (Pierce 1984). Increasingly he began adopting socialist rhetoric, building alliances with other socialist states, and seeking industrial nationalization as a means for economic development that did not rely on or replicate the conditions of colonial capitalism into the postcolonial era (Pierce 1984). On the $14^{\text {th }}$ of December 1974, Burnham delivered the now-infamous Declaration of Sophia in which he stated, "the Party should assume unapologetically its paramountcy over the Government which is merely one of its executive arms" and declared "That ours is a Socialist Party, committed to practising Co-operative Socialism"

${ }^{79}$ Guyana: 100 Days after Independence, DO200/200, The National Archives, UK 
(Burnham 1974). With this change in platform, Burnham moved forward on plans to nationalize the sugar industry.

Burnham had hinted at nationalizing sugar before. It had been an official part of PNC policy since 1964 and, at an April 1970 meeting of the Commonwealth Caribbean Heads of Government, Burnham re-iterated his commitment and shortly thereafter began the process of nationalizing the Demerara Bauxite Company ${ }^{80}$ (Shahabuddeen 1983). Perhaps feeling increased pressure, Bookers - the largest sugar producing firm in the Caribbean - agreed to transfer all sugar lands not currently under production to the Government of Guyana in 1973 (Shahabuddeen 1983). This, for Burnham, had two effects: first, the sugar firms were finally out of practice of housing, ostensibly giving a role to the government to address housing issues for the last time. Second, it showed that, if pressed, Bookers would bend. As Shahabuddeen $(1983,265)$ notes, Burnham's initial move with this change in land ownership was to tie future sale and government acquisition of sugar lands to national policy. By 1975, the government had used its new policy to nationalize Jessel (the smaller of the two remaining sugar firms), stating that "in the circumstances [the] PNC Government has decided that the continued operation of that company here is contrary to and inconsistent with the national interest" (quoted in Shahabuddeen 1984, 267). Bookers was nationalized the following year after negotiation with the government.

${ }^{80}$ A second bauxite company owned by Reynolds would be nationalized in 1975 . 
Walter Rodney, then considered one of the leaders of Guyana's third socialist party - the multi-racial Working People's Alliance (WPA) -criticized Burnham's socialism and its nationalistic tendencies as a means for establishing "dictatorship in which the state control over the economy was the main weapon used to keep people in line” (Rodney 1981c, 68). Likewise, despite supporting socialist policies in general and nationalization of the country's major industries in particular, the PPP did not feel that the PNC was working in the best interest of the people and describing the state-owned sugar industry as "already in a state of permanent debilitating crisis" by the mid-1980s (Collymore 1984, 1). Nationalization also had a secondary effect that is often overlooked but is important to this dissertation: it placed control of the bulk of the drainage, irrigation, and other flood control schemes firmly in government hands, meaning failures could no longer be passed off without drawing at least some criticism. As noted in the previous chapter, this provided a space for foreign governments to enter into the country and influence the situation through development assistance, a position that was not widely supported. But perhaps even more significantly, it created a situation in which flooding became a site of argument between the PNC and PPP regimes.

\section{Understanding Modern Drainage and Irrigation Problems}

From the mid-1970s to the late 1990s there is little in the way primary or secondary source information on specific flood events in Guyana. While flooding remained an object of inquiry in the Guyanese scientific community (see e.g. de Beer and Bacchus 1992; Pelling 1997; 1998; Shaw 1987; Singhroy 1998) they weren't particularly politicized nor, apparently, were they newsworthy. Several people I spoke to in 
Georgetown and the surrounding areas during my fieldwork in 2018 acknowledged that there was flooding during these periods but had no specific comments about particular flood events or even their general characteristics. The Walter Rodney National Archives also had little to offer in terms of materials related to flooding during this period. Outside of a handful of PPP propaganda pamphlets that mentioned failing infrastructure in vague ways, there is little available. This isn't to say that the floods that did occur were not significant for some, but that the general sentiment was that floods during that time were overshadowed by what was to come.

Today, however, the drainage and irrigation system in Guyana is closely watched. Following major floods in 2005, 2006, and 2015, engineers and policymakers have become acutely aware of the need to balance demands for coastal drainage while also maintaining the water levels in the various conservancies to prevent both overtopping and drying out of conservancy dams. Especially when, as the local economy shifts from one based on sugar to a multitude of other goods, less water is used to draw down local conservancies. This is what happened in January 2005 when heavy rains caused water to spill freely over conservancy walls, flooding southern Georgetown and villages throughout the East Coast Demerara region. During the floods, as much as six feet of water covered the village of Plaisance while residents of South Ruimveldt on the opposite end of the capital city saw water enter their homes and businesses. Water stood on the streets for several days, impacting the ability of children to go to school and adults to go to work. These conditions were repeated the following year, although to a lesser extent, when winter monsoon rains once again caused the conservancy to overtop and flood 
waters to fill Georgetown's streets ${ }^{81}$. These large flood events have created a situation where now more than ever drainage and irrigation are understood as a system where weakness in one area could have devastating impacts in other areas. This has not, however, made the racial components of flooding and flood vulnerability less visible.

As Sarah Vaughn (2012) has argued, the 2005 floods were used to maintain social divisions through the deployment of state-sponsored environmental expertise. Slow information cycles and inadequate response from government agencies meant that many Guyanese were left to handle and recover from floods with little assistance until the PPP began responding. Even then, environmental expertise was mobilized and circulated in ways that were counter to those of flood victims. From this technical incompetence, Vaughn $(2012,3080)$ argues that "accusations of racism, chauvinism, and subjugation between the state and international aid organizations and across different racial populations in Guyana" flourished. This created entry points for the PNC to undermine state-sanctioned disaster narratives and produce counter-narratives of their own which could then be used to mobilize their racial-political party supporters.

While the PNC felt the PPP handled the 2005 floods poorly, and argued that they could have done more, it was only when they began actively campaigning for the 2006 election that such rhetoric began to take a position of importance in their policies. When flooding broke out again in the early days of 2006, they were quick to attack the PPP and

${ }^{81}$ Information on the specifics of the floods comes largely from two civil engineers who worked with the PPP government to address shortcomings in the system after the second flood. These interviews took place in October 2017 in Georgetown and are not included as part of the total interview count. 
argue that this is reflective of PPP leadership. The earliest of such attacks took place on January 6, 2006, when the PNC (now called the PNC-Reform, or PNCR) called for a permanent disaster task force and criticized then-president Bharrat Jagdeo for micromanaging the situation in an attempt to "gain political mileage" and noted how Jagdeo and the PPP administration were quick to blame the flooding on the regional administration in the affected areas when it became clear they could not handle the situation adequately ${ }^{82}$. In the weeks to come, the PNCR would continue its attacks, arguing that the government was made aware of the situation facing these regions a month prior and that they had adequate time to address many of the infrastructural issues causing flooding, particularly given the fact that many of these areas were also affected in the 2005 floods $^{83}$. On January 19, 2006, the PNCR released a scathing press statement accusing the PPP of failing to live up to its promises of improved flood management, tied this failure to other failures experienced in the previous two decades of PPP rule, and noted the advancement of flood defense during the PNC governments of the 1960s, 70s, and 80 s. By the time of this release, floods were being fully utilized as a way for the PNCR to position itself as the responsible alternative to the standing government during an election year.

Up to this point, the PNCR position with regards to the flooding had largely ignored racial division between the two parties, instead focusing primarily on the relative inability of the government to adequately address the country's needs and the historic

${ }^{82}$ Press Statement by the People's National Congress Reform [PNCR], January 5, 2006 ${ }^{83}$ Press Statement by the PNCR, January 12, 2006 
precedence of the PNC sufficiently handling issues of flooding. However, in a January 26 press release, the PNCR accused Jagdeo and the PPP of "subliminal racial politics" in their characterization of flood related protests in several predominantly Afro-Guyanese communities, going so far as to tie Jagdeo's statements on the protestors to the colonial rhetoric used to divide the Afro- and Indo-Guyanese historically ${ }^{84}$. They likewise argued that the PPP administration was engaged in practices of discrimination with regards to the management of flood relief monies in the aftermath of the flood ${ }^{85}$. The racial divisions at play in this context serve to naturalize and legitimize the social hierarchy in the country in which a party with historical support from one of the major ethnic groups can place itself in a superior position compared to members of another (Brahinsky, Sasser, and Minkoff-Zern 2014).

By the second week of February 2006, much of the discourses surrounding the floods specifically had died down with the PNC focusing on other differences between themselves and the PPP government, particularly their political and economic policy. However, the floods would remain a key point of contention during the PNC's 2006 electoral campaign and would remain a key motivator for years to come. In June of that year, the floods emerged again as a crucial point in the PNC electoral campaign, with the

\footnotetext{
${ }^{84}$ Press Release Flood Woes: Luncheon's Statement and Jagdeo's Actions - Submlinal Racial Politics, PNCR, January 26, 2006

${ }^{85}$ Press Release Response of the PNCR to Attacks on the Party and its Leadership, December 18, 2008
} 
party again noting the failure of the government to respond adequately to the previous year's floods:

"We expected that the Government would have learnt the lessons so clearly taught by the disastrous 2005 floods which ruined so many lives and set back our national economy and that they would have put the necessary systems in place to enable affected citizens to cope with such events. [...] Many of the reports which assessed the 2005 floods made comments and recommendations which should have been taken seriously by a Government which had the interest of the people at heart." 86

Despite this rapidly escalating political discourse surrounding flooding in Guyana, neither the PNCR nor the PPP directly acknowledged the role of the country's political economy of the long history of flood control projects (and their failures) in affecting not only the perceived severity of the flooding but also its role in perpetuating the risk of flooding (cf. Pelling 1999). Despite the connection among the drainage and irrigation system, the country's political economy, and colonialism, political economic changes that move away from those used to bolster the colonial economy are never offered as a means for mitigating the risk of experiencing flooding as a disaster. Political economy was a key focus for both parties electoral campaigning and, for the PNCR, was included in several press statements and releases that spoke directly to the country's continuous experience

${ }^{86}$ Press Statement by the PNCR, June 15, 2006 
with flooding, but the two were never connected. The focus on the PNCR in this section is not meant to dismiss and relieve the role of the PPP in politicizing flooding. However, as the opposition party in a country where much of the media is owned and controlled by the state, the PNC made all their positions clear in statements and releases to the press where the PPP, largely, did not. Many public statements by the PPP have not yet been made publicly available and are missing from the digital archives of the state newspaper, the Guyana Chronicle. However, PPP actions can be understood through the context of the above analysis of the PNC. It was not just the PNC who tied flood response to the country's racial politics, for example, but also the PPP by commenting only on protests occurring in black areas and referring to the protestors as "thugs." Likewise, blaming the rainfall for the disaster rather than focusing on the political economic causes or the failures of infrastructure served to do little more than work as excuses for the regime, reframing the discussion away from the failures of the state even as those failures are being made explicit by the opposition (see Olson 2000).

After losing the 2006 election, the PNC used the 2006 flood as a point of reference for several years to come. In 2008, when the PPP attacked the character of the PNCR and its members, the PNCR referenced explicitly the 2006 flooding in its response, asking "Who was it that exposed the gross mismanagement, discrimination and corruption within the Government Flood Relief program? The PNCR did not only 
criticize and expose, but vigorously organized its own National Relief efforts and provided support to all communities regardless of race or politics." ${ }^{\prime 87}$.

After losing the 2011 elections, the PNCR formed a coalition with other local opposition parties called A Partnership for National Unity (APNU). Like the previous coalition formed to defeat the PPP in the 1960s, the APNU is a multi-ethnic group with membership from a number of differing political ideologies. Despite this, the 2006 flood and the PNCR response has remained a key point for their platform, particularly in the run up to the 2015 general election, which they would win. In 2014, after a series of floods across the coast, under their new coalition name of A Party for National Unity (APNU), they argued that "the PPP/C Administration seems to be unwilling to learn from past experience, unable to conduct a comprehensive investigation to determine the causes of recurrent flooding and unprepared to implement measures to notify the populace and to mitigate the impact of this hazard. APNU asserts that, notwithstanding the extraordinary rainfall, much of the human discomfort was caused by mismanagement and neglect." ${ }^{88}$. Thus, the 2006 floods and the racially divided political maneuvering that followed them remain an important waypoint in Guyana's recent political history.

Despite the PNC's arguments that flood responses were racially motivated, most of the people I spoke to in Guyana were not as convinced. Between September and November of 2017, I spoke to 52 people of various ages, classes, political affiliations,

${ }^{87}$ Press Release Response of the PNCR to Attacks on the Party and its Leadership, December 18, 2008

${ }^{88}$ APNU, Press Release 8 Dec 2014 
and racial/ethnic identities about flooding in Guyana and the government response to them. Of these, 10 allowed me to record our conversations ${ }^{89}$. Regardless of recordings, interviews lasted between 30 minutes and an hour and a half, although I met several times with some of those who wouldn't allow me to record them and those interviews, combined, lasted for several hours. The object of my interviews was not to develop a general consensus of the government response to floods, but to instead understand the ways in which floods impacted individuals from different backgrounds. Six of those who allowed me to record our conversation were men and four were women with ages ranging from 25-70. Five lived in the greater Georgetown area and had directly experienced the 2005 and 2006 floods, four lived in Den Amstel - an Afro-Guyanese village in the West Coast Demerara area, and one was a minibus driver who lived near Tuschen, on the east bank of the Essequibo, but whose route took him from Georgetown to the Essequibo port town of Parika.

In general, people I spoke to felt that the fact that flooding disproportionately impacted the Afro-Guyanese community was an unfortunate consequence of the country's colonial-era cultural geography and that the racialization of them was little more than politicking. Michael, an Indo-Guyanese chemical engineer, and Rachael, an

${ }^{89}$ There was a significant pushback when it came to recording conversations that was not expected when planning for this research. In conversation with a number of Guyanese academics about this, most felt as though it was the result of a general distrust of white researchers while others said it was likely related to the proliferation of online news outlets that has occurred recently. Out of a fear of alienating people who would not let me record our conversations, I never pushed the issue and instead took notes either during our interviews or immediately after. In future research, it may be worthwhile to offer a survey mechanism in addition to semi-structured interviews. 
Afro-Guyanese government employee speaking to me in a non-official capacity were both effected by the 2005 and 2006 floods as residents of South Ruimveldt but both felt that the PNC missed the mark in their criticisms. For Michael, the fact that some neighborhoods flooded and others didn't was simple geography. Kitty - an IndoGuyanese community adjacent to the seawall on the northern edge of the city - for example, did not flood as badly as nearby Ogle and Plaisance because they had a longexisting and well-functioning drainage pump and sluice gate. Newly incorporated parts of the city, like South Ruimsveldt and Ogle did not; neither did the village of Plaisance which still shared primary drainage facilities with Beterverwagting. Michael's frustration with this situation was, however, clear as he told me he felt that the relatively high taxes in the country could be going to addressing these issues. Earl, a retired civil engineer and lifelong resident of the Cummingsburg neighborhood in central Georgetown echoed this sentiment, saying that the government was wasting rates by focusing on pumping when they should have been addressing flow and evaporative characteristics of the canals.

For the past decade, Earl has documented every flood event in Georgetown in order to find a natural pattern, one which he claims has not yet shown itself. Instead, flooding seems to occur when water cannot be evacuated quickly enough and when it does not have time or space to soak into the ground, a common occurrence. After the 2006 floods, he noted that a new large pump was installed in South Ruimsveldt to alleviate flooding in the area but that the pump was so large it could never maintain adequate head pressure and could thus only be run for a couple of minutes at a time. Despite this shortcoming, the government declared it a success. At the same time, residents throughout the city had continued the process of concreting their yards in order 
to mitigate the social and economic impacts of the floods despite knowledge that this actually increased their likelihood. For Rachael, this was the case for her family property which was concreted so that she would not have to miss school and her mother would not have to miss work as they dealt with accumulating mud. Earl himself "empoldered" his yard, concreting and grading it to fill a small ditch which he pumped himself into the city drainage system. Adequate government response and actual maintenance of the existing system, they felt, would have prevented the need for both bigger pumps and household level mitigation strategies. They all agreed that the racial arguments put forth by the political parties were simply ways to mask these inadequacies and appeal to the rural populations who had much less (and significantly different) experiences with floods.

There was also a clear indication that people felt that the current governing coalition - APNU - were taking flooding seriously, even if the country still faced challenges. As Mary, a 25-year old woman from Den Amstel explained, the current government is bringing in a lot of outside help in order to address local issues of flooding. While not opposed to this, however, she was concerned with the motivations of western actors, especially in a time when Guyana was receiving global recognition for its newly discovered offshore oil and gas reserves. She was also concerned that this outside help might replay some of the uneven exchanges of the colonial system but in innovative ways and at the expense of local knowledge about flooding, stating that "People want the Dutch to come back to stop the floods. The Dutch didn't build the canals. Slaves did." 90

${ }^{90}$ Interview on October 14, 2017, Georgetown, Guyana 
When I asked her to expand on this powerful statement she said she felt as though Guyanese have enough experience with floods and enough experience dealing with them that they don't need the Dutch - or any other Western power - to intervene. Although the Dutch have been advertising themselves as global experts on coastal flooding due to their historical and geographical position, Guyana has a history of its own and should have the knowledge and capacity to do it on their own, even if it means eschewing current political divisions and economic commitments. Thus, attempts by the government to bring in foreign help for floods does nothing to empower Guyanese to handle these issues and leaves them instead in the hands of wealthy, Western powers who will design systems that continue to ignore local cultural politics and landscape knowledges. Mary was also concerned that APNU's focus on solving everyone's problems equally and with the same policies let deep-seated racial scars fester in the name of superficial equality without a focus on producing environmental justice. By ignoring the past twenty-five years of PPP rule — which she felt often benefited Indo-Guyanese communities — the inequalities developed during those times (some of which have much longer histories) meant that Afro-Guyanese would continue to suffer greater consequences relative to their IndoGuyanese compatriots.

Mary's comments illuminate two clear parts of current issues to local flooding. First, it highlights the continued violence of the colonial experience. Though Mary is not old enough to have ever experienced colonialism first hand, she felt as though what she was seeing was in line with what she had learned about the country's colonial past. Second, she highlighted the importance of a focus on the racism inherent in "color-blind" approaches to coastal flood management (see Hartman and Squires 2010; Harden, 
Milligan, and Heynen 2017). Although most of the people I spoke with, including Mary, had faith in the government to overcome these barriers and find more equitable solutions, one man did not.

$\mathrm{BD}$, the minibus driver from Tuschen, told me that in his age and the decades he has spent driving Guyana's coast, he doesn't have any faith left in the government to adequately address flood issues (or really any issues facing the country). A supporter of the WPA in the 1970s, BD now feels as though the government has little to offer the "small man" and that Guyanese should instead focus on solving flood problems (among a multitude of others) themselves. He acknowledged the racial components of flooding, highlighting the ways in which Afro-Guyanese communities benefitted from PNC works while nearby Indo-Guyanese villages became the sites of pilot projects cooked up by the PPP government in the 1990s, but didn't feel that this was because of racial prejudice by the politicians. Rather, he - like others - said that these were a way of appealing to the voting bases of the parties and that this would be the case so long as the parties remained divided along racial lines. When asked if he thinks the current government - which is multi-racial in character - is doing things differently he explained his position succinctly, "I don't vote and I would never vote because I believe in people." ${ }^{91}$ He suggested to me that if everyone stopped worrying about the government doing things or getting government approval before acting and just started addressing issues as they occurred in a collective and communal way, Guyanese society as a whole would be better for it.

${ }^{91}$ Interview on November 18, 2017. Conducted as I rode with BD along his bus route. 
BD recalled that both the PPP and the PNC before them had called on the Dutch to solve flooding issues in West Coast Demerara and while their solutions worked for some or in the short-term, they left other people vulnerable. As we drove along the public road, picking up and dropping off passengers along his route, BD pointed out the many places where the sea wall was degraded and where Dutch designs meant to redirect ocean tides had failed to account for the tremendous wave action and sedimentation of the Guyana current. He also identified areas that were once dense with mangroves planted by the PPP, but which were now exposed to the sea. His commentary proved prescient. On March 2, 2018, unusually strong spring tides caused ocean water to overtop the sea walls causing considerable damage in the West Coast villages that $\mathrm{BD}$ said would be a problem (see Plate 9). Effecting some three hundred residents of the coast, the flood damaged homes and businesses in the pre-dominantly Afro-Guyanese region. Minster of Public Infrastructure David Peterson said that the overtopping had caused severe damage to the tops of the sea walls, but as BD had noted nearly four months prior, the broken parts of the walls were already in poor condition (Chabrol 2018), owing according to some locals to decades of neglect by the Indo-Guyanese government in favor of mangrove planting which had little long-term effect in the area. While long-term government response to these issues remain to be seen, it highlights the ways in which certain groups continue to experience floods as part of their everyday realities to life on the coast. 


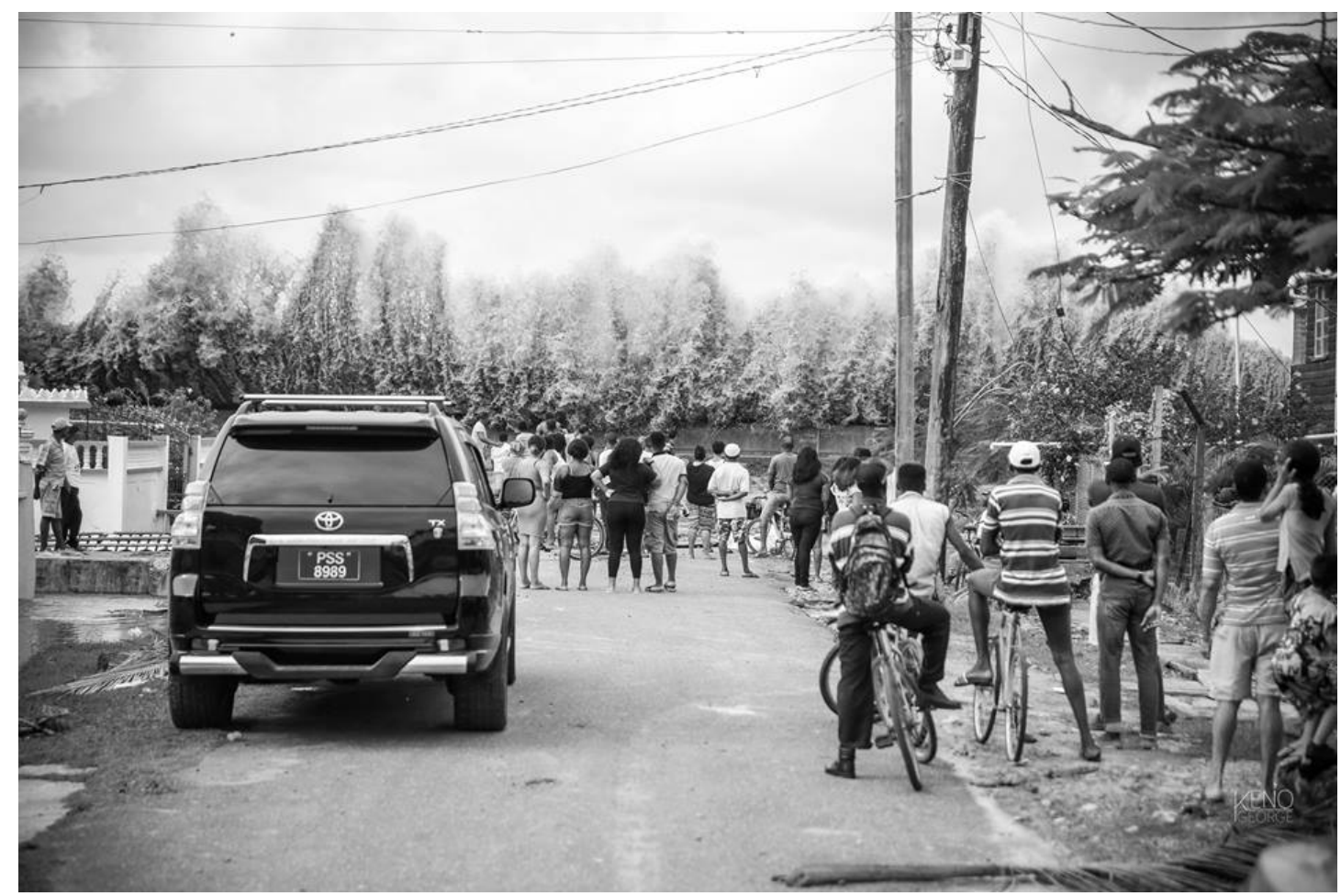

Plate 9 - Ocean swells overtopping the sea wall, West Coast Demerara, March 2, 2018. Photo courtesy of KeNo George Photography

Though the extent of the overtopping and inability of the existing infrastructure to handle it was shocking to some along the coast, $\mathrm{BD}$ told me months prior that it was only a matter of time before something so severe occurred. When talking to other WCD residents, including those who would not allow me to record our conversations, several expressed that floods were not an issue. The regular overflowing of canals did not in themselves constitute flooding for these residents because floods meant a rupture in everyday life which cannot happen when something is a regular occurrence — you have to live through them. The overtopping this time represented a major rupture in everyday life, displacing people from their homes and closing schools and businesses as the heavily 
silted water made its way through village streets. The everyday experiences with floods, even minor "non-floods," was not necessarily always the case, however.

Marvin, a long-time resident of the West Coast and staunch PNC supporter told me how, as a child, he used to be able to walk for several hundred yards beyond the sea wall at low tide, an area that he claims is now never exposed. He was unsure if this was caused by erosion or some other process, but he did note that the frequency of floods seemed to have increased with this change. The original sea wall constructed when his village was still a sugar plantation, he claimed, could be found further north and land that once was used for sugar and cattle by planters and villagers alike is now part of the sea, the current sea wall being built as a replacement by the Dutch in the 1970s when overtopping became too frequent ${ }^{92}$. Though generally critical of foreign intervention, in sharp contrast to Mary and BD's sentiments that Guyanese have the knowledge and ability to solve problems of coastal flooding, Marvin felt as though the British and the Dutch owed a responsibility to Guyana to help them address their experiences with flooding as they were ultimately responsible for designing, building, and making necessary the infrastructure in place today.

With an international shift away from sea walls toward "green infrastructure" and particularly with recent Dutch projects means to "design with nature," what might this intervention look like? As BD and others noted, mangroves had already been a part of the solution to Guyana's flood problems but had little to no real effect in the WCD region.

92 I have been unable to independently verify this, but I have no reason to think that this is not the case. 
Tamsin, a forestry student at the University of Guyana was convinced that proper mangrove management was the future and the government seems to agree, focusing its sea level rise mitigation efforts on the Guyana Mangrove Restoration Project, which has seen significant success in reducing the incidences of floods along the East Coast Demerara region, from Beterverwagting to Mahaica, where mangrove stands are well established.

\section{Conclusion: River and Sea Defense in an Era of Sea Level Rise}

While there are indications that the threat of coastal flooding has decreased with recent flood control measures, less clear is how the government plans to mitigate the impacts of sea level rise. Though a frequent topic of conversation, sea level rise largely appears as a nebulous entity in Guyana, both an existing threat to the country's safety and sovereignty but something altogether foreign and distant enough that other concerns take precedence. As a country that has, in its entire modern history, existed below sea level, what impacts will rising seas actually have? The majority of the inhabited coast is already defended by sea walls in various states of repair with sections from Kitty and stretching out along the East Coast Demerara region already extended to prevent overtopping from increasingly rough high tides. As discussed in Chapter 1, the Guiana Current batters the coast with processes of rapid accretion and erosion that undermines the wall's support system and constantly threatens collapse. This same current and the geophysical processes with it, however, created and supported dense mangrove forests that were removed to expedite colonial development, leaving much of the coast vulnerable. To address these shortcomings, since the late-1990s, the Guyanese government has been 
working on planting and restoring mangrove stands along the coast, solidifying these efforts with the creation of the Guyana Mangrove Restoration Project in 2010, but with mixed success in terms of their longevity. During a public presentation in November 2017 I was asked my opinion on mangroves as a way of protecting the coast and the flooding in March 2018 certainly sparked interest in the topic amongst some Guyanese on Facebook, but does the government's current focus on mangroves provide meaningful solutions to the problem of coastal vulnerability? What can an investigation of Guyana's mangroves tell us about the relationship between humans and non-humans on the coast and in particular how non-humans become actors in the construction of racial geographies and processes of capital accumulation that have dominated the history of the coast?

As biological entities, mangroves have a proclivity for reproduction. They move and spread, taking over new lands while ceding others to the erosive actions of the brackish and salt water that they call home. They create dense networks of impenetrable roots, create habitats for a vast array of living things, and cement in place the muds and silts that form the basis of shorelines. These processes are referred to collectively as "colonialism," a name obviously borrowed from the human actions that similarly create and cement networks of relations. In the coastal zones in which they are most prominent, mangrove forests are also entangled in networks of human relations and structures of power, their ability to move shaped and limited by borders of sea walls, groynes, and subsurface structures meant to slow or outright prevent their freedom to flourish (cf. Ogden 2011). They constitute an important part of coastal landscapes that "are assemblages constituted by humans and nonhumans, material and semiotic processes, 
histories both real and partially remembered" and in which "a broader politics of nature works to constrain the entanglement's [of mangrove's roots and human and non-human actors] freedom of movement and connectivity" (Ogden 2011, 35). In Guyana, engineered structures and the racial geographies established under colonialism and enforced by postcolonial politics are equally important components of these landscapes. Thus, if mangroves are meant to protect the coast, the ways in which they do so are codetermined by the existence of this multitude of historical and contemporary actors.

Billboards along the public road that lines Guyana's coast vaguely ask Guyanese to "protect" mangroves (see Plate 10), but not to let them live and flourish for their own sake. This is part of what Sarah Vaughn (2017) has argued are the "epistemic politics of mangrove restoration," where GMRP scientists and the local community negotiate the relationship between climate change adaptation strategies, technoscientific knowledge on coastal engineering, and the economic needs and desires of local communities. But in these instances, to "protect" mangroves is to render and maintain them as useful objects for human and particularly capitalist endeavors. Mangrove protection seeks to preserve not just the plants, but also - and primarily - the coastal world behind the plants without challenging the basic assumptions about what in that world might need to change in order to actually address individual vulnerabilities. In as far as mangroves are denied a right to exist without the protection of the state and human populations, we might ask why such protections are necessary. Mangroves once dominated Guyana's coast. Their decomposed remains mixed with the mud and silt that they had accumulated to produce the pegasse soils that supported colonial efforts, but their broken limbs battered coastlines and accelerated coastal erosion, turning them into new extensions for the sea. In their 
freedom, mangroves created and destroyed land, but under colonial and postcolonial control they are denied that right - either through their outright removal or through the strict discourses of protection that seek to limit their growth and spread to that which is useful. Their existence is relegated to the protection of capitalist interests. Without their engineered enclosures, they often don't seem interested in developing into the dense forests necessary for such interests any longer. They would rather wither away. In this way, we might see mangrove death as resistance to capitalism. The stiff structures, the accounting, and the limited possibilities for free movement that are required to maintain Guyana's capitalist system are antithetical to the very being of mangroves, so they die.

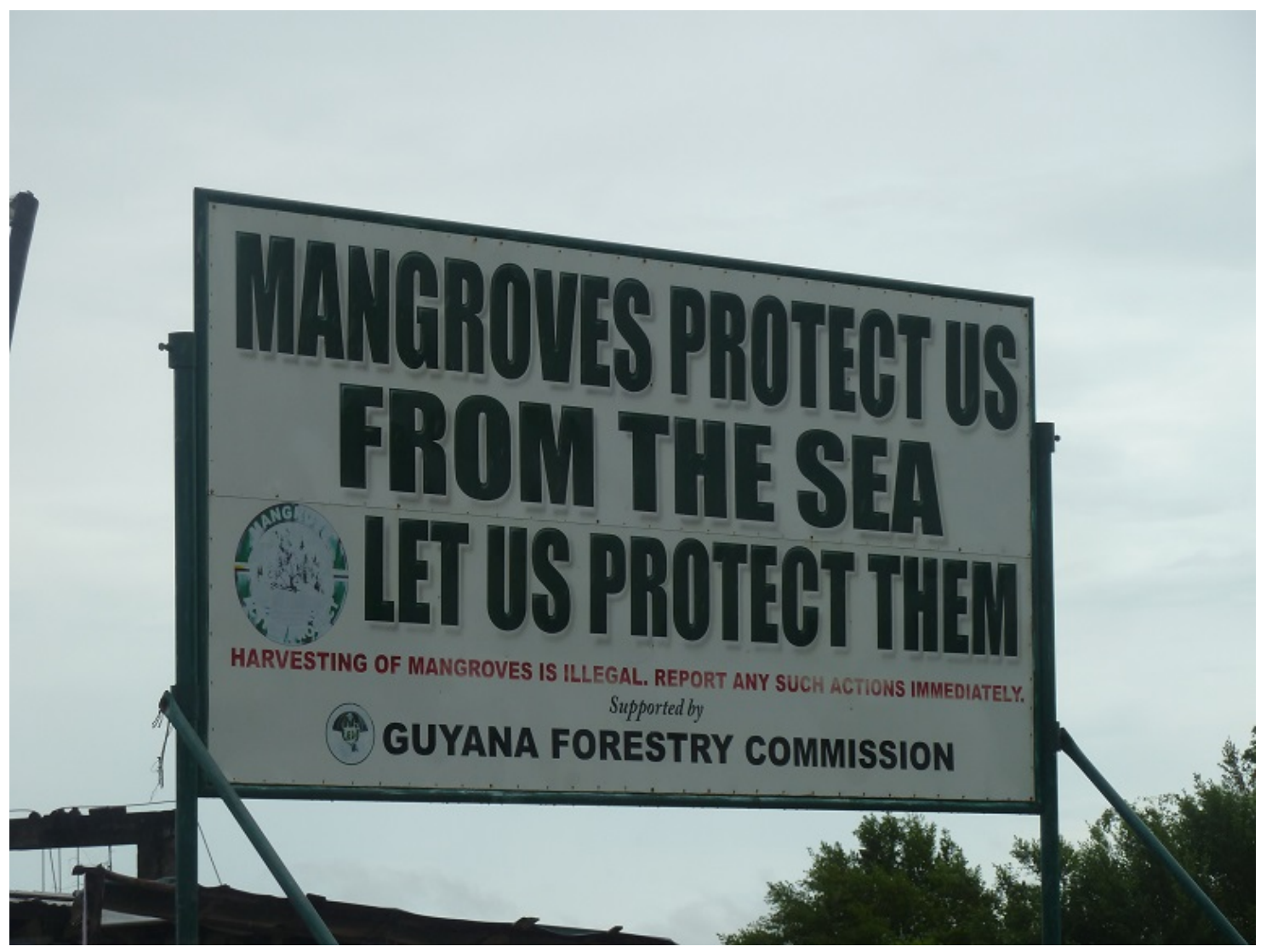

Plate 10 - Billboard by the Guyana Forestry Commission advocating for mangrove protection. 
While mangroves would undoubtedly work to reduce the actual flood events, they do nothing to address the things that make people vulnerable to them. As residents of Den Amstel told me, it's not the floods themselves that pose a threat but their ability to disrupt life. It is this disruption that produces precarity and leads to a lack of socioecological resilience. The inability of people to get by — much less flourish — with the everexisting threat of flooding has been the most frequent problem for Guyanese regardless of race. This was likewise the case in 2005 and 2006 which saw people concreting their yards in order to avoid missing work and school, functions which are required to feed and house themselves even in Guyana's mixed economy. The structuring factors of everyday life in Guyana, a life in which the majority of the population relies precariously on daily wage labor to meet their basic needs, remain in place even if mangroves succeed in stopping the water from penetrating the neighborhoods.

This should not be read as a criticism of the efforts of the Guyana Mangrove Restoration Project. To the contrary, the fact that they have successfully overcome ecological barriers to mangrove growth should be applauded, but at the same time, ignoring the ways in which mangroves interact with social and economic processes means that their effects in reducing flood vulnerability will be limited. Flooding may still occur from the river swells or from overflowing or conservancy collapse. Mangroves may likewise present a false sense of security along the coast. During my first visit to the GMRP offices in 2015, I was given a tour of a particularly vibrant mangrove stand in Beterverwagting. Although most of the village sea walls are backed by a ditch to catch any overtopped water and drain it to a nearby koker, the success of the mangrove project 
has encouraged residents to fill in that ditch and build houses adjacent to the sea wall. Meanwhile, the mangroves themselves have become dumping grounds for those same residents who rely on them for coastal protection.

The legal frameworks for flood control, the colonial racial geographies of the coast, and the emergence of a racially bifurcated political system shape flood vulnerability in complex ways. They rely on operations of power that extend beyond just the words of the party leaders but which exist in the infrastructural logic that remains an important part of coastal life. There is likewise a broader system at player in which the diffuse power of the country's political economy and continued reliance on coastal agricultural production solidify colonial presence (see Stoler 2016). Building socioecological resilience requires removing the systems which produce precarity for the coastal population. A system in which the day-to-day activities or people's basic ability to survive are not threatened by minor coastal flooding is an apparent necessity as this would provide an opportunity for the dynamism socioecological resilience requires (see Angeler et al. 2016). Thus, if there is going to be a solution to coastal flooding in the postcolonial period, it should not repeat the mistakes of the colonial, ignoring the country's racial geographies and political economic precarity of substantial portions of the population and instead address the conditions that make people vulnerable in the first place. This is reflected in the final, concluding chapter. 


\section{CONCLUSION - COLONIAL RUINS AND THE CONSTRUCTION OF FLOOD VULNERABILITY: LESSONS FROM AND FOR GUYANA}

"The only way to understand something in the past is to understand that it too used to be a now. It's to feel the faint breath of the air in which the human beings of yesterday lived

their lives. [...] The current disaster is like a monstrous accumulation of all the deferrals of the past, to which are added those of each day and each moment, in a continuous time slide. But life is always decided now, and now, and now." - The Invisible Committee, Now $(2017,7)$.

"Men make their own history, but they do not make it as they please; they do not make it under self-selected circumstances, but under circumstances existing already, given and transmitted from the past. The tradition of all dead generations weighs like a nightmare on the brains of the living. And just as they seem to be occupied with revolutionizing themselves and things, creating something that did not exist before, precisely in such epochs of revolutionary crisis they anxiously conjure up the spirits of the past to their service, borrowing from them names, battle slogans, and costumes in order to present this new scene in world history in time-honored disguise and borrowed language." Karl Marx, The Eighteenth Brumaire of Louis Bonaparte (1852/1999, 5). 
The two quotes above highlight the general essence of flood control projects in Guyana, both their past and their presents. To summarize briefly, the current situation i.e. a constant threat of inundation and the catastrophic prospect of sea level rise - would not be possible without the displacement of indigenous lives and livelihoods and the subsequent establishment of a new colonial order. They could not exist as they do without the brutality of enslaved labor building evermore canals and - after the abolition of slavery - without the use of floods themselves to reinvigorate and maintain the economic structures of colonialism that made such an arrangement worthwhile for the Europeans who profited so heavily from it. The needs of capitalistic expansion beyond sugar and into the empty spaces of the colonial landscape likewise set forth new conditions in which people's lives would and continue to face the threat of inundation while at the same time dividing the population along racial lines, reducing social cohesion and creating new means through which vulnerabilities to flooding can be enacted (cf. Pelling 1999). The response has been, to a greater or lesser extent, more walls, more pumps, more canals, more infrastructure - a solution both embedded within the logic of the past and cognizant of the infrastructural realities of the present. Even ecological restoration in the form of mangrove regrowth is done primarily for the protection of humans and the capitalist world in which they inhabit and not for the sake of the mangroves or their right to flourish as an equal inhabitant of the coast, but the problems facing the coastal plain remain. An extracted headline from the January $24^{\text {th }}$, 1935 edition of The Daily Argosy claiming "Stagnation After a Century, Colony Either Flooded or Burnt Out [...] Irrigation and Drainage the Road to Prosperity [...] Governor 
Says Development Should Be Seriously Considered" (see Figure 6) could easily be read in one of the major newspapers of the country today.

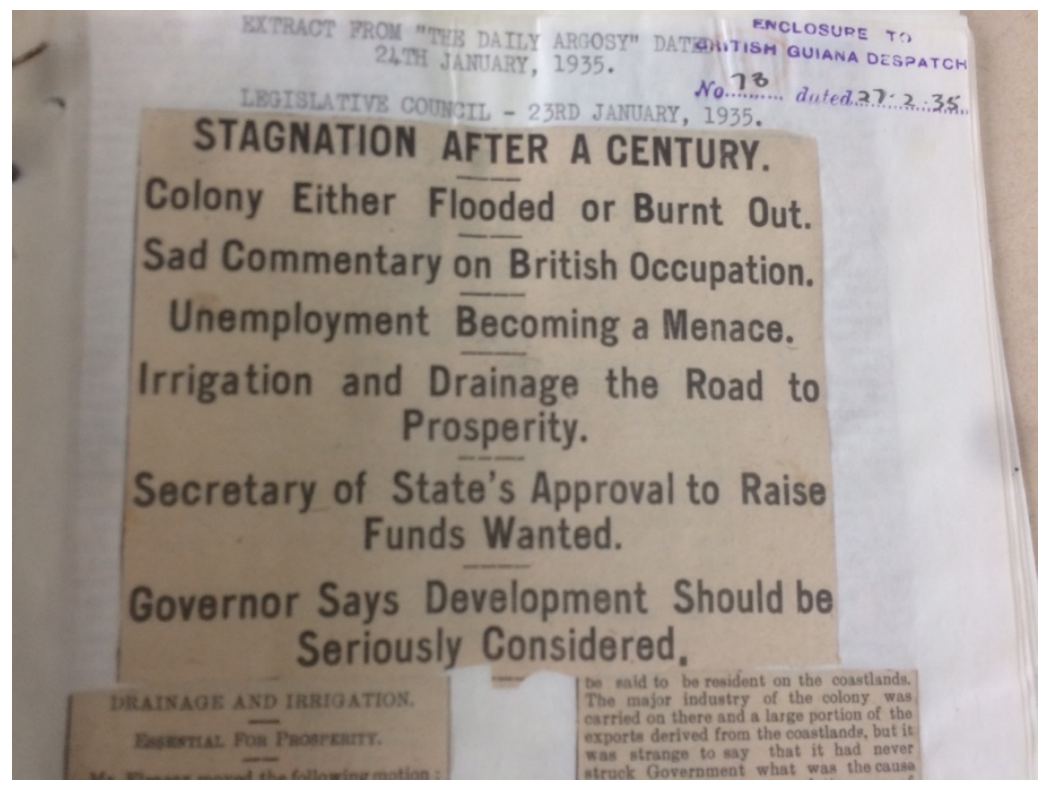

Figure 6 - Extract from the January 24th, 1935 The Daily Argosy. Source: CO 111/727/1, The National Archives, UK

The past thus acts as a source for cumulative, intergenerational trauma in coastal areas around the world, but particularly in Guyana and other postcolonial states where flooding and flood vulnerability become intertwined with the racial legacies of the colonial encounter. It not only structures the lives of individuals in the present by limiting the range of human ideas and actions (imagining Guyana without a coast, however real a threat, is not something most people are comfortable with), but it also continues to inscribe on the coast the only forms of action which are seen to be legitimate: those that rely on and recreate colonial engineering practices. Solutions to problems structured by the past are contingent. They draw on a significant amount of information but, like the 
French armies of Marx's time, solutions to present environmental crises offer nothing really new, instead putting on the uniforms of the past in an attempt to address the problems of the present. In this way a continued focus on infrastructure and likewise on maintaining the political economic status quo without considering other possibilities for life continues to produce conditions of precarity.

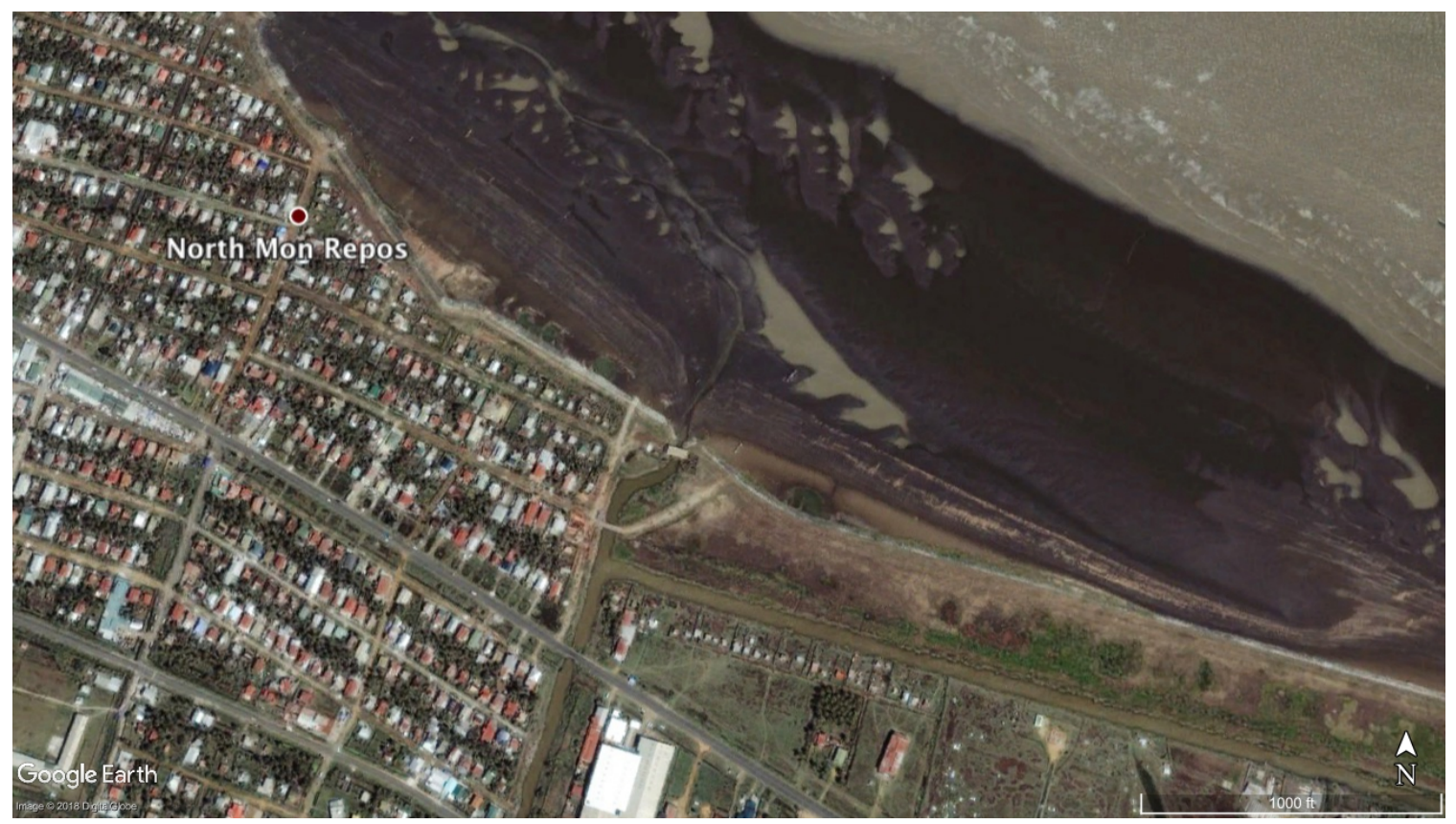

Figure 7 - The Mon Repos Coast, 2002. Source: Google Earth 


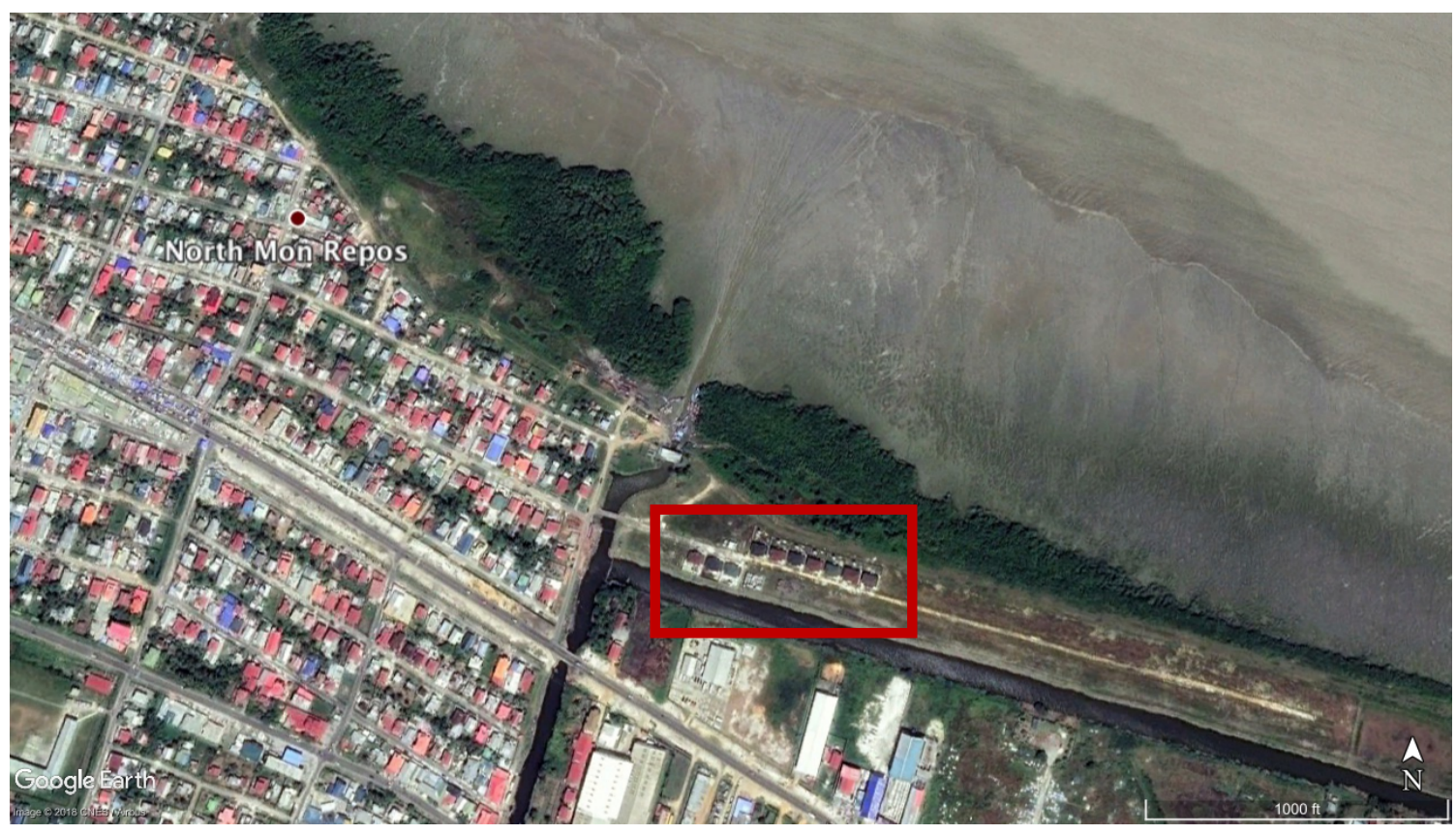

Figure 8-The Mon Repos Coast, 2017. New housing highlighted. Source: Google Earth.

In Guyana, this is most obvious in the East Coast Demerara communities of Mon Repos and Beterverwagting, where the success of the Guyana Mangrove Restoration Project has encouraged new settlement in what were once lands designated as important parts of flood control infrastructure. Figure 7 and Figure 8 highlight this development in the case of Mon Repos. Figure 7 shows a section of the coast in 2002. With limited mangrove protection, the area to the east of the koker was reserved for water control in the event of overtopping. Water coming over the sea wall would fall safely into a canal where it could be stored until tides returned to a low enough level that the koker could be opened and the water drained back out to sea. The addition or re-establishment of mangroves in the area changes the coastal dynamics. Mangroves break the waves far ahead of the shore, rapidly reducing large ocean swells to little more than a ripple. In the 
process, sediment carried in those swells is deposited at the rear of the mangrove stand, creating a new natural levee and eventually extending the coastline out to the sea (Chapter 1; see also Othman 1991). With mangroves reducing the wave action on the coast and thus also eliminating experiences of overtopping, people have begun to build houses ${ }^{93}$ between the sea wall and the canal (Figure 8), creating a new proximal exposure to sea water in the event that the mangrove forests die or otherwise give way to the sea.

This reflects a situation in which decisions about flooding are still being made in a way that only considers the "now" but without thinking about the potential futures being created in the process. While the material conditions will differ significantly, the general problem of structuring future vulnerabilities through the creation of presents which don't consider those futures remain. Solutions for "now" must therefore also have a variety of potential futures in mind. The financial and legislative mechanisms over flood control enacted by colonial and postcolonial regimes served as a central means by which the government could regulate the lives and livelihoods of Guyana's population. These projects corresponded to the political, economic, and racial dynamics of the country through authoritarianisms rooted in both the hegemony of the plantocracy in the colonial period and in the racially-driven dictatorship of Forbes Burnham and the PNC. Beyond strict electoral control (through the refusal of adult suffrage under colonialism and blatant election rigging under Burnham), these regimes were able to use flood control and its

\footnotetext{
${ }^{93}$ I was not able to find out who owns these or other similarly built houses. One of my informants told me that they belong mostly to American-based Guyanese from the villages who want a more modern house to stay in when they visit Guyana, but I could not verify this.
} 
related infrastructural commitments to maintain and grow their economic and political power. Equally important to these projects were the tax burdens imposed on AfroGuyanese populations during colonial rule and the willful neglect of flood control infrastructure in both the colonial and postcolonial era as a means of increasing the vulnerability of populations to ensure they could not actively resist the authoritarian state. Additionally, in the former case, it could be argued that taxation itself served as a separate act of governance separate from its role in funding the colony by making colonized populations governable (Bush and Maltby 2004). During the colonial period, new means of legislating and funding flood control infrastructure insured that alternatives would not develop and that the laboring population would remain reliant on the plantation system for its survival (see also Young 1958). In the postcolonial period, infrastructural neglect was used to economically disenfranchise opposition groups who would otherwise have threatened Burnham's authoritarian regime. In all cases, the concern was the maintenance of the current regime and its multitude of forms.

In plain terms, creating infrastructures for flooding "now" is going to continue to have long-lasting impacts on both people and the environment. This is because, as I have argued here and has been argued by others, infrastructure serves a mediating role in everyday life. It "has become a medium of information. The information resides in invisible, powerful activities that determine how objects and content are organized and circulated" (Easterling 2014, 13). In Guyana, infrastructure created to deal only with immediate problems - of colonial expansion (Chapter 1), of colonial protection (Chapter 2 and Chapter 3), and of regime survival (Chapter 4, cf. Hintzen 1989) - has worked to produce and reinforce a racial geography in which three different colonized populations 
(Amerindian/indigenous, Afro-Guyanese, and Indo-Guyanese) occupy discrete positions in the country geographically, economically, and politically. Likewise, it is not necessarily possible to know what properties of a particular infrastructural response will take. They alter and become a part of complex socionatural systems and only gain meaning through their use (and abuse.) Thus, rather than a teleological history in which the manipulation of flood control infrastructures for various ends is inevitable, the history of flood control is one in which various individuals and groups wield power to respond to a variety of spatially and temporally specific concerns stemming from and occurring within a broader political, economic, social, geophysical, and ecological system which they can never fully understand.

Beyond this, however, current flood control regimes and the ideologies which conjure them have produced a long-lasting and systematic precarity with which the average Guyanese person must contend on a daily basis. Isabell Lorey $(2015,13)$ has brilliantly explained how experiences with precarity can lend themselves to unique forms of governance, arguing that "[u]nderstanding precarization as governmental makes it possible to problematize the complex interactions between an instrument of governing and the conditions of economic exploitation and modes of subjectivation." Lorey situates her argument within neoliberalism and suggests that government by and through precarity is unique to modern, neoliberal forms of governmentality. However, through a genealogy of flood control I have shown in this dissertation how the continued environmental threat of flooding and the proposed solutions in Guyana have created a situation in which flood control infrastructure becomes itself an "instrument of governing" with its own internal logic and structure (i.e. its own mentalité) that can be 
understood as working on the basic threat and reality of precarity. Rather than a means for protecting the coastal region from the threat of floods, flood control projects have been designed in such a way to protect the political, economic, and social stability of the coast including its agricultural industries and its racial hierarchies not just from natural hazards, but also from the ever-present threat posed by the potential resistance of the country's exploited classes. It does this specifically through the creation and enabling of particular environmental forms that produce precarity and then offering infrastructural solutions to them, producing new racial and cultural geographies in the process. This suggests that the history of such modes of governing extend much further into history than Lorey imagines. Lorey, in a way, falls into a trap noted by the architect Keller Easterling $(2014,22)$ when she states "[w]ell-rehearsed theories like those related to Capital or neoliberalism continue to send us to the same places to search for dangers while other concentrations of authoritarian power escape scrutiny." The historical experience of coastal flooding in Guyana thus shows that many of the logics of coastal engineering are not only embedded within but are also extensions of the colonial project itself. They act as extensions of colonialism into the present and provide an easy-to-use framework for deciding how to deal with problems with which a postcolonial country has a long history. But might there be alternatives?

The idea that floods are only floods when they disrupt daily life is worth considering. In my conversations with the people who expressed these ideas I was initially taken aback. One man I spoke to, Marcus, went as far as to say he hadn't experienced a flood in recent memory despite the fact that his neighbor, who did not wish to be recorded, complained about a flood that happened a year prior. Was the three inches 
of standing water in the alley leading to my apartment not a flood? For, Earl, the civil engineer I spoke to who empoldered his own yard it would have been. He shared with me several pictures showing what some would consider to be lesser events, but which caused serious problems for him and his neighbors despite living within the normally welldrained capital city of Georgetown (see Plate 11). His response, to literally extend the logic of colonial engineering onto his personal property, is certainly not scalable. The average Guyanese person has neither the time nor the means to maintain such a complicated system. But if we take seriously the idea that solutions for flooding may already exist in the form of the everyday actions of individuals there might be some valuable lessons to be learned when it comes to understanding both contributions to precarity and the building of resilient coastal regions.

During my fieldwork I befriended a number of individuals of the homeless and squatter population living in the Tiger Bay area of Georgetown. One of these men, James, an older man originally from Bartica, told me how he and a few others in the area don't trust the government to maintain even the basic aspects of flood control infrastructure. He and other squatters living in Tiger Bay collect trash from the drains and attempt to keep water flowing so that they will not flood. James felt that if he and a few others from the country's most vulnerable population could have an effect on local flooding, then the population as a whole could have a large impact if they just took better care of the places they lived and worked. For him and the others it was a practical matter: if the area was flooded no one would go to the shops and restaurants and there would be no one to give them money. James was skeptical as to whether or not the shop owners or government 
would be willing to do the work but felt that if he could carry the burden of making his neighborhood a more inhabitable space so could others who were better off.

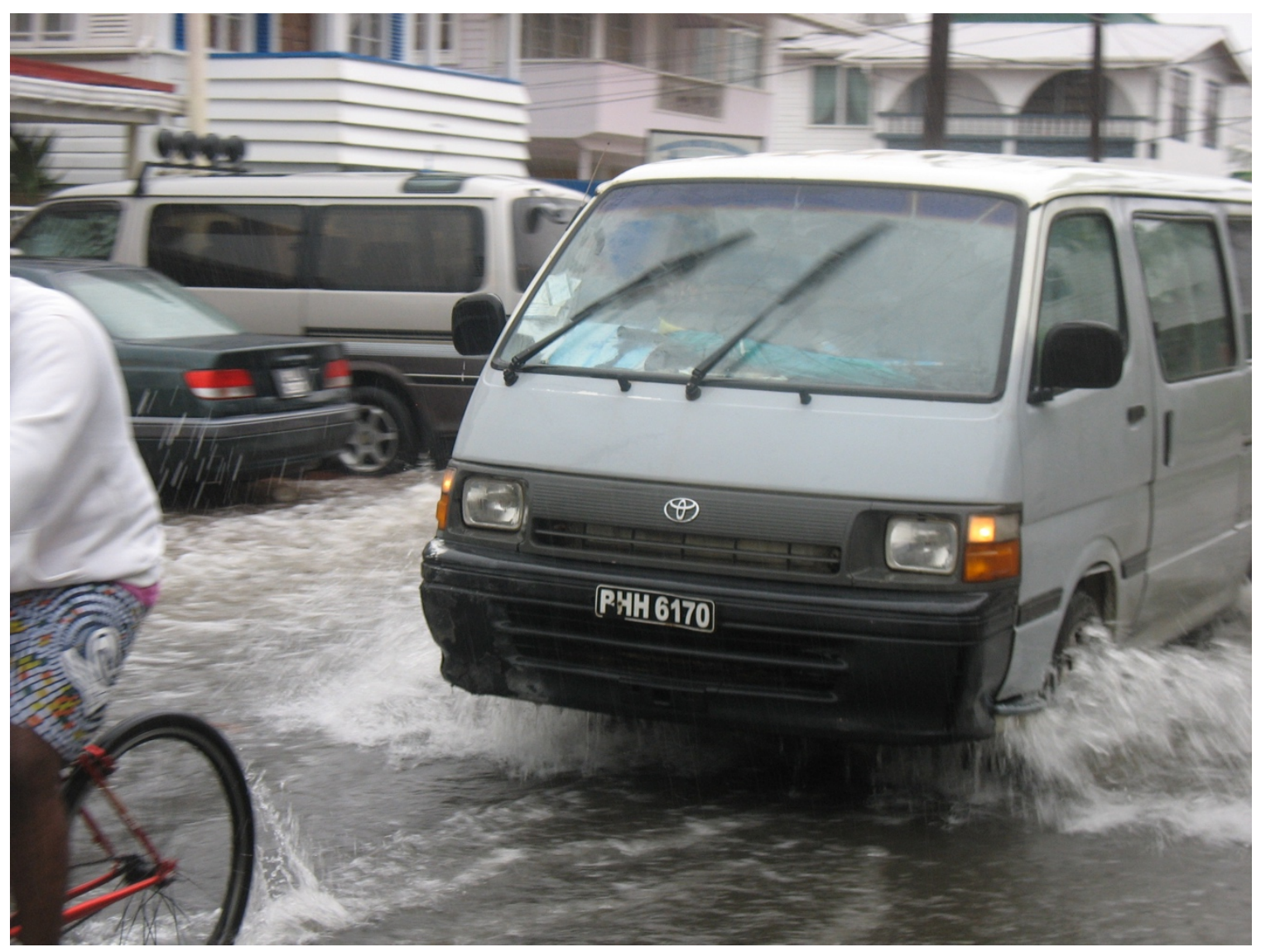

Plate 11 - Flooding on Quamina Street, Georgetown. November 27, 2013. Photo Courtesy of "Earl"

For James and a few of the others, cleaning drains was a collective action. It was something done in order to improve the conditions not just for themselves but also for others in the area. This sort of attitude has precedence among squatter communities with Pelling (1999) noting that it was the collective action of squatters that largely prevented 
their communities from flooding in the $1990 \mathrm{~s}^{94}$. I want to suggest that this sort of collective responsibility might form one part of a solution to coastal flood threats. While the government does have a responsibility to act on the behalf of people and prevent flooding, too often those actions are either not enough on their own or are done in a way that is meant to make it seem like they are doing more than they really are (as was the case in the examples in Chapter 4).

A second component of this is the decolonization of the coast. This raises uncomfortable questions about land and property rights, about the role of the diaspora, and about who is responsible for colonization in the first place that I am not qualified to answer (because the answers must come from Guyanese themselves.) But, the continued reliance on colonial structures and systems of decision-making work to reproduce the disconnected and at times abstract nature of colonial governance. Experimenting with indigenous forms of coastal life (drawing from Amerindian, African, and Indian experiences) may offer new ways to address these questions but requires that erasure of Amerindian communities from the coast no longer be part of Guyana's story. Based on conversations I had with parents and school teachers, Guyanese children are still taught that the coast was a terra nulius ready for settlement. Recognizing that colonial settlement was not done by the colonizers but that it was done by other colonized groups who were given control of the postcolonial state in some ways works to challenge the legitimacy of that state.

94 These areas have since be formalized and I was told both that those types of collective actions no longer happen and that they happen but not on the same scale. 
More generally, this disrupts what has often been seen as a clean binary between the colonizers and the colonized. As Walter Rodney (1972) and others argued in the case of Tanzania, decolonization can take a number of forms but when it is only legislative in nature it does not necessarily constitute decolonization. This does not mean that all those on the land must leave, that African and Indian Guyanese people must relinquish all rights they can claim to the land, but that those rights might not be as exclusive as they appear and that this might be a good thing. By beginning to undo the structures (and infrastructures) of colonialism new possibilities for coastal life may emerge, not only in Guyana but elsewhere. The roots of this thinking are showing in the form of Mary, BD, and James, but can be quickly cut down by what can only be described as colonial nostalgia $^{95}$ - the idea that times were better during the colonial period and thus they should be emulated rather than rejected. Alternatively, there is an emergent desire for renewed colonial resistance. Mary is a vocal advocate for this, but it's taking more institutionalized forms as well.

In March of 2016 the villages of Beterverwagting and Triumph voted against both major parties, electing a community group called the ' $8^{\text {th }}$ of May Movement,' so-named because on May 8, 1839, emancipated slaves loaded 52,000 Dutch Guilders into a wheel barrow to purchase the land that would become the villages (see Young 1955). Their goal was to return to the forms of self-government imagined by their village founders. Leyland

${ }^{95}$ Colonial nostalgia is typically used to refer to metropolitan tourists visiting the colonies, but in this case I'm using it to refer to Guyanese themselves who express a desire for a return (at least partially) to some aspects of colonial governance specifically because they were colonial. 
Harcourt, leader of the movement, told the Guyana Chronicle "We decided to go this as a village movement, because if we had belonged to a party we might have been asked to toe the party line, even if it is not in the best interest of the community. [...] And so we believed that, as a community group, we are in a better position to call the shots for the development of our community" (“Local gov't elections..." 2016). Whether they follow in the footsteps of their forbearers and develop alternatives has yet to be seen, but the idea that it is communities themselves who are best situated to determine their futures is vital to building coastal community resilience. Beyond more or better engineered systems there is a dire need to address the social causes of vulnerability, that which makes it possible for floods to disrupt daily life and not be simple annoyances. No one knows better than those affected by them what the actual causes of disruption were and likewise what they need to better handle and respond to future events, allowing them to address the now and the future without continuing to replay the engineering logic of the past. 


\section{REFERENCES}

Adamson, A. 1972. Sugar without Slaves: The Political Economy of British Guiana, 1838-1904. New Haven, CT: Yale University Press.

Aldrich, D.P. 2012. Building Resilience: Social Capital in Post-Disaster Recovery. Chicago: University of Chicago Press.

Allison, M.A, M.T Lee, A.S Ogston, and R.C Aller. 2000. Origin of Amazon Mudbanks along the Northeastern Coast of South America. Marine Geology 163: 241-56. DOI:10.1016/S0025-3227(99)00120-6.

Anderson, B. 2015. "What kind of thing is resilience?" Politics 35(1): 60-66.

Angeler, David G., Craig R. Allen, Ahjond S. Garmestani, Lance H. Gunderson, and Igor Linkov. 2016. "Panarchy Use in Environmental Science for Risk and Resilience Planning." Environment Systems and Decisions 36(3):225-28.

Anthony, E.J., A. Gardel, N. Gratiot, C. Proisy, M.A. Allison, F. Dolique, and F. Fromard. 2010. The Amazon-Influenced Muddy Coast of South America: A Review of Mud-Bank-Shoreline Interactions. Earth-Science Reviews 103 (3-4): 99-121. doi:10.1016/j.earscirev.2010.09.008.

Aradau, C. 2014. "The Promise of Security: Resilience, Surprise, and Epistemic Politics." Resilience 2(2): 73-87.

Aradau, C. and R. Van Munster. 2011. Politics of Catastrophe: Genealogies of the Unknown. New York: Routledge.

Barnes, J. 2017. "States of Maintenance: Power, Politics, and Egypt's Irrigation Infrastructure." Environment and Planning D: Society and Space 35 (1): 146-64. doi:10.1177/0263775816655161.

Bartels, D. 1977. "Class Conflict and Racist Ideology in the Formation of Modern Guyanese Society." Canadian Review of Sociology/Revue Canadienne de Sociologie 14(4):396-405.

Bevir, M. 2008. What is Genealogy? Journal of the Philosophy of History 2: 263-275. DOI: $10.1163 / 187226308 X 335958$

Bey, H. 2003. T.A.Z: The Temporary Autonomous Zone, Ontological Anarchy, Poetic Terrorism. Brooklyn: Autonomedia. 
Biggs, R., M. Schüller, and M.L. Schoon. 2015. Principles for Building Resilience: Sustaining Ecosystem Services in Social-ecological Systems. Cambridge, UK: Cambridge University Press

Blaikie, P.. 1985. The Political Economy of Soil Erosion in Developing Countries. London: Longmans Development Studies.

Blaikie, P. and H. Brookfield. 1987. Land Degradation and Society. New York and London: Methuen.

Bogost, I. 2015. "The Aesthetics of Philosophical Carpentry." In The Nonhuman Turn, edited by Richard Grusin, 81-100. Minneapolis: University of Minnesota Press.

Boonstra, W.J. 2016. "Conceptualizating power to study social-ecological interactions." Ecology and Society 21(1): 21.

Bouwer, L.M., P. Bubeck, and J.C. J. H. Aerts. 2010. "Changes in Future Flood Risk due to Climate and Development in a Dutch Polder Area." Global Environmental Change 20(3):463-71.

Brahinsky, R., J. Sasser, and L-A. Minkoff-Zern. 2014. "Race, Space, and Nature: An Introduction and Critique." Antipode 46(5) 1135-1152.

Brand, F. 2009. "Critical Natural Capital Revisited: Ecological Resilience and Sustainable Development.” Ecological Economics 68(3): 605-612.

Brinkman, R., and L.J. Pons. 1968. Soil Survey Papers, No. 14. Wageningen, Netherlands Soil Survey Institute.

British Guiana. 1941. Administration Report of the Director of Agriculture for the Year 1940. Georgetown: The Argosy Company, Limited.

Brown, J. C. and M. Purcell. 2005. "There's nothing inherent about scale: political ecology, the local trap, and the politics of development in the Brazilian Amazon." Geoforum 36: 607-624.

Browne, S. 2006. Aid \& Influence: Do Donors Help or Hinder. London: Earthscan.

Bryant, R. 1997. "Beyond the Impasse: the power of political ecology in Third World environmental research." Area 29(1): 5-19.

Burnham, L.F.S. 1974. "Declaration of Sophia: Address by the Leader of the People's National Congress, Prime Minister Forbes Burnham, at a Special Party Congress to mark the $10^{\text {th }}$ Anniversary of the P.N.C in Government." http://lfsburnhamfoundation.org/cms.php?tl=Declaration\%20of\%20Sophia 
Bush, B. and J. Maltby. 2004. "Taxation in West Africa: transforming the colonial subject into the 'governable person." Critical Perspectives on Accounting 15(1): 5-34.

Canon, T. and D. Müller-Mahn. 2010. "Vulnerability, resilience and development discourses in context of climate change." Natural Hazards 55: 621-635.

Carney, J. 2001. Black Rice: The African Origins of Rice Cultivation in the Americas. Cambridge, MA: Harvard University Press.

Carrington, S.H.H. 2002. The Sugar Industry and the Abolition of the Slave Trade, 17751810. Gainesville, FL: University Press of Florida.

Carse, A. 2014. Beyond the Big Ditch: Politics, Ecology, and Infrastructure at the Panama Canal. Cambridge: MIT Press.

Castonguay, S. 2007. "The Production of Flood as Natural Catastrophe: Extreme Events and the Construction of Vulnerability in the Drainage Basin of the St. Francis River (Quebec), Mid-Nineteenth to Mid-Twentieth Century." Environmental History 12: 820-844.

Chabrol, D. 2018. "Emergency response teams deployed to flood-hit West Demerara villages; high tide breaks down seawall." Demerara Waves, March 2. http://demerarawaves.com/2018/03/02/emergency-response-teams-deployed-toflood-hit-west-demerara-villages-high-tide-breaks-down-seawall/

Chandler, D. 2014. Resilience: The Governance of Complexity. New York: Routledge.

Choi, Y.R.. 2014. "Modernization, Development and Underdevelopment: Reclamation of Korean Tidal Flats, 1950s-2000s." Ocean and Coastal Management 102(PB):426-36.

Collier, S.J. 2009. "Topologies of Power: Foucault's Analysis of Political Government beyond 'Governmentality."” Theory, Culture, \& Society 26(6): 78-108.

Collymore, C. 1984. Bitter Sugar and the Working People. Georgetown, Guyana: People's Progressive Party.

Cote, M. and A.J. Nightingale. 2012. "Resilience Thinking Meets Social Theory: Situating Social Change in Socio-ecological Systems (SES) Research." Progress in Human Geography 36(4): 475-489.

Cretney, R. 2014. "Resilience for Whom? Emerging Critical Geographies of SocioEcological Resilience." Geography Compass 8(9):627-40. 
Crow-miller, B. and M. Webber. 2017. "The (Re) Turn to Infrastructure for Water Management?” Water Alternatives 10(2):195-207.

Cudworth, E and S. Hobden. 2010. "Anarchy and Anarchism: Toward a Theory of Complex International Systems." Millennium: Journal of International Studies 39(2): 399-416.

D’Souza, R. 2006. "Water in British India: The Making of a 'Colonial Hydrology." History Compass 4 (4): 621-28. doi:10.1111/j.1478-0542.2006.00336.x.

DaCosta, M. 2007. Colonial Origins, Institutions and Economic Performance in the Caribbean: Guyana and Barbados. IMF Working Paper 43.

Daily Chronicle. 1886. "The Sea Defenses of the West Coast." 7 April. Georgetown, British Guiana.

Daily Chronicle. 1895. "Is the Long Sleep Nearly Over?" 16 May. Georgetown, British Guiana.

Daniel, J. R. K. 1988. "Sea Defence Strategies and Their Impact on a Coast Subject to a Cyclic Pattern of Erosion and Accretion." Ocean and Shoreline Management 11(2):159-75.

Daniel, J.R.K. 1989. The Chenier Plain Coastal System of Guyana. Marine Geology 90 (4): 283-87. doi:10.1016/0025-3227(89)90130-8.

Danns, G.K. 1997. "Race and Development in Plural Societies: The Case of Guyana." Caribbean Dialogue 3(2):32-41.

Dasgupta, S., B. Laplante, C. Meisner, D. Wheeler, and J. Yan. 2009. "The Impact of Sea Level Rise on Developing Countries: A Comparative Analysis." Climatic Change 93: 379-88. doi:10.1007/s10584-008-9499-5.

de Beer, J. and L. Bacchus. 1992. "Water-Balance Model of Two Conservancies in Guyana." Journal of Irrigation and Drainage ... 118(4):513-19.

de Leeuw, S. and S. Hunt. 2018. "Unsettling Decolonizing Geographies." Geography Compass doi:10.1111/gec3.12376

Deleuze, G. and F. Guattari. 1977. Anti-Oedipus: Capitalism and Schizophrenia. New York: Penguin Books.

Easterling, K. Extrastatecraft: The Power of Infrastructure Space. London: Verso Books. 
Edmundson, G. 1901. "The Dutch in Western Guiana." English Historical Review 16(64): 640-75.

Edwards, W. and K. Gibson. 1979. An Ethnohistory of Amerindians in Guyana. Ethnohistory 26(2): 161-175.

Escobar, A. 2008. Territories of Difference: Place, Movements, Life, Redes. Durham, N.C.: Duke University Press.

Essink, G.H.P. Oude. 2001. "Salt Water Intrusion in a Three-Dimensional Groundwater System in the Netherlands: A Numerical Study." Transport in Porous Media 43(1): 137-158.

Evans, B. and J. Reid. 2014. Resilient Life: The Art of Living Dangerously. Malden, MA: Polity Press.

Evans, C. and B.J. Meggars. 1960. Archaeological Investigations in British Guiana. Washington, D.C.: Government Printing Office.

Fabinyi, M., L. Evans, and S.J. Foale. 2014. "Social-ecological systems, social diversity, and power: insights from anthropology and political ecology." Ecology and Society 19(4): 28.

Farley, Rawle. 1954. "The Rise of the Peasantry in British Guiana." Social and Economic Studies 2(4):87-103.

Folke, C., S. Carpenter, T. Elmqvist, L. Gunderson, C.S. Holling, and B. Walker. 2002. "Resilience and Sustainable Development: Building Adaptive Capacity in a World of Transformations." Ambio 31(5): 437-440.

Foucault, M. 1982. "The Subject and Power." Critical Inquiry 8: 777-795.

Foucault, M. 2003. "Society Must be Defended": Lectures at the College de France, 1975-76. New York: Picador.

Gagné, K., and M.B. Rasmussen. 2016. "Introduction - An Amphibious Anthropology: The Production of Place at the Confluence of Land and Water." Anthropologica 58 (2): 135-49.

Galison, P. 2003. Einstein's Clocks, Poincaré's Maps: Empires of Time. New York: W. W. Norton.

Garnett, H. 1887a. "The Black People and the Floods." Daily Chronicle, 11 February. Georgetown, British Guiana. 
Garnett, H. 1887b. "The Planters and the Floods.” Daily Chronicle, 15 February. Georgetown, British Guiana.

Geertz, C. 1972. The Wet and the Dry: Traditional Irrigation in Bali and Morocco. Human Ecology 1 (1): 23-39.

Gersonius, B., R. Ashley, A. Pathirana, and C. Zevenbergen. 2013. Climate Change Uncertainty: Building Flexibility into Water and Flood Risk Infrastructure. Climatic Change 116 (2): 411-23.

Greenidge, C.B. 2001. Empowering a Peasantry in a Caribbean Context: The Case of Land Settlement Schemes in Guyana, 1865-1985. Mona, Jamaica: University of the West Indies Press.

Grove, K. 2014a. "Adaptation Machines and the Parasitic Politics of Life in Jamaican Disaster Resilience." Antipode 46 (3): 611-28.

Grove, K. 2014b. "Agency, Affect, and the Immunological Politics of Disaster Resilience." Environment and Planning D: Society and Space 32: 240-256.

Grove, K. 2018. Resilience. London and New York: Routledge.

Halliday, A. 1837. The Natural and Physical History of the Windward and Leeward Colonies. London: John William Parker.

Hammond, J.L. 2015. "The Anarchism of Occupy Wall Street." Science and Society 79(2): 288-313.

Handmer, J.W. and S.R. Dovers. 1996. “A Typology of Resilience: Rethinking Institutions for Sustainable Development." Organization and Environment 9(4): $482-511$

Hardy, R.D., R.A. Milligan, and N. Heynen. 2017. "Racial Coastal Formation: The Environmental Injustice of Colorblind Adaptation Planning for Sea-Level Rise." Geoforum 87: 62-72.

Harris, C.A. and J.A.J de Villiers. 1911. Storm Van's Gravesande: The Rise of British Guiana. London: The Hakluyt Society.

Hartman, C. and G.D. Squires. 2010. "Lessons from Katrina: Structural Racism as a Recipe for Disaster." Pp. 487-510 in Lessons from Katrina. Retrieved (http://www.racialequitytools.org/resourcefiles/lessonsfromkatrina.pdf).

Haynes, B.A. 2016. Plaisance: From Emancipation to Independence and Beyond. Georgetown, Guyana: F\&H Printing Establishment. 
Hayter, T. 1971. Aid as Imperialism. Baltimore, MD: Penguin Books.

Helmreich, S. 2011. "Nature/Culture/Seawater." American Anthropologist 113(1):13244.

Hill, K. 2015. Coastal Infrastructure: A Typology for the Next Century of Adaptation to Sea-Level Rise. Frontiers in Ecology and the Environment 13(9): 468-476.

Hintzen, P.C. 1989. The Costs of Regime Survival: Racial Mobilization, Elite Domination and Control of the State in Guyana and Trinidad. Berkeley: University of California Press.

Hintzen, P.C. 2004. "Creoleness and Nationalism in Guyanese Anticolonialism and Postcolonial Formation." Small Axe 15 (1): 106-22.

Hintzen, P.C. 2017. "Rethinking Identity, National Sovereignty, and the State: Reviewing Some Critical Contributions." Social Identities 1-9. doi:10.1080/13504630.2017.1314923.

Holling, C.S. 1973. "Resilience and Stability of Ecological Systems." Annual Review of Ecology and Systematics 4: 1-23.

Hughes, J.D. 2009. "Holland against the Sea." Capitalism, Nature, Socialism 20(3):96103.

Ingalls, M.L. and R.C. Stedman. 2016. "The power problematic: exploring the uncertain terrains of political ecology and the resilience framework." Ecology and Society 21(1): 6 .

International Bank for Reconstruction and Development. 1953. The Economic Development of British Guiana. Baltimore: The Johns Hopkins University Press.

Ioris, A.A.R. 2014. The Political Ecology of the State: The Basis and the Evolution of Environmental Statehood. London: Routledge.

Jackson, S. 2012. Creole Indigeneity: Between Myth and Nation in the Caribbean. Minneapolis: University of Minnesota Press.

Jenkins, E. 1871. The Coolie: His Rights and Wrongs. New York: George Routledge and Sons.

Khemraj, T. 2015. "The Colonial Origins of Guyana's Underdevelopment." Social and Economic Studies 4(3-4):151-85. 
Khemraj, T. 2016. The Political Economy of Guyana's Underdevelopment. The Review of Black Political Economy 43(3-4): 325-342 doi:10.1007/s12114-016-9239-4.

Kimmelman, M. 2017. "The Dutch Have Solutions to Rising Seas. The World Is Watching." June 15, New York Times. https://www.nytimes.com/interactive/2017/06/15/world/europe/climate-changerotterdam.html (accessed June 15, 2017)

Koch, A.M. 1991. "Poststructualism and the Epistemological Basis of Anarchism." Philosophy of the Social Sciences 23(3): 327-351.

Kooy, M. and K. Bakker. 2008. “Technologies of Government: Constituting Subjectivities, Spaces, and Infrastructures in Colonial and Contemporary Jakarta." International Journal of Urban and Regional Research 32(2):375-91.

Kropotkin, P. 1978. "What Geography Ought to Be.” Antipode 10-11(3-1): 6-15.

Lakhan, V.C.. 1994. "Planning and Development Experiences in the Coastal Zone of Guyana." Ocean \& Coastal Management 22(3):169-86.

Lave, R., M.W. Wilson, E.S. Barron, C. Biermann, M.A. Carey, C.S. Duvall, L. Johnson, et al. 2014. "Intervention: Critical Physical Geography." Canadian Geographer 58 (1): 1-10. doi:10.1111/cag.12061.

Li, Tanya Murray. 2007. The Will to Improve: Governmentality, Development, and the Practice of Politics. Durham, N.C.: Duke University Press.

"Local Gov't elections... BV - the community that has won the right to govern itself." 2016. Guyana Chronicle, March 26. http://guyanachronicle.com/2016/03/26/local-govt-elections-bv-the-communitythat-has-won-the-right-to-govern-itself

Look Lai, W. 2004. Indentured Labor, Caribbean Sugar: Chinese and Indian Migrants to the British West Indies, 1838-1918. Baltimore: Johns Hopkins University Press.

Lorey, I. 2015. States of Insecurity: Government of the Precarious. London: Verso Books.

MacLaughlin, J. 1986. "State-centered Social Science and the Anarchist Critique: Ideology in Political Geography." Antipode 18(1): 11-38.

Mahoney, J. 2010. Colonialism and Postcolonial Development: Spanish America in Comparative Perspective. Cambridge: Cambridge University Press. 
Mann, C.C. 2005. 1491: New Revelations of the Americas Before Columbus. New York: Alfred A. Knopf.

Marx, K. 1852/1999. The Eighteenth Brumaire of Louis Bonaparte. The Marxist Internet Archive. https://www.marxists.org/archive/marx/works/download/pdf/18thBrumaire.pdf

Marx, K. 1887. Capital: A Critique of Political Economy, Vol 1. London and New York: Penguin Books.

Mathews, T. 1966. The Three Guianas. Current History 51: 333-66.

May, T. 1994. The Philosophy of Poststructuralist Anarchism. University Park, PA: Penn State University Press.

McConnel, R.B. 1968. Planation Surfaces in Guyana. The Geographical Journal 134 (4): 506-20.

Meehan, K.M. 2014. Tool-Power: Water Infrastructure as Wellsprings of State Power. Geoforum 57: 215-24.

Menezes, M.N. 2010. The Portuguese in Guyana: A Study in Culture and Conflict. Caribbean Press.

Mintz, S. 1985. Sweetness and Power: The Place of Sugar in Modern History. New York: Viking-Penguin.

Mitchell, T. 2002. Rule of Experts: Egypt, Techno-Politics, Modernity. Berkeley: University of California Press.

Moore, B.L. 1975. "The Social Impact of Portuguese Immigration into Guiana after Emancipation.” Boletin de Estudios Latin Americanos y Del Caribe 19(19): 1-15

Moore, B.L. 1987. Race, power, and Social Segmentation in Colonial Society: Guyana After Slavery, 1838-1891. New York: Gordon and Breach Science Publishers.

Mullenite, J. 2015. Historical Repetition and Development Narratives in Guyana's Coastal Drainage and Irrigation System. Consilience: The Journal of Sustainable Development 14 (2): 126-39.

Mullenite, J. 2016. Resilience, Political Ecology, and Power: Convergences, Divergences, and the Potential for a Postanarchist Geographical Imagination. Geography Compass 10(9): 378-388. 
Mullenite, J. 2017. Can Climate Change Adaptation Be a Desirable Goal? Human Geography 10(2): 87-94.

Mullenite, J. Forthcoming. Infrastructure and Authoritarianism in the Land of Waters: A Genealogy of Flood Control in Guyana." Annals of the American Association of Geographers.

Naseer, M. 1978. "Black Bush Polder: A Case Study of Agricultural Change on a Land Settlement Scheme in Guyana.” PhD Dissertation, Economics, McGill University.

Neumann, B., A.T. Vafeidis, J. Zimmermann, and R.J. Nicholls. 2015. Future Coastal Population Growth and Exposure to Sea-Level Rise and Coastal Flooding - A Global Assessment. PLoS ONE 10 (3). doi:10.1371/journal.pone.0118571.

Neumann, R.P. 2005. Making Political Ecology. London and New York: Hodder Arnold.

Newman, S. 2001. From Bakunin to Lacan: Anti-authoritarianism and the Dislocation of Power. Lanham, MD: Lexington Books.

Noy, C. 2008. Sampling Knowledge: The Hermeneutics of Snowball Sampling in Qualitative Research. International Journal of Social Research Methodology 11 (4): $327-44$.

Ogden, L. 2011. Swamplife: People, Gators, and Mangroves Entangled in the Everglades. Minneapolis: University of Minnesota Press.

Olson, R.S. 2000. “Toward a Politics of Disaster: Losses, Values, Agendas, and Blame." International Journal of Mass Emergencies and Disasters 18(2): 265-287.

Oostindie, Gert. 2012. “'British Capital, Industry and Perserverance' versus Dutch 'Old School'? The Dutch Atlantic and the Takeover of Berbice, Demerara, and Essequibo, 1750-1815.” BMGN - Low Countries Historical Review 127(4):28-55.

Othman, M.A. 1991. "Value of Mangroves in Coastal Protection." Hydrobiologia 285: 277-282.

Pelling, M. 2011. Adaptation to Climate Change: From Resilience to Transformation. London and New York: Routledge.

Pelling, M. 1999. The Political Ecology of Flood Hazard in Urban Guyana. Geoforum 30: 249-61.

Pelling, M. 1998. "Participation, Social Capital and Vulnerability to Urban Flooding in Guyana." Journal of International Development 10(4):469-86. 
Pelling, M. 1997. "What Determines Vulnerability to Floods; A Case Study in Georgetown, Guyana.” Environment and Urbanization 9(1): 203-226.

Perreault, T. 2005. "State Restructuring and the Scale Politics of Rural Water Governance in Bolivia." Environment and Planning A 37(2):263-84.

Peterson, G. 2000. "Political Ecology and Ecological Resilience: An Integration of Human and Ecological Dynamics.” Ecological Economics 35: 323-336.

Premdas, R.R. 1974. "The Rise of the First Mass-Based Multi-Racial Party in Guyana." Caribbean Quarterly 20(3/4): 5-20.

Pritchard, S.B. 2011. Confluence: The Nature of Technology and the Remaking of the Rhone. Cambridge, MA: Harvard University Press.

Pritchard, S.B. 2012. From Hydroimperialism to Hydrocapitalism: 'French' Hydraulics in France, North Africa, and beyond. Social Studies of Science 42 (4): 591-615. doi:10.1177/0306312712443018.

Pro Bono Publico. 1887. “The Beterverwagting Flooding,” Daily Chronicle, 9 February. Georgetown, British Guiana.

Pulido, L. 1996. Introduction: Environmental Racism. Urban Geography 17 (5): 377-79. doi:10.2747/0272-3638.17.5.377.

Rabe, S.G. 2005. U.S. Intervention in British Guiana: A Cold War Story. Chapel Hill: University of North Carolina Press.

Radcliffe, S.A. 2017. "Decolonising Geographical Knowledges." Transactions of the Institute of British Geographers 42(3):329-33.

Ramraj, R. 2001. "The Population Geography of Guyana: Historical Perspectives and Demographic Trends.” Caribbean Geography 12(2):111-16.

Ranganathan, M. 2015. Storm Drains as Assemblages: The Political Ecology of Flood Risk in Post-Colonial Bangalore. Antipode 47(5): 1300-1320.

Rasmussen, K.S. 2011. "Foucault's Genealogy of Racism." Theory, Culture \& Society 28(5):34-51.

Ratepayer. 1886. "Plaisance Village," Daily Chronicle, 2 February. Georgetown, British Guiana.

Reclus, E. 1876. The Universal Geography, Vol. XIX: Amazonia and La Plata. London: J.S. Virtue \& Co. Ltd. 
"Report of a Commission of Inquiry into the Causes of a Disturbance Which Occurred at Skeldon on the $13^{\text {th }}$ of February 1957, and the Action Taken by the Police in Connection Therewith." Printed for the Government of British Guiana by the Daily Chronicle.

Rice Farmers Committee. 1953. British Guiana. Report of the Rice Farmers (Security of Tenure) Committee.

Richardson, B.C. 1970. The Rice Culture of Coastal Guyana: A Study in Location and Livelihood. PhD Dissertation, Geography, University of Wisconsin.

Richardson, B.C. 1972. “Guyana's 'Green Revolution': Social and Ecological Problems in an Agricultural Development Programme.” Caribbean Quarterly 18(1):14-23.

Richardson, B.C. 1973. "Spatial Determinants of Rural Livelihood in Coastal Guyana." The Professional Geographer 25(4):363-68.

Richardson, B.C. 1977. "Plantation and Village in Coastal Guyana, 1887-1969: Conflict or Complementarity?" Journal of Historical Geography 3(4):349-62.

Richardson, B.C. 1987. Men, Water, and Mudflats in Coastal Guyana. Resource Management and Optimization 5(1-4): 213-236.

Richardson, B.C. 1988. “Guyana.” Pp. 683-87 in Artificial Structures and Shorelines, edited by H. J. Walker. Boston, MA: Kluwer Academic Publishers.

Rodin, J. 2014. The Resilience Dividend: Being Strong in a World Where Things Go Wrong. New York: Public Affairs.

Rodney, W. 1970. A History of the Upper Guinea Coast, 1545-1800. London: Monthly Review Press.

Rodney, W. 1972. Tanzanian Ujamaa and Scientific Socialism. African Review, 1(4), 6176.

Rodney, W. 1981a. A History of the Guyanese Working People, 1881-1905. Baltimore: Johns Hopkins University Press.

Rodney, W. 1981b. "Guyana: The Making of the Labour Force." Race \& Class 22(4):331-52.

Rodney, W. 1981c. "People's Power, No Dictator." Latin American Perspectives 8(1):64-78. 
Rodney, W. 1981d. "Plantation Society in Guyana." Review (Fernand Braudel Center) 4 (4): 643-666.

Rodway, J. 1893. Handbook of British Guiana. Georgetown, British Guiana: The Columbian Exposition Literary Committee of the Royal Agricultural and Commercial Society.

Rodway, J. 1912. Guiana: British, Dutch, and French. London: T. Fisher Unwin.

Sanders, A. 1972. Amerindians in Guyana: A minority group in a multi-ethnic society. Caribbean Studies 12(2): 31-51.

Sanders, A. 1976. American Indian or West Indian: The Case of the Coastal Amerindians of Guyana. Caribbean Studies 16(2): 117-144.

Schuetze, T. and L. Chelleri. 2011. "Climate Adaptive Urban Planning and Design with Water in Dutch Polders." Water Science and Technology 64(3):722-30.

Scott, J.C. 1999. Seeing Like a State: How Certain Schemes to Improve the Human Condition Have Failed. New Haven: Yale University Press.

Sellars, S. 2010. "Hakim Bey: Repopulating the Temporary Autonomous Zone." Journal for the Study of Radicalism 4(2): 83-108.

Shahabuddeen, M. 1983. From Plantocracy to Nationalisation: A Profile of Sugar in Guyana. Turkeyen, Guyana: University of Guyana.

Shaw, A.B. 1987. "An Analysis of the Rainfall Regimes on the Coastal Region of Guyana." Journal of Climatology 7(3):291-302.

Shaw, W.S., R.D.K. Herman, and G.R. Dobbs. 2006. "Encountering Indigeneity: ReImagining and Decolonizing Geography." Geografiska Annaler. Series B, Human Geography 88(3):267-76.

Shrubsole, D. 2007. From Structures to Sustainability: A History of Flood Management Strategies in Canada. International Journal of Emergency Management 4 (2): 183.

Singhroy, V. 1998. "Monitoring and Mapping Areas Affected by Water Control Projects in Coastal Guyana." Pp. 81-91 in Hydrology in the Humid Tropic Environment IAHS Publ. no 253. Kingston, Jamaica.

Smith, N. 2008. Uneven Development: Natural, Capital, and the Production of Space, $3^{\text {rd }}$ Edition. Athens, GA: University of Georgia Press. 
Smith, R.T. 1964. Capital, Saving, and Credit in Peasant Societies. London: George Allen and Unwin Ltd.

Springer, S. 2012. “Anarchism! What Geography Still Ought to Be.” Antipode 44(5): 1605-1624.

Springer, S. 2013a. "Anarchism and Geography: A Brief Genealogy of Anarchist Geographies." Geography Compass 7(1): 46-60.

Springer, S. 2013b. "Violent Accumulation: A Postanarchist Critique in Neoliberalizing Cambodia." Annals of the Association of American Geographers 103(3): 608-626.

Springer, S. 2014. "Human Geography without Hierarchy." Progress in Human Geography 38(3): 402-419.

Springer, S., A. Ince, J. Pickerill, G. Brown, and A.J. Barker. 2012. "Reanimating Anarchist Geographies: A New Burst of Colour." Antipode 44(5): 1591-1604.

Standing, G. and F. Sukdeo. 1977. Labour Migration and Development in Guyana. International Labor Review 116: 303-13.

Stoler, A.L. 2008a. Along the Archival Grain: Epistemic Anxieties and Colonial Common Sense. Princeton, NJ: Princeton University Press.

Stoler, A.L. 2008b. Imperial Debris: Reflections on Ruins and Ruination. Cultural Anthropology, 23(2), 191-219. http://doi.org/10.1111/j.1548-1360.2008.00007.x

Stoler, A. L. 2016. Duress: Imperial Durabilities in Our Times. Durham, NC: Duke University Press.

Strachan, A. J. 1980. "Water Control in Guyana." Geography 65(4):297-304.

Sundberg, J. 2014. "Decolonizing Posthumanist Geographies." Cultural Geographies 21(1):33-47.

Tadaki, M., J. Salmond, R. Le Heron, and G. Brierley. 2012. Nature, Culture, and the Work of Physical Geography. Transactions of the Institute of British Geographers 37 (4): 547-62. doi:10.1111/j.1475-5661.2011.00495.x.

Taylor, M. 2015. The Political Ecology of Climate Change Adaptation: Livelihoods, Agrarian Change, and the Conflicts of Development. London: Routledge.

TeBrake, William H. 2002. "Taming the Waterwolf: Hydraulic Engineering and Water Management in the Netherlands During the Middle Ages." Technology and Culture 43(3):475-99. 
The Invisible Committee. 2017. Now. https://theanarchistlibrary.org/library/the-invisiblecommitte-now.pdf

Thom, E. 2011. Wretchedness in the Land of Many Waters: Locating Coastal Flooding within the Post-Colonial Political Economy of Guyana. Master's Thesis, Syracuse University, Syracuse, NY.

Thomas, C.Y. 1984. Plantations, Peasants, and State: A Study of the Mode of Sugar Production in Guyana. Los Angeles: Center for Afro-American Studies, University of California.

Thompson, A. and J. Bendik-Keymer (eds.) 2012. Ethical Adaptation to Climate Change: Human Virtues of the Future. Boston: MIT Press.

Thompson, A.O. 1987. Colonialism and Underdevelopment in Guyana, 1580-1803. Bridgetown, Barbados: Carib Research \& Publications.

Tierney, K. 2014. The Social Roots of Risk: Producing Disasters, Promoting Resilience. Palo Alto, CA: Stanford University Press.

Trollope, A. 1859. The West Indies and the Spanish Main. London: Chapman \& Hall.

Truth. 1887. "Sparendaam and Plaisance," Daily Chronicle, 9 February. Georgetown, British Guiana.

Tsing, A. 2005. Friction: An Ethnography of Global Connection. Princeton: Princeton University Press.

Turner, M.D. 2014. "Political Ecology I: An Alliance with Resilience?" Progress in Human Geography 38(4): 616-623.

Van den Bel, M., L. Hulsman, and L. Wagenaar, eds. 2014. The Voyages of Adriaan Van Berkel to Guiana: Amerindian-Dutch Relationships in $17^{\text {th }}$ Century Guyana. Leiden: Sidestone Press.

Van Schoubroek, F. 2010. The Remarkable History of Polder Systems in The Netherlands. FAO White Paper. http://www.fao.org/fileadmin/templates/giahs/PDF/Dutch-PolderSystem 2010.pdf

Vaughn, S.E. 2012. "Reconstructing the Citizen: Disaster, Citizenship, and Expertise in Racial Guyana." Critique of Anthropology 32(4):359-87. 
Vaughn, S.E. 2017. Disappearing Mangroves: The Epistemic Politics of Climate Adaptation in Guyana. Cultural Anthropology 32 (2): 242-68. doi:10.14506/ca32.2.07.

Veramallay, A.I. 1976. “An Evaluation of Water Resource Developments in Guyana: With Application to Selected Drainage and Irrigation Projects." PhD Dissertation, Department of Economics, Iowa State University.

Vining, J.W. 1977. "Presettlement Planning in Guyana." Geographical Review 67(4):469-80.

Viotti da Costa, E. 1997. Crowns of Glory, Tears of Blood: The Demerara Slave Rebellion of 1823. Oxford: Oxford University Press.

Wagner, M.J. 1977. "Rum, Policy, and the Portuguese: Or, the Maintenance of Elite Supremacy in Post-Emancipation British Guiana." Canadian Review of Sociology/Revue Canadienne de Sociologie 14(4):406-16.

Wakefield, S. 2018. "Infrastructures of Liberal Life : From Modernity and Progress to Resilience and Ruins.” Geography Compass doi:10.1111/gec3.12377.

Wald, N. 2014. “Anarchist Particpatory Development: A Possible New Framework?" Development and Change 46(4): 618-643.

Walker, B. and D. Salt. 2012. Resilience Practice: Building Capacity to Absorb Disturbance and Maintain Function. Washington, D.C.: Island Press.

Walker, J. and M. Cooper. 2011. Genealogies of Resilience: From Systems Ecology to the Political Economy of Crisis Adaptation. Security Dialogue 42(2): 143-160.

Washburn, Alexandros. 2013. The Nature of Urban Design: A New York Perspective on Resilience. Washington, D.C.: Island Press.

Watts, Michael. 1983. "Hazards and Crisis: A Political Economy of Drought and Famine in Northern Nigeria." Antipode 15(1): 24-34.

Watts, M. 2015. Now and Then: The Origins of Political Ecology and the Rebirth of Adaptation as a Form of Thought. In The Routledge Handbook of Political Ecology, 19-50, edited by Tom Perrault, Gavin Bridge, and James McCarthy. New York and London: Routledge.

Welsh, M. 2014. Resilience and responsibility: governing uncertainty in a complex world. The Geographical Journal 180(1): 15-26. 
Wesselink, A.J. 2007. Flood Safety in the Netherlands: The Dutch Response to Hurricane Katrina. Technology in Society 29 (2): 239-47.

White, D.F. and G. Kossoff. 2007. "Anarchism, Libertarianism and Environmentalism: Anti-Authoritarian Thought and the Search for Self-Organizing Societies." In The SAGE Handbook of Environment and Society, edited by Jules Pretty, Andy Ball, Ted Benton, Julia Guivant, David R. Lee, David Orr, Max Pfeffer, and Hugh Ward. London: SAGE Publications.

Whitaker, James Andrew. 2016. "Amerindians in the Eighteenth Century Plantation System of the Guianas." Tipiti: Journal of the Society for the Anthropology of Lowland South America 14(1):30-43.

Whitehead, N.L. 1988. Lords of the Tiger Spirit: A History of the Caribs in Colonial Venezuela and Guyana, 1498-1820. Providence: Foris Publications.

Whitehead, N.L. 1990. Carib Ethnic Soldiering in Venezuela, the Guianas, and the Antilles, 1492-1820. Ethnohistory 37(4): 357-385.

Williams, E. 1944. Capitalism and Slavery. Chapel Hill, NC: University of North Carolina Press.

Williams, P. and L. Johnson-Bhola. 2009. An Investigation into the Causes and Consequences of Coastal Flooding in Guyana. In Global and Caribbean Vulnerability: Environment, Economy, and Society at Risk, McGregor, D., D. Dodman, and D. Barker (eds), 74-99. Kingston: University of the West Indies Press

Williams, Z. 2017. "Crookrite Savannah flood addressed with urgency," Department of Public Information, Guyana. http://gina.gov.gy/cookrite-savannah-floodaddressed-with-urgency/

Wilson, B.M. 2002. "Critically Understanding Race-Connected Practices: A Reading of W.E.B. Du Bois and Richard Wright." The Professional Geographer 54(1): 3141.

Winner, L. 1986. The Whale and the Reactor: A Search for Limits in an Age of High Technology. Chicago: University of Chicago Press.

Wisner, B., P. Blaikie, T. Cannon, and I. Davis. 2004. At Risk: Natural Hazards, People's Vulnerability, and Disasters. New York: Routledge.

Young, A. 1955. Approaches to Local Self-Government in British Guiana. London: Longman's Green. 


\section{APPENDICES \\ APPENDIX A - LIST OF ARCHIVAL SOURCES}

Note: Directly citable items such as books, pamphlets, and newspaper articles obtained through the archives are listed in the references.

The Walter Rodney National Archives - Georgetown, Guyana

$\mathrm{AC} 8 / 42$

$\mathrm{AC} 8 / 43$

The National Archives - London, United Kingdom

\begin{tabular}{|c|c|c|}
\hline Colonial Office & CO $111 / 683 / 5$ & CO $111 / 713 / 8$ \\
\hline CO 111/1 & CO $111 / 688 / 5$ & CO $111 / 715 / 2$ \\
\hline CO $111 / 3$ & CO $111 / 688 / 8$ & CO $111 / 715 / 3$ \\
\hline CO $111 / 380$ & CO 111/688/9 & CO 111/720/8 \\
\hline CO $111 / 426$ & CO 111/693/1 & CO 111/720/9 \\
\hline CO $111 / 466$ & CO 111/694/5 & CO $111 / 724 / 3$ \\
\hline CO $111 / 483$ & CO 111/694/7 & CO 111/726/5 \\
\hline CO 111/491 & CO 111/694/8 & CO $111 / 727 / 1$ \\
\hline CO 111/641 & CO 111/695/8 & CO $111 / 727 / 2$ \\
\hline CO $111 / 642$ & CO 111/701/6 & CO $111 / 730 / 4$ \\
\hline CO $111 / 650 / 5$ & CO 111/701/7 & CO $111 / 730 / 6$ \\
\hline CO 111/661 & CO 111/702/1 & CO $111 / 737 / 6$ \\
\hline CO 111/671/11 & CO $111 / 702 / 2$ & CO $111 / 740 / 6$ \\
\hline CO 111/675/4 & CO 111/707/7 & CO 111/746/4 \\
\hline CO $111 / 680 / 10$ & CO 111/707/8 & CO $111 / 747 / 7$ \\
\hline
\end{tabular}




\begin{tabular}{|c|c|c|}
\hline CO $111 / 751 / 15$ & CO $111 / 785 / 5$ & CO $111 / 817 / 3$ \\
\hline CO 111/751/16 & CO $111 / 785 / 6$ & CO $111 / 817 / 4$ \\
\hline CO 111/751/17 & CO $111 / 785 / 7$ & CO $111 / 823 / 5$ \\
\hline CO 111/759/10 & CO $111 / 785 / 8$ & CO $318 / 444 / 58$ \\
\hline CO 111/761/4 & CO 111/785/9 & CO 950/626 \\
\hline CO $111 / 763 / 3$ & CO $111 / 786 / 1$ & CO 950/738 \\
\hline CO 111/766/5 & CO 111/786/2 & CO 1031/169 \\
\hline CO 111/769/1 & CO $111 / 786 / 3$ & CO 1031/162 \\
\hline CO $111 / 773 / 8$ & CO $111 / 786 / 4$ & CO 1031/170 \\
\hline CO 111/773/9 & CO $111 / 801 / 2$ & CO 1031/171 \\
\hline CO 111/773/10 & CO $111 / 801 / 3$ & CO 1031/995 \\
\hline CO $111 / 774 / 7$ & CO 111/801/4 & CO $1031 / 1444$ \\
\hline CO 111/774/9 & CO $111 / 801 / 5$ & CO $1031 / 1449$ \\
\hline CO $111 / 777 / 18$ & CO $111 / 810 / 5$ & CO $1031 / 2425$ \\
\hline CO 111/777/19 & CO $111 / 816 / 2$ & CO $1031 / 3468$ \\
\hline CO $111 / 778 / 22$ & CO $111 / 816 / 4$ & CO $1031 / 3469$ \\
\hline CO 111/779/1 & CO $111 / 816 / 6$ & CO $1031 / 3471$ \\
\hline CO 111/784/11 & CO $111 / 816 / 7$ & CO $1031 / 3472$ \\
\hline CO $111 / 785 / 2$ & CO $111 / 816 / 8$ & CO $1031 / 3473$ \\
\hline CO $111 / 785 / 3$ & CO $111 / 817 / 1$ & CO $1031 / 4567$ \\
\hline CO $111 / 785 / 4$ & CO $111 / 817 / 2$ & CO $1031 / 4568$ \\
\hline
\end{tabular}


CO 1069/355

Foreign and

Commonwealth Office

DO 200/200

DO 200/201

DO $200 / 203$

\section{HM Treasury}

T 161/1106/4

T 161/1106/5

T 161/1106/6

Overseas Development

OD 50/52

OD 50/53 


\section{Interview Questions and Probes}

Q1. Tell me about some experiences you've had with flooding in your neighborhood/village/community.

- When did the flood(s) occur?

- For how long did it/they last?

- What was/were the cause(s) of the flood(s)?

- Why do you think this area was impacted?

- Was this area impacted more than others? Why/why not?

- Did you do anything to lessen the impacts you felt? What did you do/why not?

Q2. Do you feel that your race/ethnicity was a factor in how you experienced the flood? How so/why not?

Q3. Do you think there are any historical factors that lead to the flooding or that shaped your experience of it? What are they?

- Do you think other governments/parties would have handled it differently? How so/why not?

Q4. What do you think should be done to reduce flooding in the future?

- Do you think this can be done? Why/why not?

- Are there any specific programs or agencies that might help? 
VITA

\section{JOSHUA MICHAEL MULLENITE}

Born, Hollywood, FL

2010-2011

A.A., Anthropology

Santa Fe College

Gainesville, FL

2011-2013

B.A., Sociology/Anthropology

Florida International University

Miami, FL

2013-2017

MA, Global and Sociocultural Studies

Florida International University

Miami, FL

2013-2017

Graduate Teaching Assistant

Florida International University

Miami, FL

2016-2018

Doctoral Candidate

Florida International University

Miami, FL

\section{SELECTED PUBLICATIONS AND PRESENTATIONS}

Mullenite, J. Forthcoming. "Infrastructure and Authoritarian Nationalism in the "Land of Waters": A Genealogy of Water Control in Guyana." Annals of the American Association of Geographers 109(2) doi:10.1080/24694452.2018.1490635

Mullenite, J. 2018. “"A Mild Despotism of Sugar': Race and the Political Economy of Flooding in British Guiana," American Association of Geographers' Annual Meeting, April 10-14, New Orleans, FL.

Mullenite, J. with A Collective of Anarchist Geographers. 2017. "Beyond Electoralism: Reflections on Anarchy, Populism, and the Crisis of Electoral Politics." ACME: An International Journal of Critical Geographies 16(4): 607-642

Mullenite, J. 2017. “Can Climate Change Adaptation be a Desirable Goal?” Human Geography 10(2): 87-94 
Mullenite, J. 2017. "Race and the Political Economy of Flood Management in Coastal British Guiana," Florida Society of the Social Sciences $12^{\text {th }}$ Annual Conference, April 15, University of Florida, Gainesville, FL.

Mullenite, J. 2017 "In the Shell of Colonialism: An Anarchist Political Ecology of Flood Management in Guyana," American Association of Geographers' Annual Meeting, April 5-9, Boston MA.

Mullenite, J. 2016. "Resilience, Political Ecology, and Power: Convergences, Divergences, and the Potential for a Postanarchist Geographical Imagination." Geography Compass 10(9): 378-388 doi:10.1111/gec3.12279

Mullenite, J. 2016. "Review of Principles for Building Resilience: Sustaining Ecosystem Services in Social-ecological Systems edited by Biggs, Schlüter, and Schoon." Environment \& Society: Advances in Research 7: 134-136. doi:10.3167/ares.2016.070108

Mullenite, J. 2016. "Book Review: Understanding Poverty and the Environment: Analytical Frameworks and Approaches by Fiona Nunan." Progress in Development Studies 16(4): 370-371 doi:10.1177/1464993416657631

Mullenite, J. 2016. “The Promise of Resilience: Imagining Radical Socioecological Futures," Dimensions of Political Ecology, February 25-27, University of Kentucky, Lexington, KY.

Mullenite, J. 2015. "Historical Repetition and Development Narratives in Guyana's Coastal Drainage and Irrigation System." Consilience: The Journal of Sustainable Development 13(2): 126-139 doi:10.7916/D8PN95C6

Mullenite, J. 2015. "Book Review: The Political Ecology of the State: The Basis and the Evolution of Environmental Statehood by AAR Ioris." Journal of Ecological Anthropology 17: 54-56 doi:10.5038/2162-4593.17.1.8

Mullenite, J. 2015. "The Historical Political Ecology of Coastal Inundation in Guyana," Southeast Division of the Association of American Geographers' Annual Meeting, November 22-24, Pensacola, FL.

Mullenite, J. 2015. "The Changing Landscapes of Cold War Agricultural Development in Guyana," International Conference of Historical Geographers, July 5-10, London, United Kingdom.

Mullenite, J. 2015. "Tension, Anxiety, and Heterogeneity in Technical Assistance: The University of Florida and USAID in Guyana," Association of American Geographers' Annual Meeting, April 22-25, Chicago, IL. 